PNNL-18408

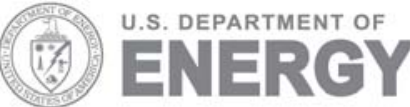

Prepared for the U.S. Department of Energy

under Contract DE-AC05-76RL01830

\title{
Characterization of Settler Tank and KW Container Sludge Simulants
}

CA Burns

M Luna

AJ Schmidt

May 2009

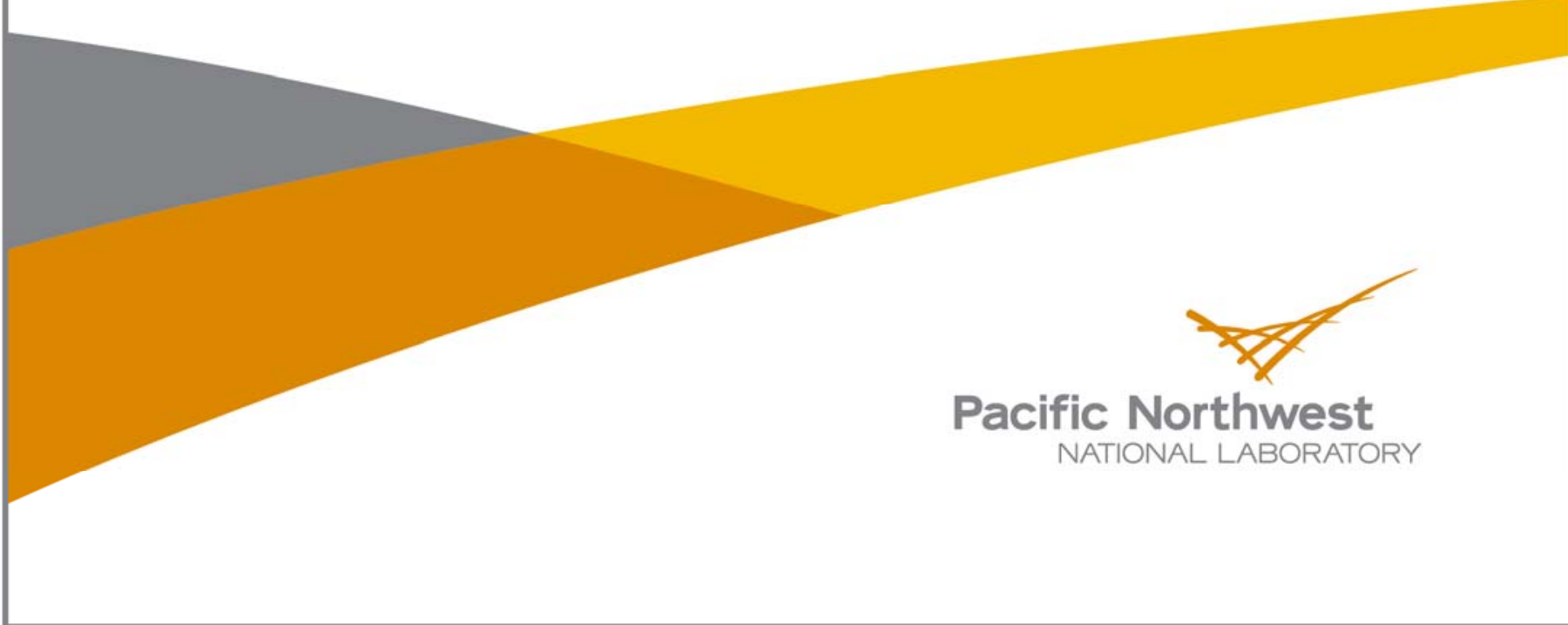




\title{
DISCLAIMER
}

This report was prepared as an account of work sponsored by an agency of the United States Government. Neither the United States Government nor any agency thereof, nor Battelle Memorial Institute, nor any of their employees, makes any warranty, express or implied, or assumes any legal liability or responsibility for the accuracy, completeness, or usefulness of any information, apparatus, product, or process disclosed, or represents that its use would not infringe privately owned rights. Reference herein to any specific commercial product, process, or service by trade name, trademark, manufacturer, or otherwise does not necessarily constitute or imply its endorsement, recommendation, or favoring by the United States Government or any agency thereof, or Battelle Memorial Institute. The views and opinions of authors expressed herein do not necessarily state or reflect those of the United States Government or any agency thereof.

\author{
PACIFIC NORTHWEST NATIONAL LABORATORY \\ operated by \\ BATTELLE \\ for the \\ UNITED STATES DEPARTMENT OF ENERGY \\ under Contract DE-ACO5-76RL01830
}

Printed in the United States of America
Available to DOE and DOE contractors from the
Office of Scientific and Technical Information,
P.O. Box 62, Oak Ridge, TN 37831-0062;
ph: (865) 576-8401
fax: (865) 5765728
email: reports@adonis.osti.gov

\footnotetext{
Available to the public from the National Technical Information Service, U.S. Department of Commerce, 5285 Port Royal Rd., Springfield, VA 22161 ph: (800) 553-6847 fax: (703) 605-6900

email: orders@nits.fedworld.gov online ordering: http://www.ntis.gov/ordering.htm
} 


\section{Characterization of Settler Tank and KW Container Sludge Simulants}

CA Burns

M Luna

AJ Schmidt

May 2009

Prepared for

the U.S. Department of Energy

under Contract DE-AC05-76RL01830

Pacific Northwest National Laboratory

Richland, Washington 99352 


\begin{abstract}
The Sludge Treatment Project (STP), managed by CH2M Hill Plateau Remediation Company (CHPRC) has specified base formulations for non-radioactive sludge simulants for use in the development and testing of equipment for sludge sampling, retrieval, transport, and processing. In general, the simulant formulations are based on the average or design-basis physical and chemical properties obtained by characterizing sludge samples. The simulants include surrogates for uranium metal, uranium oxides (agglomerates and fine particulate), and the predominant chemical phases (iron and aluminum hydroxides, sand). Specific surrogate components were selected to match the nominal particle-size distribution and particle-density data obtained from sludge sample analysis.

Under contract to CHPRC, Pacific Northwest National Laboratory (PNNL) has performed physical and rheological characterization of simulants, and the results are reported here. Two base simulant types (dry) were prepared by STP staff at the Maintenance and Storage Facility and received by PNNL on February 12, 2009: Settler Tank Simulant and KW Container Sludge Simulant. The objectives of this simulant characterization effort were to provide baseline characterization data on simulants being used by STP for process development and equipment testing and provide a high-level comparison of the simulant characteristics to the targets used to formulate the simulants.
\end{abstract}





\section{Summary}

The Sludge Treatment Project (STP), managed by CH2M Hill Plateau Remediation Company (CHPRC), has specified base formulations for non-radioactive sludge simulants for use in developing and testing equipment for sludge sampling, retrieval, transport, and processing. The simulant compositions are documented in a memorandum that is included in Appendix A. ${ }^{(a)}$ In general, the simulant formulations are based on the average or design-basis physical and chemical properties obtained through characterization of actual sludge samples. The simulants include surrogates for uranium metal, uranium oxides (agglomerates and fine particulate), and the predominant chemical phases (iron and aluminum hydroxides, sand). Specific surrogate components were selected to match the nominal particle-size distribution (PSD) and particle-density data obtained from sludge sample analysis.

Under contract to CHPRC, Pacific Northwest National Laboratory (PNNL) has performed physical and rheological characterization of simulants, and the results are reported here. Two base simulant types (dry) were prepared by STP staff at the Maintenance and Storage Facility (MASF) and received by PNNL on February 12, 2009: settler tank simulant, and KW container sludge simulant. To support rheological characterization, the KW container simulant was provided as several discrete samples: whole PSD and simulant sieved at $500 \mu \mathrm{m}$. Settler sludge simulant only contains particles less than $600 \mu \mathrm{m}$; therefore, size fractionation of this simulant was not required.

The objectives of this simulant characterization effort were:

1) Provide baseline characterization data on simulants being used by STP for process development and equipment testing.

2) Provide a high-level comparison of the simulant characteristics to the targets used to formulate the simulants.

3) New data will be acquired from characterization of actual sludge samples during the second half of FY 2009 (sludge from KW containers 240, 250, 260, and 220) and in FY 2010 (sludge from settler tanks and KW container 210). If significant discrepancies in properties are found between the simulant and new sludge samples, and these differences are important to the STP equipment testing objectives, then base simulant formulations may be adjusted.

The simulant characterization approach used by PNNL was based on the physical and rheological characterization approach described within the Sampling Analysis Plan (SAP) for sludge in the KW engineered containers (Baker 2009). Thus, this characterization work also serves as an opportunity to refine and optimize the sample handling and rheological characterization techniques that will be used with actual sludge samples

\section{S.1 Settler-Sludge-Simulant Characterization}

Tables S.1 summarizes the PNNL characterization results obtained from the settler simulant sample (ST-A) provided by STP in February 2009 and compares the results to other simulants and data. The

(a) GT MacLean. 2008. K Basin Sludge Simulants, Letter Report, From GT MacLean (Fluor Government Group) to R Lokken, August 7, 2008, Fluor Government Group, Richland, WA (See Attachment A). 
properties and parameters are compared to the values established in Schmidt and Zacher (2007) (Composition and Technical Basis for K Basin settler sludge simulant for Inspection Retrieval and Pump Testing) and incorporated into the MacLean memorandum (Attachment A). ${ }^{\text {(a) }}$ In Schmidt and Zacher (2007), the simulant was formulated based on data (i.e., composition and PSD) from KE and KW canister sludge samples (i.e., predominant source streams to the settler tanks). Settled density was also identified as a key parameter during the simulant development, and an iron hydroxide slurry was added to control this parameter. Targets for shear strength and yield stress were not specified in Schmidt and Zacher (2007); however, the simulant sample prepared in 2007 exhibited a relatively high shear strength relative to actual sludge samples (Plys and Schmidt 2004.

Characterization of settler simulant (ST A) (Table S.1) demonstrates that it adequately meets most targets established during simulant development. However, the measured shear strength does not bound the maximum values measured for all sludge samples (i.e., including KE Canister sludge samples with particles greater than $250 \mu \mathrm{m}$ ) and is lower than the settler simulant prepared in 2007 (using essentially the same formulation). With granular sludges, shear-strength measurements are highly sensitive to sample history, vessel geometry, and water content. Differences in handling (i.e., higher water content of ST-A) and characterization techniques likely contributed to the differences in the characterization results between settler simulant prepared in 2009 and 2007.

Larger batches of settler simulant and KW container simulant have been prepared by CHPRC and loaded into large-scale mock-up test systems and 55-gal drums at MASF. In these configurations, the CHPRC operators and test engineers have observed very high strengths in the simulant (qualitative observations). These observations are consistent with predictions of the behavior of materials with significant granularity under a lithostatic head (i.e., contribution of fractional forces to shear strength).

The PSD of Sample ST-A meets the target values established in Schmidt and Zacher (2007). To match the established PSD targets, mass-weighted PSDs of the individual simulant components were summed (values in Table S.1), and PSD measurements of the resulting simulant were not performed in 2007. The PSDs of the individual simulant components used for the ST-A simulant are known based on vendor data, sieving, and PSD measurement preformed on individual components. Due to sample size limitations (very small), sub-sampling challenges, and instrument limitations (i.e., use of optical lightscattering technique for samples with complex composition, size, and density), to obtain a representative PSD (by volume), multiple sub-samples need to be analyzed and averaged.

(a) GT MacLean. 2008. K Basin Sludge Simulants, Letter Report, From GT MacLean (Fluor Government Group) to R Lokken, August 7, 2008, Fluor Government Group, Richland, WA (See Attachment A). 
Table S.1. Settler Sludge Simulant Characterization Summary and Comparison

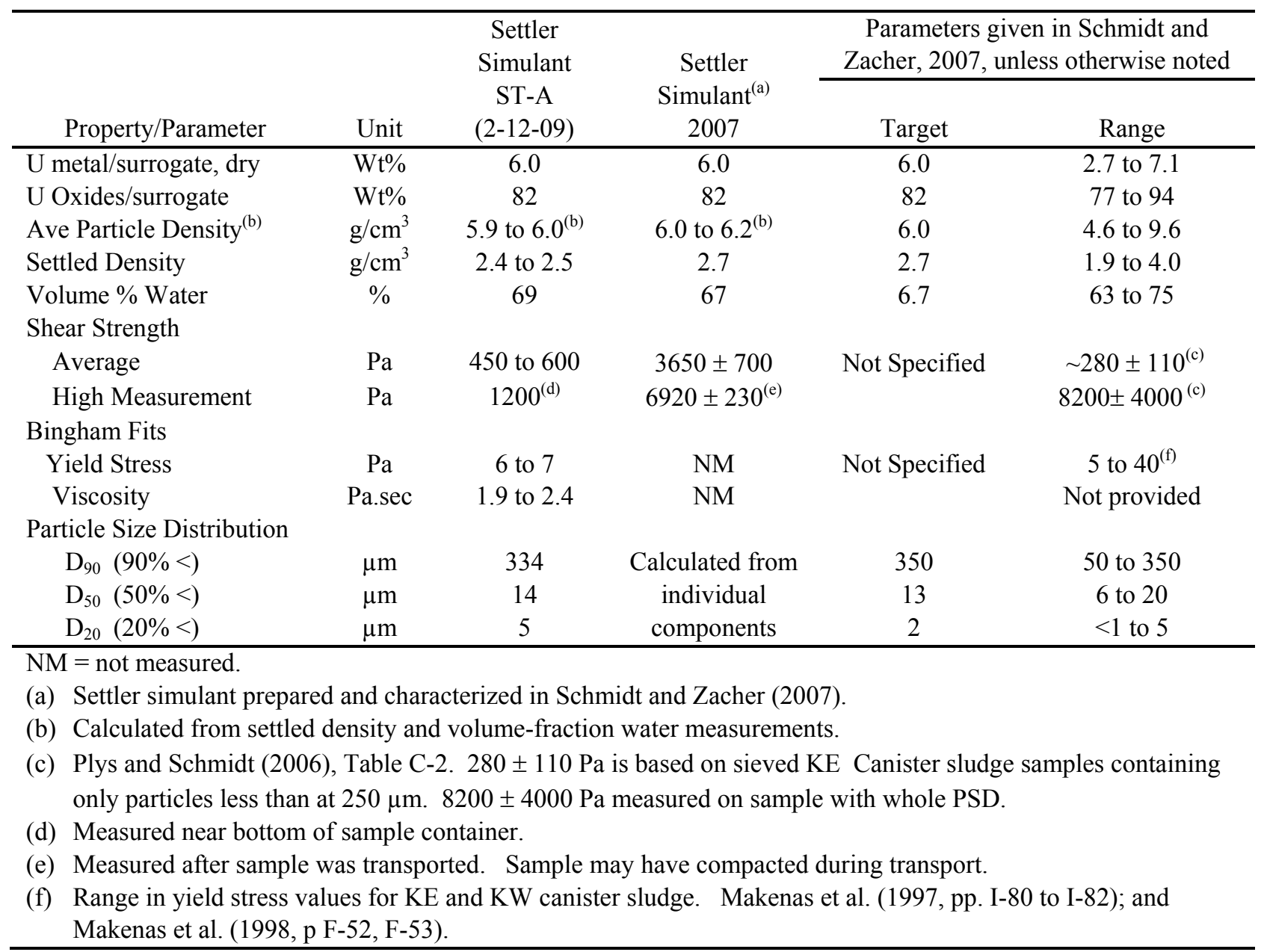

\section{S.2 KW Container Sludge Simulant Characterization}

Table S.2 summarizes the PNNL characterization results obtained from the KW container simulant samples, KW-A (whole) and KW-B $(<500 \mu \mathrm{m})$, provided by STP in February 2009 and compares the results to targets (MacLean memorandum) and the Sludge Databook (Schmidt 2009) parameters. The KW container simulant was formulated to represent the full sludge PSD of sludge within engineered containers 210 and 220 (i.e., maximum size, up to $6350 \mu \mathrm{m}$ [ $1 / 4 \mathrm{in}$.$] ). Therefore, consistent with the SAP$ for KW containerized sludge (Baker 2009), and to better conform to instrumentation limits/recommendations on particle size, much of the rheological characterization of the KW container sludge simulant was performed on size-segregated simulant (KW-B). Particles greater than $500 \mu \mathrm{m}$ (approximately $25 \mathrm{wt} \%$ of whole sample) were removed by passing the simulant through a sieve. Because of the sieving, characterization results from the KW-B sample $(<500 \mu \mathrm{m})$ are not directly comparable to targets established for the "whole" simulant.

Comparison of the KW container simulant to Sludge Databook (Schmidt 2009) parameters (Table S.2) shows that the simulant was formulated based on design-basis values for the KW originating (container 210 and 220) sludge. Because the composition of the safety-basis KW-originating sludge approaches that of settler sludge (and exceeds it with respect to uranium metal); design-basis values were 
used to provide a distinct mobilization/retrieval challenge (i.e., includes significant concentrations of other components: iron hydroxides, aggregate, sand, aluminum hydroxide vs. a simulant with very high concentration of uranium oxide surrogate, such as cerium oxide).

For most parameters of interest to sludge retrieval/mobilization equipment, the results from laboratory characterization of KW container simulants meet or exceed targets established based on existing characterization data. Relatively high shear-strength values were measured for the KW-B sample (sieved to remove all particle greater than $500 \mu \mathrm{m}$ ). The settled density and volume fraction solids are higher (conservative for mobilization and retrieval) than safety-basis $\mathrm{KW}$ originating container sludge. The PSD appears to be low for the coarsest particle-size material (100 to $500 \mu \mathrm{m})$.

\section{Conclusions and Recommendations}

The simulant characterization results provide base data to document and better understand simulant properties and behavior.

Challenges encountered during characterization of the simulants (PSD and rheological characterization) need to be considered and addressed before initiating rheological characterization of the new samples of containerized sludge being taken in 2009. Measurement set-up conditions and sample geometry must be defined and standardized.

STP equipment testing activities conducted at MASF (documented in STP project records) have shown that the settler sludge and KW container sludge simulants present appreciable challenges to mobilization and retrieval approaches. However, it is not possible for a single simulant to bound all parameters of interest. For each specific process equipment test, careful consideration of each application must be used to guide the selection of simulants and potential modification to the base simulant formulations. 
Table S.2. KW Container Sludge Simulant Characterization Summary and Comparison

\begin{tabular}{|c|c|c|c|c|c|c|}
\hline \multirow[b]{3}{*}{ Property/Parameter } & \multirow[b]{3}{*}{ Unit } & \multicolumn{2}{|c|}{ KW Container Samples ${ }^{(a)}$} & \multicolumn{3}{|c|}{$\begin{array}{l}\text { Parameters from MacLean, }{ }^{(b)} \\
\text { (unless otherwise noted) }\end{array}$} \\
\hline & & \multirow{2}{*}{$\begin{array}{l}<500 \mu \mathrm{m} \\
\mathrm{KW}-\mathrm{B}\end{array}$} & \multirow{2}{*}{$\begin{array}{l}\text { Whole } \\
\text { KW-A }\end{array}$} & \multirow{2}{*}{$\begin{array}{l}\text { Target } \\
\text { Whole }\end{array}$} & \multicolumn{2}{|c|}{$\begin{array}{c}\text { Databook KW Con } \\
210 \& 220^{(\mathrm{c})} \\
\end{array}$} \\
\hline & & & & & Design & Safety \\
\hline $\begin{array}{l}\text { Fraction of Whole Sample } \\
\text { Mass }\end{array}$ & $\mathrm{Wt} \%$ & 75 & 100 & 100 & 100 & 100 \\
\hline U metal/surrogate, dry & $\mathrm{Wt} \%$ & $<1{\text { (Est })^{(\mathrm{d})}}$ & 3.6 & 3.6 & 3.6 & 7.7 \\
\hline U Oxides/surrogate, dry & $\mathrm{Wt} \%$ & $\sim 40{\text { (Est })^{(\mathrm{d})}}$ & 35.1 & 35.1 & $\sim 35^{(\mathrm{e})}$ & $58^{(\mathrm{e})}$ \\
\hline Ave Particle Density & $\mathrm{g} / \mathrm{cm}^{3}$ & $4.7(\text { calc })^{(\mathrm{f})}$ & $3.7(\text { calc })^{(\mathrm{f})}$ & 3.29 & 3.3 & 4.1 \\
\hline Settled Density & $\mathrm{g} / \mathrm{cm}^{3}$ & 2.4 & 2.4 & Not Specified & 1.6 & 1.8 \\
\hline Volume \% Water & $\%$ & 62 & 48 & Not Specified & 74 & 74 \\
\hline \multicolumn{7}{|l|}{ Shear Strength } \\
\hline$<500 \mu \mathrm{m}$ & $\mathrm{Pa}$ & 800 to 2400 & NM & Not Specified & \multicolumn{2}{|c|}{$\sim 500^{(\mathrm{g})}$} \\
\hline High Measurement & $\mathrm{Pa}$ & 5700 & NM & & \multicolumn{2}{|c|}{$8200^{(\mathrm{g})}$} \\
\hline \multicolumn{7}{|l|}{ Bingham Fits } \\
\hline Yield Stress & $\mathrm{Pa}$ & 21 to 27 & NM & Not Specified & \multirow{2}{*}{\multicolumn{2}{|c|}{$\begin{array}{l}1 \text { to } 40^{(\mathrm{h})} \\
\text { Not provided }\end{array}$}} \\
\hline Viscosity & Pa.sec & 1.6 to 3.4 & NM & & & \\
\hline \multicolumn{7}{|l|}{ Particle-Size Distribution } \\
\hline $\mathrm{D}_{90}(90 \%<)$ & $\mu \mathrm{m}$ & 345 & NM & 2200 & \multicolumn{2}{|c|}{$+/-20 \%$} \\
\hline $\mathrm{D}_{50}(50 \%<)$ & $\mu \mathrm{m}$ & 25 & NM & 27 & \multicolumn{2}{|c|}{$+/-20 \%$} \\
\hline $\mathrm{D}_{10}(10 \%<)$ & $\mu \mathrm{m}$ & 3 & NM & 2 & \multicolumn{2}{|c|}{$+/-20 \%$} \\
\hline \multicolumn{7}{|l|}{$\mathrm{NM}=$ not measured } \\
\hline $\begin{array}{l}\text { (a) See Attachment A. Wl } \\
\text { (b) Simulant composition } \\
\text { (c) Schmidt (2009), Table } \\
\text { (d) Estimated by simulant } \\
\text { (e) Assumes U oxides are } \\
\text { (f) Calculated from settled } \\
\text { (g) Plys and Schmidt (200 } \\
\text { than at } 250 \mu \mathrm{m} .8200 \\
\text { (h) Range in yield stress va } \\
\text { Makenas et al. (1997, }\end{array}$ & $\begin{array}{l}\text { le PSD } \\
\text { ovided i } \\
2 . \\
\text { ake-up i } \\
1 / 3 \mathrm{UO}_{2} \\
\text { lensity a } \\
\text { Table } \\
\text { measur } \\
\text { des for K } \\
\text { I- } 80 \text { to }\end{array}$ & $\begin{array}{l}\text { le }(\mathrm{KW}-\mathrm{A}) \text { and } \\
\text { cLean memora } \\
\text { achment A. } \\
\mathrm{U}_{4} \mathrm{O}_{9}+1 / 3 \mathrm{UO} \\
\text { bume fraction } \\
500 \mathrm{~Pa} \text { is basec } \\
\text { sample with v } \\
\text { oor and } \mathrm{KE} / \mathrm{K} \\
\text {; and Makenas }\end{array}$ & $\begin{array}{l}2 \mathrm{O} \text { mixture ( } \\
\text { r measureme } \\
\text { sieved sludge } \\
\text { e PSD. } \\
\text { inister sludge } \\
\text { (1998), pp F }\end{array}$ & $\begin{array}{l}\text { nole basis mixtu } \\
\text { amples containir } \\
\text { Makenas et al. (1 } \\
2, \text { F-53. }\end{array}$ & $\begin{array}{l}\text { only part } \\
6 \text {, pp I-1 }\end{array}$ & $\begin{array}{l}\text { es less } \\
\text { [-15); }\end{array}$ \\
\hline
\end{tabular}

\section{References}

Baker RB, JA Pottmeyer, JL Westcott, AJ Schmidt and TL Welsh. 2009. Quality Assurance Project Plan/Sampling and Analysis Plan for Sludge in the KW Engineered Containers, KBC-33786, Rev. 1, CH2MHill Plateau Remediation Company, Richland, Washington

Makenas BJ, TL Welsh, RB Baker, DR Hansen, and GR Golcar. 1996. Analysis of Sludge form Hanford K East Basin Floor and Weasel Pit, HNF-SP-1182, Westinghouse Hanford Company, Richland, Washington.

Makenas BJ, TL Welsh, RB Baker, EW Hoppe, AJ Schmidt, J Abrefah, JM Tingey, PR Bredt, and GR Golcar. 1997. Analysis of Sludge from Hanford K East Basin Canisters, HNF-SP-1201, Rev. 0, Westinghouse Hanford Company, Richland, Washington. 
Makenas TL Welsh, RB Baker, GR Golcar, PR Bredt, AJ Schmidt, and JM Tingey. 1998. Analysis of Sludge from Hanford K West Basin Canisters, HNF-1728 Rev. 0, Fluor Hanford, Inc., Richland, Washington.

Plys MG and AJ Schmidt. 2006 Supporting Basis for SNF Project Technical Databook. SNF-7765 Rev. 3, Fluor Hanford, Inc. Richland, Washington.

Schmidt AJ. 2009. Spent Nuclear Fuel Project Technical Databook. HNF-SD-SNF-TI-015, Vol. 2, "Sludge," Rev. 14, Fluor Hanford, Inc. Richland, Washington.

Schmidt AJ and AH Zacher. 2007. Composition and Technical Basis for K Basin Settler Sludge Simulant for Inspection, Retrieval and Pump Testing. PNNL-16619, Rev 1., Pacific Northwest National Laboratory, Richland Washington. 


\section{Acronyms}

$\begin{array}{ll}\text { CHPRC } & \text { CH2M Hill Plateau Remediation Company } \\ \text { KW-B } & \text { KW Basin } \\ \text { MASF } & \text { Maintenance and Storage Facility } \\ \text { NIST } & \text { National Institute of Standards and Technology } \\ \text { PNNL } & \text { Pacific Northwest National Laboratory } \\ \text { PSD } & \text { particle-size distribution } \\ \text { SAP } & \text { Sampling Analysis Plan } \\ \text { STDEV } & \text { standard deviation } \\ \text { STP } & \text { Sludge Treatment Project }\end{array}$





\section{Contents}

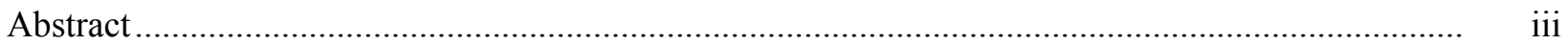

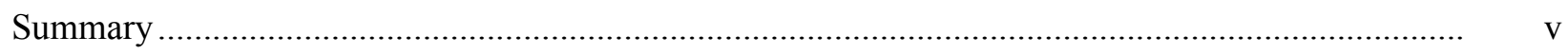

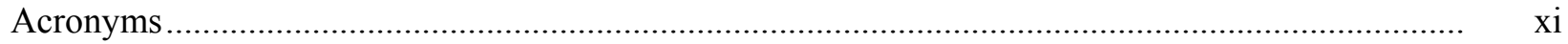

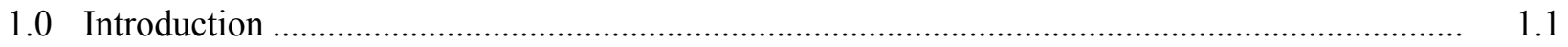

2.0 Simulant Samples and Initial Preparations ................................................................. 2.1

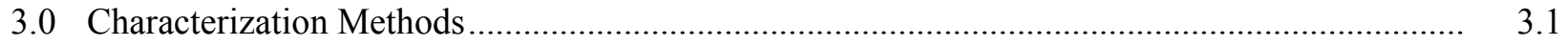

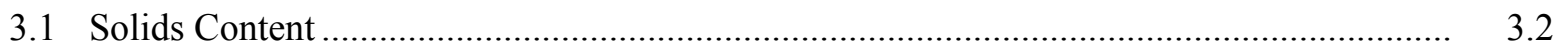

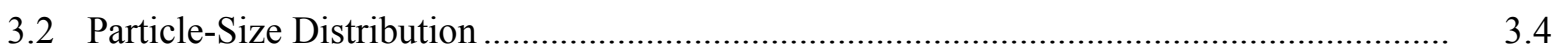

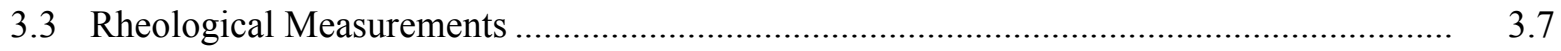

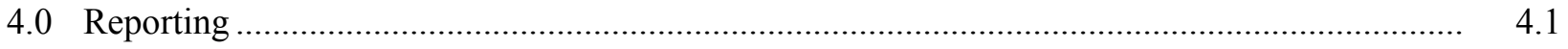

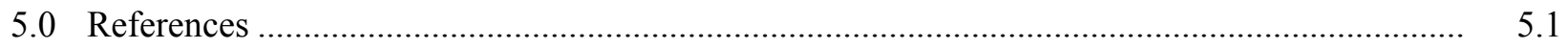

Appendix A: Simulant Material Provided to Pacific Northwest National Laboratory ....................... A.1

Appendix B: Particle-Size Distribution Data ............................................................................ B.

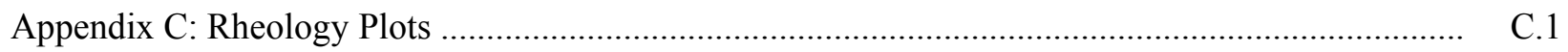

\section{Figures}

3.1. Graphical Depiction of Approach to Simulant Characterization ........................................ 3.2

3.2. Cumulative Percentage of Particles as a Function of Particles Size for both Settler and KB

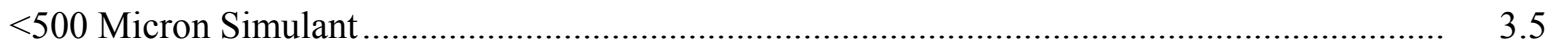

3.3. Percent in Range as a Function of Particle Size in Microns for a) Black Bars, Settler Simulant and b) Blue Bars KW-B <500 Micron Simulant .................................................... 3.6

3.4. Typical Stress-Versus-Time Profile for a Shear Vane at Constant Shear Rate ........................ 3.8

3.5. Shear Stress Versus Shear Rate of Settler Simulant ......................................................... 3.11

3.6. Viscosity Versus Shear Rate Obtained for the Settler Simulant shown 3.5 ........................... 3.12

\section{Tables}

1.1. Settler Tank and KW Container Sludge Simulant Compositions .......................................... 1.2

2.1. Simulant Received for Characterization .......................................................................... 2.2

3.1. Summary of Simulant Characterization Measurements and Calculations ................................ 3.3

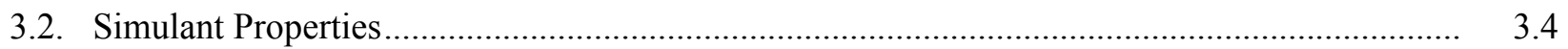

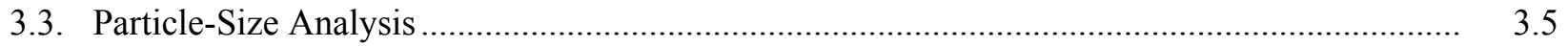

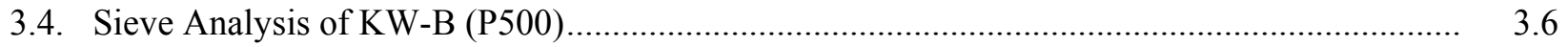

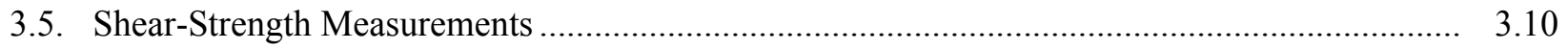

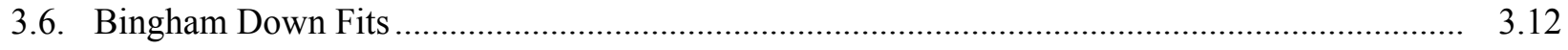




\subsection{Introduction}

The Sludge Treatment Project (STP), managed by CH2M Hill Plateau Remediation Company (CHPRC), has specified base formulations for non-radioactive sludge simulants to use in developing and testing equipment for sludge sampling, retrieval, transport, and processing. Under contract to CHPRC, Pacific Northwest National Laboratory (PNNL) has performed physical and rheological characterization of simulants, and the results are reported here.

The STP base simulant compositions are designed to represent three primary K Basin sludge streams and are documented in a memorandum ${ }^{(a)}$ (MacLean 2008) that is included in Appendix A.

The simulant formulations are:

1. KE Basin containerized sludge simulant (KE container simulant), to represent sludge originating in the KE Basin pits and floor that now resides in KW containers 240, 250, and 260

2. KW Basin container sludge simulant ( $\mathrm{KW}$ container simulant), to represent sludge originating from the KWest pit and floors that currently (or in the future) resides in KW containers 210 and 220

3. Settler sludge simulant, to represent KW settler tank sludge that will be recovered into KW container 230.

The first two formulations are similar; however, the KW sludge in containers 210 and 220 is expected to exhibit a higher uranium content (metal and oxide) than the KE Basin originating sludge contained within containers 240, 250, and 260. For equipment testing, the STP has elected to use the more aggressive KW container simulant to conservatively represent both the KW and KE Basin container sludge. Therefore, for simulant characterization reported here, only the latter two of the base simulant types (KW container and settler tank simulant) were characterized.

In addition to the summary formulation provided in the MacLean memorandum (Appendix A), a more detailed description of the technical basis for the settler tank simulant is provided in Schmidt and Zacher (2007). This simulant was formulated based on examination of design- and safety-basis mixtures of KE and KW Canister sludge samples (i.e., the predominant source stream to the settler tanks). The $\mathrm{KW}$ container simulant formulation is based on the average- or design-basis physical and chemical properties of the source streams that make up the sludge in containers 210 and 220 (source streams makeup described in the Sludge Technical Databook [Schmidt 2009]).

The simulants include surrogates for uranium metal, uranium oxides (agglomerates and fine particulate), and the predominant chemical phases (iron and aluminum hydroxides, sand). Specific surrogate components were selected to match the nominal particle-size distribution (PSD) and particle density data obtained from sludge sample analysis. Table 1.1 provides a summary of the simulant compositions. Additional details on the simulant make-up are provided in Appendix A.

(a) GT MacLean. 2008. K Basin Sludge Simulants. Letter Report from GT MacLean (Fluor Government Group) to R Lokken, August 7, 2008, Fluor Government Group, Richland, Washington. 
Table 1.1. Settler Tank and KW Container Sludge Simulant Compositions

\begin{tabular}{|c|c|c|c|}
\hline \multirow[b]{2}{*}{$\begin{array}{c}\text { Sludge Component } \\
\text { Represented } \\
\end{array}$} & \multirow[b]{2}{*}{$\begin{array}{c}\text { Simulant Component } \\
\text { Used }\end{array}$} & \multicolumn{2}{|c|}{ Simulant (Dry Basis) } \\
\hline & & $\begin{array}{c}\text { Settler Tank, } \\
\text { Wt } \%\end{array}$ & $\begin{array}{c}\text { KW Container, } \\
\mathrm{Wt} \%\end{array}$ \\
\hline Uranium metal & Tungsten particles & 6 & 3.6 \\
\hline $\begin{array}{l}\text { Uranium oxide } \\
\text { agglomerates }\end{array}$ & Steel grit & 14 & 4.2 \\
\hline $\begin{array}{l}\text { Uranium Oxide } \\
\text { fine particles }\end{array}$ & Cerium oxide & 68 & 30.9 \\
\hline $\begin{array}{l}\text { Aluminum hydroxides } \\
\text { and blow sand }\end{array}$ & Flyash & 11 & 0 \\
\hline Non U larger particles & Aggregate (rocks) & 0 & 16.9 \\
\hline Blow sand & Sand & 0 & 14.7 \\
\hline \multirow[t]{2}{*}{ Iron Phases } & $\begin{array}{l}\text { Iron hydroxide (added } \\
\text { as a slurry) }\end{array}$ & 1 & 0 \\
\hline & Iron oxide hydroxide & 0 & 21.9 \\
\hline Aluminum Phases & Gibbsite, $\mathrm{Al}(\mathrm{OH})_{3}$ & 0 & 7.8 \\
\hline Total & & $100 \%$ & $100 \%$ \\
\hline
\end{tabular}

Setter tank sludge is expected to exhibit a much higher uranium total concentration than the KE/KW container sludge, and as shown in Table 1.1, the compositions of these simulant are very different. Also, while the KW container simulant contains particles up to $6350 \mu \mathrm{m}$, the settler sludge simulant only contains particles less than $600 \mu \mathrm{m}$. Therefore, these two simulants represent distinct challenges for the development and testing of sludge handling equipment.

To support design and testing goals of the STP, the physical properties and rheology of the KW containerized sludge and settler sludge simulants have been characterized. This report outlines the approach that was used to characterize these simulants and documents the results of the characterization efforts. The simulant characterization approach used by PNNL was based on the physical and rheological characterization approach described within the Sampling Analysis Plan (SAP) for sludge in the KW engineered containers (Baker 2009). Thus, this characterization work also serves as an opportunity to refine and optimize the sample handling and rheological characterization techniques that will be used with actual sludge samples.

New data will be acquired from characterization of actual sludge samples during the second half of FY 2009 (sludge from KW containers 240, 250, 260 and 220) and in FY 2010 (sludge from settler tanks and $\mathrm{KW}$ container 210). If significant discrepancies in properties are found between the simulant and new sludge samples, and these differences are important to the STP equipment testing objectives, then base simulant formulations may be adjusted. 


\subsection{Simulant Samples and Initial Preparations}

Simulants were prepared by STP staff at the Maintenance and Storage Facility (MASF). Each simulant component was extracted from the vendor-supplied container with a small shovel or spatula, weighed, and then added to a sample bottle. All weight measurements were performed to the nearest 0.1 gram, using a calibrated balance.

For the settler sludge simulant, $\sim 600 \mathrm{~g}$ of the dry simulant components were provided in a single container. Iron hydroxide slurry, $13 \mathrm{wt} \% \mathrm{Fe}(\mathrm{OH})_{3}$ in water (Noah Technologies Corporation), was provided in a separate container with instructions on the quantity to add to complete the simulant.

STP staff prepared two equal 600 -g batches of KW container sludge sample. One batch was then subjected to dry sieving (through a \#35 [500 micron] sieve using mechanical agitation for approximately 15 minutes) to create the "fine" and "coarse" KW container simulant fractions. These two sub-fractions were placed into separate bottles.

The simulants (Table 2.1) were received by PNNL on February 12, 2009, under a chain of custody (included in Attachment A). At PNNL, the simulant components were mixed, an excess of water was added, and they were allowed to settle for 24 hours. After this settling period was complete, excess water was decanted from the top of the settled solids. This process of mixing, settling (for 24-hours), and decanting excess water was repeated two more times. To avoid loss of fine particles in the mixed simulant slurry as a result of repeated decanting operations, any solid particles removed with the decant liquid were recovered and returned to the simulant test mixture. Because of the large range in particle sizes and densities of the individual sludge components, dispersions of these materials may be subject to significant size and density segregation. Dilute suspensions of the slurry are likely to yield stratification of simulant components based on the overall particle/aggregate settling velocities. However, well-mixed thickened sludge simulant has sufficient shear strength to uniformly suspend dense particles, and concentration-hindered particle settling also limits the degree of component segregation. For this reason, sub-sampling the settled and thickened slurry provides the most representative sampling.

This process of dry weighing and combining components before adding water is consistent with the manner in which large batches of simulant are prepared by STP during testing at MASF; however, due to scale differences, the process may have some inherent differences, particularly in the area of hydration of the solids. 
Table 2.1. Simulant Received for Characterization

\begin{tabular}{|c|c|c|}
\hline $\begin{array}{c}\text { Sample } \\
\text { Identification }\end{array}$ & $\begin{array}{l}\text { Quantity } \\
\text { (Dry Basis) }\end{array}$ & Description \\
\hline ST-A & $600 \mathrm{~g}$ & $\begin{array}{l}\text { KW Settler Simulant (note PNNL combined dry } \mathrm{Fe}(\mathrm{OH})_{3} \\
\text { slurry with dry components) }\end{array}$ \\
\hline KW-A & $600 \mathrm{~g}$ & KW Container Simulant, whole PSD \\
\hline KW-B (M500) & $449.2 \mathrm{~g}$ & $\begin{array}{l}\text { Size fractionated KW Container Simulant, }<500 \mu \mathrm{m} \\
\text { (Note: unless otherwise noted, KW-B (M500) is referred } \\
\text { to as KW-B in this report) }\end{array}$ \\
\hline KW-B (P500) & $148.8 \mathrm{~g}$ & $\begin{array}{l}\text { Size fractionated KW Container Simulant, }-6350 \text {, } \\
+500 \mu \mathrm{m}\end{array}$ \\
\hline
\end{tabular}




\subsection{Characterization Methods}

A graphical depiction of how the simulant samples were handled and the approach for simulant characterization used at PNNL are given in Figure 3.1. The KW container simulant was formulated to represent the full sludge PSD of sludge (i.e., maximum size, up to $6350 \mu \mathrm{m}[1 / 4 \mathrm{in}$.]). Therefore, consistent with the SAP for KW containerized sludge (Baker 2009), and to better conform to instrumentation limits/recommendations on particle size, as shown in Figure 3.1, much of the rheological characterization of the KW container sludge simulant was performed on size-segregated simulant (KW-B). Particles greater than $500 \mu \mathrm{m}$ (approximately $25 \mathrm{wt} \%$ of whole sample), were removed by passing the simulant through a sieve.

The physical and rheological properties of the simulants were determined according to PNNL technical procedure RPL-Colloid-02 Rev. 1, "Measurement of Physical and Rheological Properties of Solutions, Slurries, and Sludges." The simulants prepared as described in the preceding paragraphs were to be tested to determine the physical properties outlined in Table 3.1. The physical and rheological properties measured include settled density, solids content (both volume and weight fraction), settling rate, PSD, viscosity as a function of shear rate, and shear strength. The average particle density of the simulants was calculated from the simulant composition and particle density of the individual simulant components. It should be noted that due to difficulties in measuring the shear stress vs. shear rate, the proposed dilutions outlined in Table 3.1 were not attempted.

For the determination of settled density, settling rate, and volume fraction of both the water and solids, duplicate aliquots of the simulants were transferred into $100-\mathrm{mL}$ graduated cylinders, and the sediment volume was monitored as a function of time. The sediment volume is the volume from the bottom of the suspension column to the interface between the clear supernatant and the cloudy suspension. 


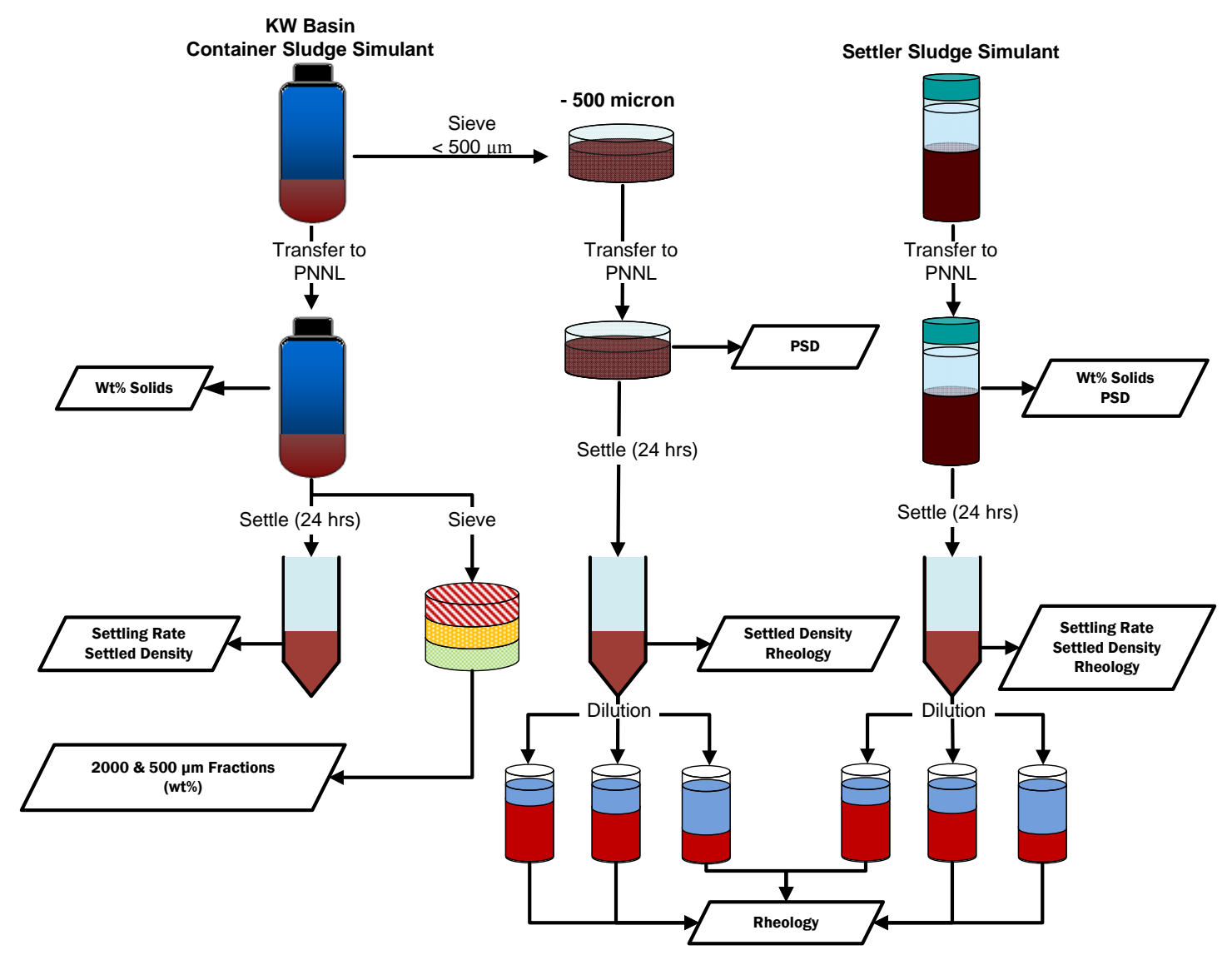

Figure 3.1. Graphical Depiction of Approach to Simulant Characterization

Under the force of gravity, the solids in the suspension sink to the bottom of the cylinder, forming a sludge layer and a clear supernatant layer. The final sediment-bed volume is measured after no significant change in the height of this sludge layer is observed over 4 hours. The volume percent settled solids is then determined by dividing the final sediment bed volume by the total volume of the slurry. The settling rate was determined on the dewatered simulant used for all tests outlined in Table 3.1.

\subsection{Solids Content}

The solids content was analyzed with a gravimetric method after oven drying at $105^{\circ} \mathrm{C}$. The procedure for using this method is PNNL Technical Procedure RPL-COLLOID-02 (Daniel 2007).

The solids content of a sample is the mass of the dried sample divided by the original mass of the settled sample. 
Table 3.1. Summary of Simulant Characterization Measurements and Calculations

\begin{tabular}{|c|c|}
\hline Property/Parameter & Measurement/Calculation Approach \\
\hline Settled Density & $\begin{array}{l}\text { Prep simulant with excess water; allow sludge to settle for } 24 \mathrm{hr} \text {; } \\
\text { measure volume and mass. }\end{array}$ \\
\hline $\begin{array}{l}\text { Wt } \% \text { Total Solids } \\
\text { (in settled sludge) }\end{array}$ & $\begin{array}{l}\text { Dry aliquot (known mass and volume) of as-settled sludge at } 105^{\circ} \mathrm{C} \text {, } \\
\text { measure mass, and record dry bulk volume. }\end{array}$ \\
\hline $\begin{array}{l}\text { Volume Fraction Water } \\
\text { (in settled sludge) }\end{array}$ & $\begin{array}{l}\text { Calculated from settled density and } \mathrm{wt} \% \text { solids. Assumption: all } \\
\text { mass loss during drying at } 105^{\circ} \mathrm{C} \text { is from loss of water. }\end{array}$ \\
\hline $\begin{array}{l}\text { Volume Fraction Solids } \\
\text { (in settled sludge) }\end{array}$ & Calculated from volume fraction water. \\
\hline Settling Rate & Graduated cylinder and stop watch. \\
\hline & Calculated from wt $\%$ solids and vol fraction solids. \\
\hline Average Particle Density & $\begin{array}{l}\text { Calculated from vendor/handbook data on simulant components and } \\
\text { simulant make up. }\end{array}$ \\
\hline \multirow{3}{*}{ Particle-Size Distribution } & Calculated from vendor data on components and simulant make up \\
\hline & $<500 \mu \mathrm{m}^{(\mathrm{a})}$-Particle size analyzer. \\
\hline & $\begin{array}{l}\text { Sieve }>500-\mu \mathrm{m} \text { sample using the following: Sieves } 4000 \mu \mathrm{m} \text {, } \\
2000 \mu \mathrm{m} \text {, and } 500 \mu \mathrm{m} \text { - dry mass of resulting three fractions. }\end{array}$ \\
\hline \multirow{3}{*}{$\begin{array}{l}\text { Viscosity vs Shear Rate, Shear } \\
\text { Stress vs. Shear Rate } \\
\text { (Rheograms) }\end{array}$} & $<500 \mu \mathrm{m}$ fraction ${ }^{(\mathrm{a})}$ \\
\hline & $\begin{array}{l}\text { Concentrations: as settled, } 75 \%, 50 \% \text {, and } 25 \% \text { volume ratio of as- } \\
\text { settled + water. }\end{array}$ \\
\hline & Rheology of each concentration was measured at $72^{\circ} \mathrm{F}$. \\
\hline Shear Strength & $\begin{array}{l}<500 \mu \mathrm{m} \text { fraction }{ }^{(\mathrm{a})}: \\
\text { Settled sludge } 24,48 \text { - to } 91 \text {-hour gel time, vane rheometer. }\end{array}$ \\
\hline
\end{tabular}

(a) Note: for settler sludge simulant, all particles are $<600 \mu \mathrm{m}$. Therefore, for these analyses, settler simulant will not be size fractionated.

A summary of the characterization data obtained is given in Table 3.2. 
Table 3.2. Simulant Properties

\begin{tabular}{|c|c|c|c|c|}
\hline Simulant & $\begin{array}{c}\text { ST-A } \\
\text { (settler) }\end{array}$ & $\begin{array}{c}\text { KW-B } \\
<500 \mu \mathrm{m}\end{array}$ & $\begin{array}{c}\mathrm{KW}-\mathrm{A} \\
\text { (complete KW) }\end{array}$ & Unit \\
\hline \multicolumn{5}{|l|}{ Property } \\
\hline Average Particle Density ${ }^{(a)}$ & 6.00 & 3.56 & 3.56 & $\mathrm{~g} / \mathrm{cm}^{3}$ \\
\hline Average Particle Density ${ }^{(b)}$ & 5.91 & nd & 3.74 & $\mathrm{~g} / \mathrm{cm}^{3}$ \\
\hline Settled sludge density, ${ }^{\left({ }^{2}\right)}$ ST- $A^{(\mathrm{f})}$ & 2.52 & insufficient sample & $2.41 \pm 0.01$ & $\mathrm{~g} / \mathrm{cm}^{3}$ \\
\hline Settled sludge density ${ }^{(\mathrm{g})}$ & $2.42 \pm 0.03$ & $2.38 \pm 0.05$ & nd & $\mathrm{g} / \mathrm{cm}^{3}$ \\
\hline Settling rate, First 24 hours & 0.17 & 0.04 & 0.09 & $\mathrm{~mL} / \mathrm{hr}$ \\
\hline $\mathrm{Wt} \%$ water $^{(\mathrm{e})}$ & $27.40 \pm 0.43$ & $25.51 \pm 0.16$ & $20.05 \pm 0.82$ & Percent \\
\hline Volume fraction water ${ }^{(b, c)}$ & 69.07 & 61.59 & 48.15 & Percent \\
\hline Shear strength $^{(b)}$ & & & nd & \\
\hline Mixed, $\sim 21 \mathrm{~h}$ gel time, middle ${ }^{(\mathrm{d})}$ & $491 \pm 36$ & $1719 \pm 580$ & & Pascal \\
\hline Mixed, $\sim 21 \mathrm{~h}$ gel time, bottom & 627 & 1597 & & Pascal \\
\hline Mixed, $48 \mathrm{~h}$ gel time, middle & 612 & $986 \pm 266$ & & Pascal \\
\hline Mixed, $91 \mathrm{~h}$ gel time, middle & 604 & $1519 \pm 34$ & & Pascal \\
\hline Mixed, $91 \mathrm{~h}$ gel time, & 1214 & 14 & & Pascal \\
\hline
\end{tabular}

(a) Calculated based on vendor-provided data.

(b) Based on measurements performed on simulant prepared in laboratory.

(c) Performed with Haake - RS600, $1.6 \mathrm{~cm}$ diameter by $1.6 \mathrm{~cm}$ height shear vane.

(d) Mean \pm STDEV of 2 (3 for St-A, $21 \mathrm{hr}$ ) measurements.

(e) Mean \pm STDEV of 2 measurements.

(f) Measurement (1) made on unused simulant.

(g) Duplicates measured on sample used for Rheology, KW-B measured on Rheology sample only. Note: these samples have been mixed and measured several times.

\subsection{Particle-Size Distribution}

The PSD of the "fines" (KW-B $<500 \mu \mathrm{m})$ fraction of the KW container simulant and the "whole" settler simulant (maximum particle size $\sim 600 \mu \mathrm{m}$ ) were measured using laser diffraction technology (Table 3.3 and Figure 3.2 and Figure 3.3). A Malvern Mastersizer 2000 equipped with a Hydro S dispersion unit was used to analyze samples, and software for the particle size analyzer calculates the PSD (i.e., fractional volume contribution versus particle diameter) from the light-scattering patterns using Mie scattering theory.

Particles with diameters between 0.02 and 1400 microns $(\mu \mathrm{m})$ can be analyzed by the instrument to determine the PSD of the simulants. However, because of the high density of some of the simulant components, large size particles (greater than $600 \mu \mathrm{m}$ ) were not introduced to the instrument.

The distribution of particles greater than $500 \mu \mathrm{m}$ for the $\mathrm{KW}$ simulant was determined by sieving methods, and results are also provided in Table 3.4.

Before conducting any simulant slurry particle-size measurements, the PSD of a National Institute of Standards and Technology (NIST)-traceable particle-size standard was measured. The standard consisted of polydispersed (in size) silica particles with diameters falling primarily between 10 and 100 microns. The result of this measurement was compared to the standard's certificate of analysis provided by NIST, and the acceptable performance of the size analyzer was confirmed. The Malvern Mastersizer 2000 requires the particle refractive index (RI) to calculate the particles size. In the case of complex simulants, such as those used in this study, a trial and error approach is used to determine the particle refractive 
index. It was determined that little change in the PSD was observed when using an RI of 2.2 (cerium oxide) -2.94 (ferric oxide hydroxide) with a particle-absorption index of 0 or 1 .

Table 3.3. Particle-Size Analysis

\begin{tabular}{cccc}
\hline & \multicolumn{3}{c}{ Cumulative Percent Less Than } \\
\cline { 2 - 4 } Size, $\mu \mathrm{m}$ & $\begin{array}{c}\text { Settler Simulant } \\
\text { ST-A }\end{array}$ & $\begin{array}{c}\text { KW-B (wet) } \\
<500 \mu \mathrm{m}\end{array}$ & $\begin{array}{c}\text { KW-B (dry) } \\
<500 \mu \mathrm{m}\end{array}$ \\
\hline 800 & 99.10 & 99.99 & 100 \\
600 & 97.07 & 98.42 & 99.94 \\
500 & 94.95 & 96.21 & 99.3 \\
250 & 88.23 & 84.86 & 95.8 \\
100 & 87.08 & 74.24 & 92.5 \\
40 & 84.01 & 59.30 & 80.2 \\
20 & 66.23 & 45.56 & 62.6 \\
10 & 38.00 & 29.83 & 41.6 \\
5 & 19.22 & 17.01 & 24.1 \\
2.5 & 9.60 & 3.03 & 12.2 \\
1 & 3.01 & 3.03 & 3.9 \\
0.5 & 0.69 & 0.73 & 0.985 \\
\hline
\end{tabular}

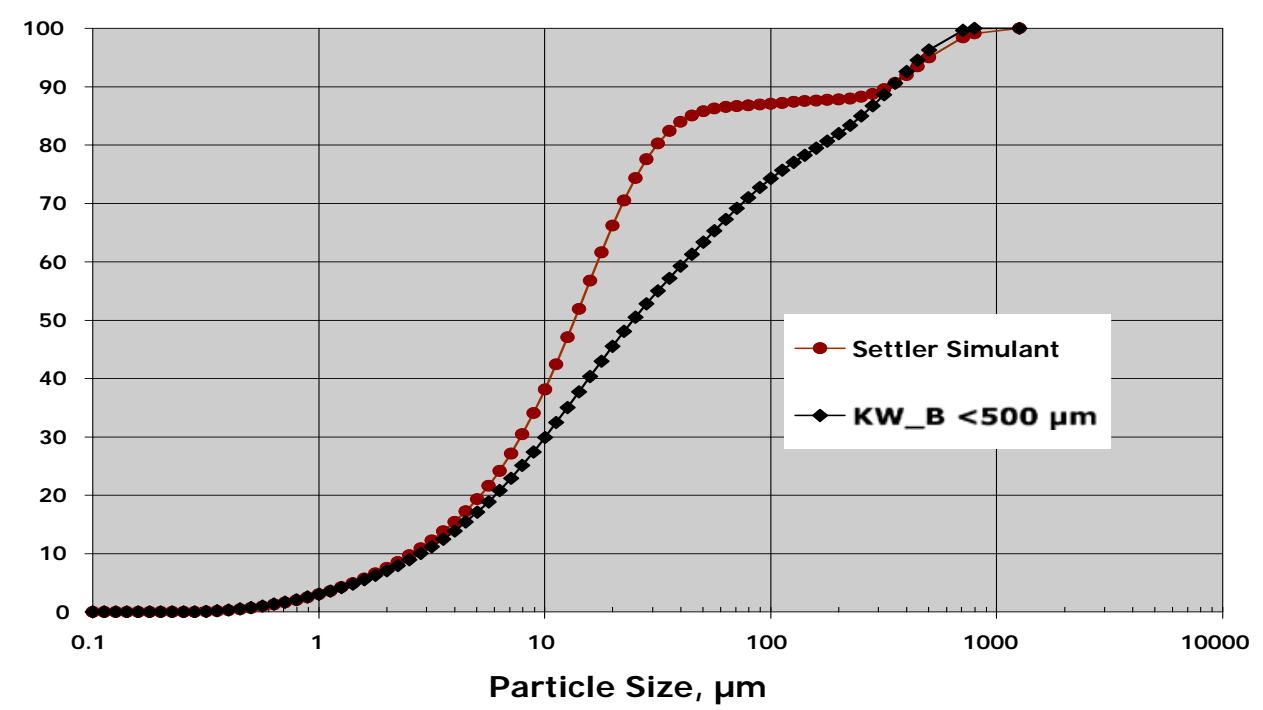

Figure 3.2. Cumulative Percentage of Particles as a Function of Particles Size for both Settler and KB $<500$ Micron Simulant 


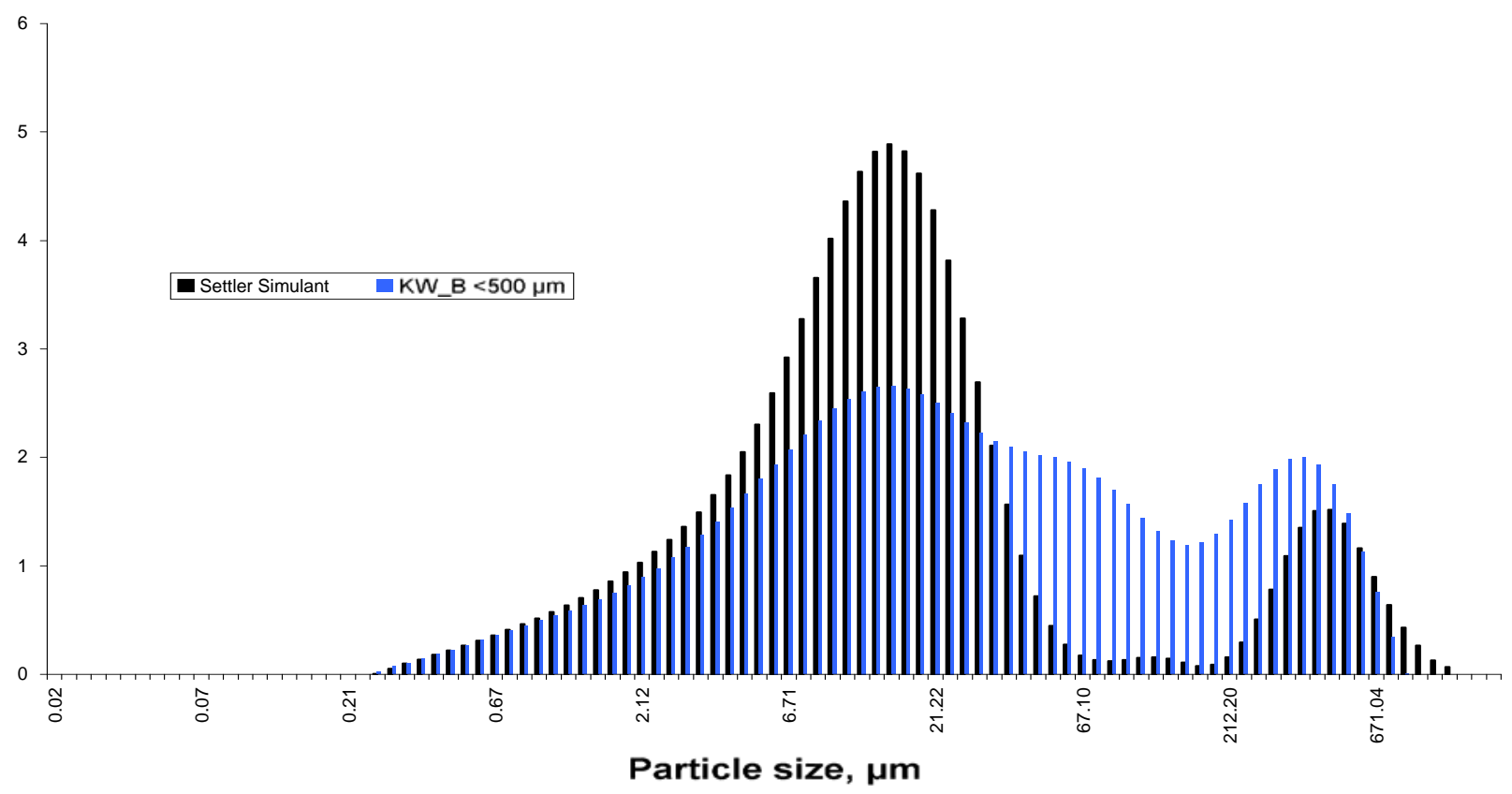

Figure 3.3. Percent in Range as a Function of Particle Size in Microns for a) Black Bars, Settler Simulant and b) Blue Bars KW-B $<500$ Micron Simulant

Table 3.4. Sieve Analysis of KW-B (P500)

\begin{tabular}{cc}
\hline $\begin{array}{c}\text { Sample Weight }(\mathrm{g}) \\
\text { Sieve } \\
\mu \mathrm{m}\end{array}$ & $\begin{array}{c}149.87 \\
\text { Cumulative } \\
\text { \% less than }\end{array}$ \\
\hline 4000 & 78.31 \\
2000 & 57.90 \\
1000 & 25.42 \\
500 & 0.31 \\
\hline
\end{tabular}

When measuring the particle size of simulant materials, small aliquots of the concentrated simulant dispersion $(<1 \mathrm{~mL})$ were diluted in deionized water in a variable-speed recirculator before taking the particle-size measurements (Hydro $\mathrm{S}$ dispersion unit). The dilution factor is determined by monitoring the amount of light passing through the diluted material - this is referred to as obscuration. Obscuration is a function of the amount of particles present and is used to determine the amount of material used for an analysis. Sufficient sample dilution to yield obscuration values of 5 to $20 \%$ are generally considered acceptable for size measurements, which corresponds to sample sizes in the range of $0.1 \mathrm{~g}$ (for fine/lessdense particles) to $2 \mathrm{~g}$ for larger/more-dense particles. Due to the presence of the cerium oxide and iron hydroxide in our simulants, very little sample was required to reach the maximum obscuration value of the instrument. Measurements were performed at a pump speed of $2000 \mathrm{rpm}$. Particle-size analyzers measure volume distributions and thus are highly dependent on the size of particles present, given that particle volume is proportional to the cubed root of its diameter. Particles that have the greatest impact on the volume distribution are also those that are the most difficult to sub-sample in complex, mixed simulants like those used in this study. This is well illustrated in the PSDs obtained for the settler simulant (ST-A) in Appendix B. For comparison purposes and to illustrate the relationship between 
particle size and volume, an example of the PSD transformed to number $\%$ has been included for each simulant.

Simulant samples were shaken before taking aliquots for PSD analysis. Measurements were made on samples with no additional chemical treatment apart from the sample dilution required to obtain acceptable obscuration values. To determine the stability of the particles with respect to mechanical forces, measurements of particle size before, during, and after the application of sonication were taken. The use of sonication helps verify that the simulant particles are well dispersed, and no particle agglomeration or breaking or particle settling occurs during particle-size measurements.

Measuring the particle size of the settler simulant proved challenging. Specifically, it was difficult to obtain a representative sample of the settler simulant that contained both the larger particles and the finer particles without creating a bias in the results. The heterogeneity of the simulant and the variability in the component density and size range made it very difficult to obtain a representative PSD of the settler simulant. Multiple sub-samples were measured, and the cumulative average PSD along with the individual averages of each aliquot are given in Appendix B. The results given in Table 3.3 and Figure 3.2 and Figure 3.3 are based on the average of all sub-samples (settler simulants, four aliquots, Appendix B). The PSDs obtained for both the settler simulant and the KW-B $<500$ micron compare well with the target distributions given in the memorandum (MacLean 2008) that is included in Appendix A. The PSDs given in Appendix B illustrate the difficulties encountered obtaining a representative sample for the settler simulant; this is due to the optical properties of the complex simulant and the sampling difficulties. The abundance of fine particles likely causes saturation of the optical detector before the larger particles are at a concentration that can be measured. This is illustrated in sub-samples where particles greater than 100 microns were not detected. To verify that representative PSDs of such simulants are captured, multiple sub-sampling is required.

Additional consideration is needed on dilution approaches that should be pursued for PSD measurements for complex simulants and actual sludge samples. The dispersion unit used in the hot cell at PNNL that will be used for actual $\mathrm{K}$ Basin sludge calls for a 10-fold reduction in sample size. This will increase the difficulties in obtaining a representative sample and capturing the larger, higher density particles.

\subsection{Rheological Measurements}

Shear strength is a semi-quantitative measure of the force required to move the sample and is dependent on sample history. Shear strength can be measured directly by slowly rotating a vane immersed in the sample material and recording the resulting torque as a function of time. The measured torque is converted to a shear stress by equations 3.1 and 3.2 .

$$
\tau=T / K
$$

where

$$
K=\frac{\pi D^{3}}{2}\left(\frac{H}{D}+\frac{1}{3}\right)
$$


where $\tau=$ calculated shear stress in Pascal

$\mathrm{T}=$ measured torque in Newton-meters

$\mathrm{K}=$ shear vane constant in cubic meters

$\mathrm{D}=$ shear vane diameter in meters

$\mathrm{H}=$ shear vane height in meters.

A typical stress/time profile is shown in Figure 3.4. The profile shows an initial linear region $\left(\tau_{\mathrm{y}}\right)$ followed by a nonlinear region, a stress maximum $\left(\tau_{\mathrm{s}}\right)$, and a stress decay region. The stress maximum is the transition between the visco-elastic and fully viscous flow. Shear strength is defined as the transition between these two flows and is measured at the stress maximum.

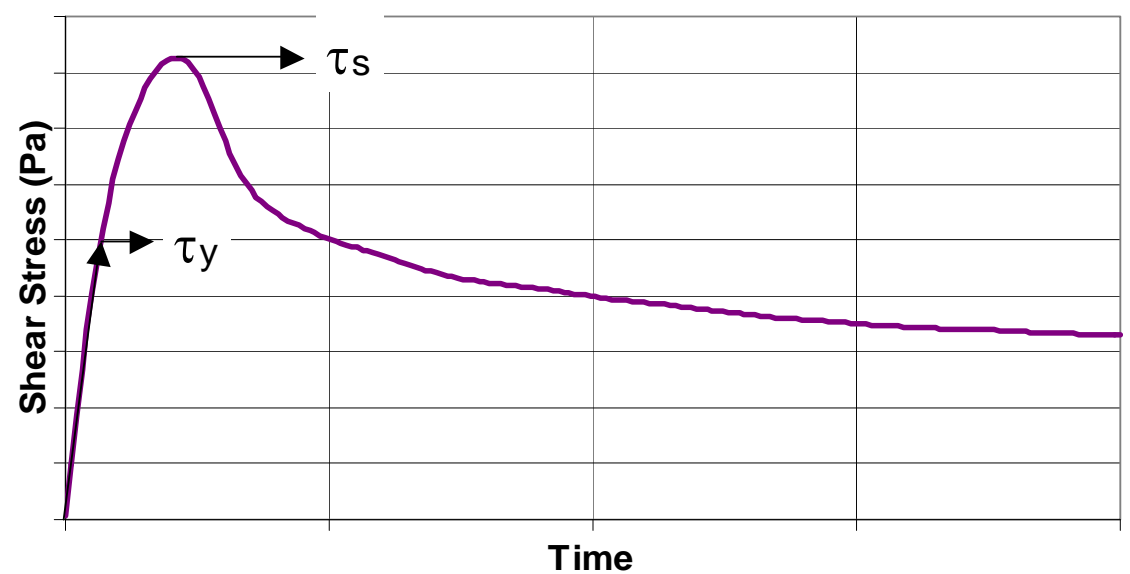

Figure 3.4. Typical Stress-Versus-Time Profile for a Shear Vane at Constant Shear Rate

In general, the test material should be saturated, fine grained, and homogeneous to provide reliable/consistent results from the shear vane test system. There are two primary force contributions to the torque measurement with the shear vane technique: 1) colloidal forces and 2) frictional forces. The colloidal forces will be dominant for slurries with smaller particles (generally under 1 to $10 \mu \mathrm{m}$ ). Frictional forces become important for slurries with large particles (generally greater than 50 microns). Friction will vary with the depth of the slurry and the test geometry of the sample container. The K Basin simulants and sludge contain both fine and larger grain materials, and frictional forces are expected to be a significant contributor to the shear-strength measurements.

Viscosity is determined by analyzing the flow curve. The flow curve was obtained on a rheometer where shear stress can be measured as a function of shear rate. The shear rate was ramped from 0 up to $1000 \mathrm{~s}^{-1}$ (or maximum obtainable shear rate for the tool) over a 5-minute period. The shear rate was held constant at $1000 \mathrm{~s}^{-1}$ (or maximum obtainable rate) for 1 minute and then ramped back down to $0 \mathrm{~s}^{-1}$ over another 5-minute period. Standard rheological models are used to fit the flow curves and determine the yield stress and viscosity of the material. The calibration was checked with certified viscosity standards to verify that the rheometer is operating within acceptable tolerance ranges.

A rheogram for a material with a yield stress has two portions to it. The first portion appears as a nearly vertical line beginning at the origin and running up the ordinate. This portion of the rheogram is 
recording the behavior of the material as it acts like a solid or gel. When sufficient force is transmitted to the material to break the gel or make it yield, the rheogram angles sharply to the right, and from then on, the behavior of the material as a fluid is recorded. The point in the curve at which the sample transfers from a solid or gel to a fluid is the yield point. The stress at this point measured in Pascals on the ordinate is the value of the yield stress. The viscosity is the slope of the curve after the material has yielded.

The shear-strength measurements of both the ST-A (settler simulant) and the KW-B simulants (less than $500 \mu \mathrm{m}$ ) are summarized in Table 3.5. The corresponding stress versus time profiles can be found in Appendix C. The shear strength was measured for gel times of 21, 48, and 91 hours for both simulants. The Haake RS 600 Rheometer was used to measure shear strengths. Measurements employed a shear vane tool (16 $\mathrm{mm}$ diameter by $16 \mathrm{~mm}$ height four-blade vane). Samples were measured in 250 -mL wideneck Nalgene bottles at two different measurement depths, the middle of the container and the bottom (1 times the vane diameter from container bottom). No temperature control was employed during shearstrength measurement.

From Table 3.5, we can see that measurements taken at the bottom of the settler simulant container as opposed to the middle exhibited greater shear strengths. These values were not included in the average value given in Table 3.2. The settler simulant appeared to have a gradient throughout the container, most probably because of particle settling and continued dewatering of the simulant. This behavior was not observed in the KW-B simulant. Both simulants were very difficult to mix and required considerable force to resuspend them between measurements.

It should be noted that the shear strength of the KW-B simulant more than doubled after fines (settled out of the water removed during dewatering, $<0.5 \mathrm{~g}$ ) were reintroduced into the container and mixed on the top. This observation is most likely due to vibration/packing effects of the simulant during partial mixing and has been reported here because of the magnitude of the change observed. The simulant was split into two equal parts to facilitate the performance of parallel experiments; both parts underwent the same dewatering/mixing process with the final dewatering carried out on the split samples. Care was taken to handle both samples in the same manner with mass balance of the water removed per bulk mass of simulant present in the containers taken into account and kept constant for both samples. This observation/measurement provides an indication of the sensitivity of shear strength to very small changes in the simulant handling, make-up, and water content. While not included in the average value calculated and reported in Table 3.2, the high value for KW-B is reported in Table 3.5 because the magnitude of the measurement is comparable to that observed in Schmidt and Zacher (2007) after a settler tank simulant was transported in a vehicle. 
Table 3.5. Shear-Strength Measurements

\begin{tabular}{|c|c|c|c|c|c|}
\hline \multicolumn{6}{|l|}{ KW-B (M-500) Shear-Strength Measurements } \\
\hline Conditions & $\begin{array}{c}\text { Gel Time } \\
\text { (hours) }\end{array}$ & Shear Strength $(\mathrm{Pa})$ & ave & & std \\
\hline *Mid point & 21 & 2350 & & & \\
\hline++ Added fines and mixed top, Mid point & 48 & 5715 & & & \\
\hline *Bottom & 21 & 1597 & & & \\
\hline *Mid point & 24 & 1209 & 1719 & \pm & 580 \\
\hline Mid point & 48 & 797 & & & \\
\hline *Bottom & 48 & 1174 & 986 & \pm & 266 \\
\hline *Mid point & 91 & 1543 & & & \\
\hline *Bottom & 91 & 1495 & 1519 & \pm & 34 \\
\hline \multicolumn{6}{|l|}{++ not included in average value } \\
\hline \multicolumn{6}{|l|}{ ST-A Shear-Strength Measurements } \\
\hline Conditions & $\begin{array}{c}\text { Gel Time } \\
\text { (hours) }\end{array}$ & Shear Strength $(\mathrm{Pa})$ & ave & & std \\
\hline *Mid point & 21 & 516 & & & \\
\hline *Mid point & 24 & 465 & & & \\
\hline *Bottom & 24 & 627 & 536 & \pm & 83 \\
\hline Mid point & 48 & 612 & & & \\
\hline *Mid point & 91 & 604 & & & \\
\hline *Bottom & 91 & 1214 & 909 & \pm & 431 \\
\hline
\end{tabular}

The flow-curve analyses for the settler sample and KW-B M500 sample were attempted several times using the concentric cylinder and vane sensor on the TA Rheometer and the Haake RS 600 Rheometer. Particle interaction within the sludge during analysis caused flocculation/agglomeration of the particles. It is suspected that the clustering of particles created a particle bridge in the 1-mm gap between cup and rotor, causing the sensors on both rheometers to stick. Sticking caused the instruments to exceed their maximum allowable torque, which triggers the instrument to terminate the flow-curve analysis to prevent damage to the instrument.

Flow-curve analyses were also attempted with the vane Rheometer setup. However, due to the nature of the rapidly settling simulant, consistent/reportable results were not obtained. Different geometries need to be investigated using this setup to determine if this method is suitable for these types of simulants.

One major consideration in performing a valid rheological measurement of a sample is to identify the necessary gap size between the sensor and the cup to verify that the particle size (in this case agglomeration of particles) does not affect the measurement of the flow curve. In our case, the $\sim 1-\mathrm{mm}$ gap was not sufficiently large, and as such, it was not possible to measure the flow properties of the sludge using the concentric cylinder and vane sensor. Therefore, the flow-curve analysis was performed on the TA Rheometer using a parallel plate geometry at room temperature. Sample dilution was not attempted using this setup because this technique is limited to concentrated/viscose samples. Initially, a plate distance of $1 \mathrm{~mm}$ was used, which once again resulted in particle bridging/jamming. The minimum plate gap required for this method is three times the largest particle present in the sample being analyzed. Optimally, a gap size of 10 times the largest particle is desired where practically possible. Next, a 3-mm plate gap was used to measure the flow curves and obtain viscosity plots (Figure 3.5 and Figure 3.6 and 
Appendix C), Slurry particles were seen to agglomerate at the edges of the two plates while taking measurements. A summary of down fits using the Bingham model is given in Table 3.6. Both the settler and the KW-B simulants were measured in triplicate, and all plots associated with these measurements can be found in Appendix C. The up-ramp data indicate significant yield strength. From Figure 3.5, it can be seen that the up-ramp is highly non-linear, possibly indicating structural disruption or possibly bridging effects, even in the 3-mm-gap data.

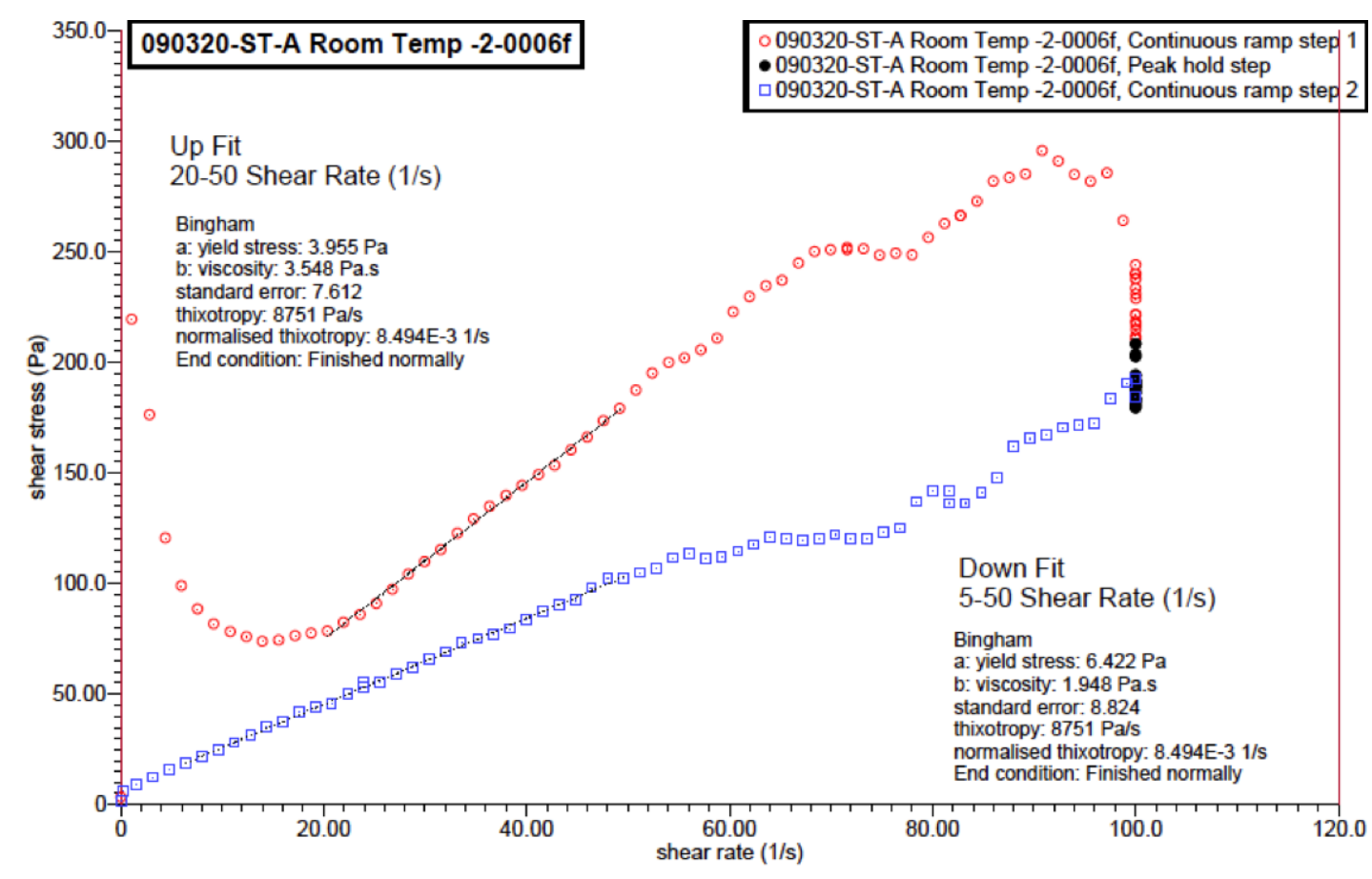

Figure 3.5. Shear Stress Versus Shear Rate of Settler Simulant

The observed hysteresis is indicative of significant structural changes to the sample upon shearing, which is typical for dense slurries. The down-ramp data obtained are most likely indicative of the well mixed, fully disrupted slurry rheology, and show a relatively linear, Bingham-type stress response. Optimization of measuring shear strength needs to be investigated for these difficult materials. 


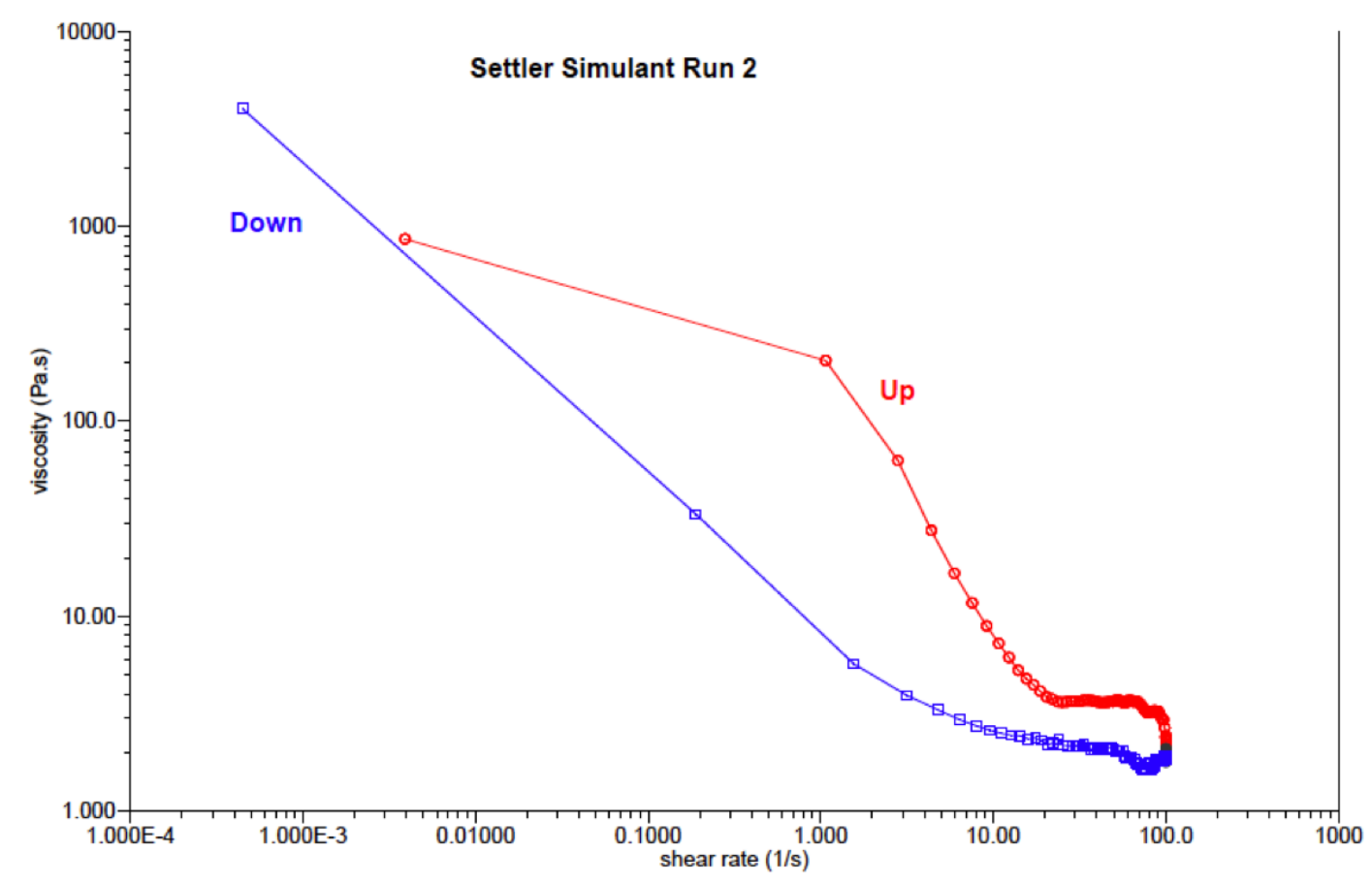

Figure 3.6. Viscosity Versus Shear Rate Obtained for the Settler Simulant shown Figure 3.5

Table 3.6. Bingham Down Fits

\begin{tabular}{ccc}
\hline & \multicolumn{2}{c}{ Down Fit } \\
\cline { 2 - 3 } Run Number & Yield stress & $\begin{array}{c}\text { Viscosity } \\
\text { Pa.s }\end{array}$ \\
\hline ST-A & & \\
\hline 1 & 6.007 & 2.35 \\
2 & 6.422 & 1.948 \\
3 & 6.692 & 2.396 \\
KW-B (M-500) & & \\
\hline 1 & 21.86 & 3.402 \\
2 & 27.39 & 2.248 \\
3 & 21.51 & 1.63 \\
\hline
\end{tabular}




\subsection{Reporting}

Experimental data have been recorded in an official PNNL Laboratory Record Book where laboratory notes were taken.

An independent review of the electronic files used for data analysis has being executed. 


\subsection{References}

RB Baker, JA Pottmeyer, JL Westcott, AJ Schmidt and TL Welsh. 2009. Quality Assurance Project Plan/Sampling and Analysis Plan for Sludge in the KW Engineered Containers. KBC-33786, Rev. 1, CH2MHill Plateau Remediation Company, Richland, Washington.

Daniel RC. 2007. PNNL Technical Procedure: Measurement of Physical and Rheological Properties of Solutions, Slurries and Sludges. RPL-Colloid-02 Rev. 1, Pacific Northwest National Laboratory, Richland, Washington.

Schmidt AJ. 2009. Spent Nuclear Fuel Project Technical Databook. Vol. 2, "Sludge," Rev. 14, HNFSD-SNF-TI-015, Fluor Hanford, Inc. Richland, Washington.

Schmidt AJ and AH Zacker. 2007. Composition and Technical Basis for K Basin Settler Slduge Simulant for Inspection, Retrieval and Pump Testing. PNNL-16619, Rev 1., Pacific Northwest National Laboratory, Richland, Washington. 
Appendix A

\section{Simulant Material Provided to Pacific Northwest National Laboratory}




\section{Appendix A: Simulant Material Provided to Pacific Northwest National Laboratory}

These simulant formulations and copies of chain-of-custody documents are included in this Appendix. The simulant compositions are documented in a memorandum. ${ }^{(a)}$

1) Sludge Treatment Project Base Simulant Recipes

2) Settler Tank Simulant, ST-A

Chain of Custody

Simulant Preparation Data Sheet

Simulant Component Source Data

Characterization Request

3) KW Container Simulant, KW-A, Complete

Chain of Custody

Simulant Preparation Data Sheet

Simulant Component Source Data

Characterization Request

4) KW Container Simulant, KW-B, P500 and M500 (size fractionated)

Chain of Custody

Simulant Preparation Data Sheet

Simulant Component Source Data

Characterization Request

(a) GT MacLean. 2008. K Basin Sludge Simulants. Letter Report from GT MacLean (Fluor Government Group) to R Lokken, August 7, 2008, Fluor Government Group, Richland, Washington. 
Fluor Government Group

Richland Office

1200 Jadwin Avenue, PO Box 1050

Richland, WA 99352-1050

509.372 .0405

509.373 .6471

\section{Memorandum}

\begin{tabular}{|c|c|c|c|c|}
\hline $\begin{array}{l}\text { To: } \\
\text { Location: }\end{array}$ & $\begin{array}{l}\text { Ryan Lokken } \\
4710 / 309 / 400\end{array}$ & & $\begin{array}{l}\text { Date: } \\
\text { Reference: }\end{array}$ & $08 / 07 / 2008$ \\
\hline From: & Graham MacLean & & & \\
\hline Location: & $1200 \mathrm{Jadwin} / 247$ & & Client: & FH \\
\hline Phone: & $372-0405$ & & Subject: & K-Basin Sludge Simulants \\
\hline FAX: & $373-6471$ & & & \\
\hline c: & Andy Schmidt & P8-60 & & \\
\hline
\end{tabular}

Primary or base recipes (formulations) have been selected for mixtures that represent the combined sludges in three groupings:

1. KE Basin origin sludges that currently reside in KW Containers 240,250 , and 260

2. KW Basin sludges that currently and will reside in KW Containers 210 and 220

3. KW Settler-tube sludge that will reside in $\mathrm{KW}$ container 230

The KE Basin and KW settler-tube sludge recipes have been selected from those listed in Table 2 of A21C-STP-TI-0001, Rev. 0, "K Basin Sludge Simulant Recipe Book." The identifications are shown in parentheses in the tables below. The KW Basin sludge recipe, also shown below, was developed after the initial Recipe Book was issued. Data tables and particle size plots are include to show an example composition that meets the specifications.

KE Basin Container Sludge Simulant (\#11 - modified rheology simulant based on 93 vol.\% KE floor sludge and 7 vol.\% KE canister sludge)

\begin{tabular}{c|c|c|}
\hline Material & Amount, wt. $\%$ & Particle Size Specification \\
\hline $\mathrm{FeOOH}$ or $\mathrm{Fe}(\mathrm{OH})_{3}$ & 32.1 & $\mathrm{~d}_{10}=6 \mu \mathrm{m}, \mathrm{d}_{50}=13 \mu \mathrm{m}, \mathrm{d}_{90}=19 \mu \mathrm{m}$ \\
\hline Sand & 24.1 & $\mathrm{~d}_{10}=.17 \mathrm{~mm}, \mathrm{~d}_{50}=.30 \mathrm{~mm}, \mathrm{~d}_{90}=.56 \mathrm{~mm}$ \\
\hline Aggregate & 14.3 & $\mathrm{~d}_{10}=2.0 \mathrm{~mm}, \mathrm{~d}_{50}=2.8 \mathrm{~mm}, \mathrm{~d}_{90}=4.0 \mathrm{~mm}$ \\
\hline Al(OH) $)_{3}$ & 12.1 & $\mathrm{~d}_{10}=2 \mu \mathrm{m}, \mathrm{d}_{50}=13 \mu \mathrm{m}, \mathrm{d}_{90}=47 \mu \mathrm{m}$ \\
\hline $\mathrm{CeO}_{2}$ or equivalent & 12.1 & $\mathrm{~d}_{10}=.5 \mu \mathrm{m}, \mathrm{d}_{50}=4 \mu \mathrm{m}, \mathrm{d}_{90}=19 \mu \mathrm{m}$ \\
\hline Steel Grit or equivalent & 4.1 & $\mathrm{~d}_{10}=1.9 \mathrm{~mm}, \mathrm{~d}_{50}=2.3 \mu \mathrm{m}, \mathrm{d}_{90}=2.7 \mu \mathrm{m}$ \\
\hline Dense metal or alloy & 1.2 & $\mathrm{~d}_{10}=.30 \mathrm{~mm}, \mathrm{~d}_{50}=.60 \mathrm{~mm}, \mathrm{~d}_{90}=1.41 \mathrm{~mm}$ \\
\hline Total & 100.0 & $\mathrm{~d}_{10}=4 \mu \mathrm{m}, \mathrm{d}_{50}=20 \mu \mathrm{m}, \mathrm{d}_{90}=2.6 \mathrm{~mm}$ \\
\hline
\end{tabular}




\begin{tabular}{|c|c|c|c|c|c|c|c|c|c|}
\hline 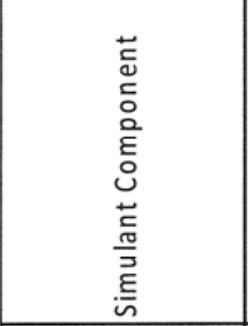 & 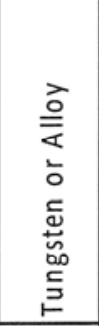 & 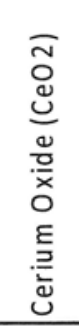 & 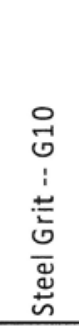 & 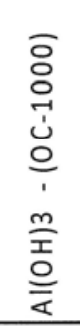 & 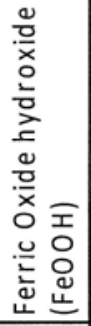 & 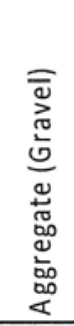 & 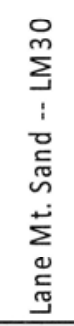 & 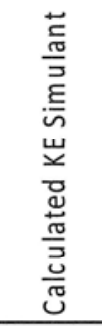 & 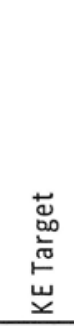 \\
\hline Wt. \%, dry & 1.2 & 12.1 & 4.1 & 12.1 & 32.1 & 14.3 & 24.1 & 100.0 & \\
\hline $\begin{array}{c}\text { Particle Density, } \\
\mathrm{g} / \mathrm{cm}^{3} \\
\end{array}$ & 16.9 & 7.13 & 7.86 & 2.42 & 2.85 & 2.6 & 2.6 & 3.00 & 2.74 \\
\hline $\begin{array}{c}\text { Particle Size, } \\
\text { microns }\end{array}$ & \multicolumn{9}{|c|}{ Cumulative Percent Finer Than } \\
\hline 6350 & 100 & 100 & 100 & 100 & 100 & 100 & 100 & 100 & 100 \\
\hline 4000 & 95.24 & 100 & 100 & 100 & 100 & 90 & 100 & 99 & 99 \\
\hline 1410 & 90 & 100 & 0 & 100 & 100 & 6 & 100 & 82 & 86 \\
\hline 500 & 36.67 & 100 & 0 & 100 & 100 & 0 & 84 & 77 & 79 \\
\hline 250 & 0 & 100 & 0 & 100 & 100 & 0 & 38 & 65 & 67 \\
\hline 100 & 0 & 100 & 0 & 98 & 100 & 0 & 2 & 57 & 65 \\
\hline 50 & 0 & 99 & 0 & 93 & 99 & 0 & 0 & 55 & 58 \\
\hline 40 & 0 & 97 & 0 & 80 & 92 & 0 & 0 & 51 & 56 \\
\hline 30 & 0 & 94 & 0 & 73 & 94 & 0 & 0 & 51 & 50 \\
\hline 20 & 0 & 91 & 0 & 66 & 97 & 0 & 0 & 50 & 43 \\
\hline 10 & 0 & 73 & 0 & 42 & 32 & 0 & 0 & 24 & 28 \\
\hline 5 & 0 & 57 & 0 & 24 & 6 & 0 & 0 & 12 & 17 \\
\hline 1 & 0 & 37 & 0 & 4 & 0 & 0 & 0 & 5 & 3 \\
\hline
\end{tabular}

\begin{tabular}{|r|r|r|r|r|r|r|r||r|r|}
\hline $\mathrm{d} 90$ & 1410 & 19 & 2706 & 47 & 19 & 4000 & 562 & 2560 & 2207 \\
\hline $\mathrm{d} 50$ & 600 & 4 & 2329 & 13 & 13 & 2800 & 295 & 20 & 31 \\
\hline $\mathrm{d} 10$ & 300 & 0 & 1875 & 2 & 6 & 2000 & 166 & 4 & 3 \\
\hline
\end{tabular}

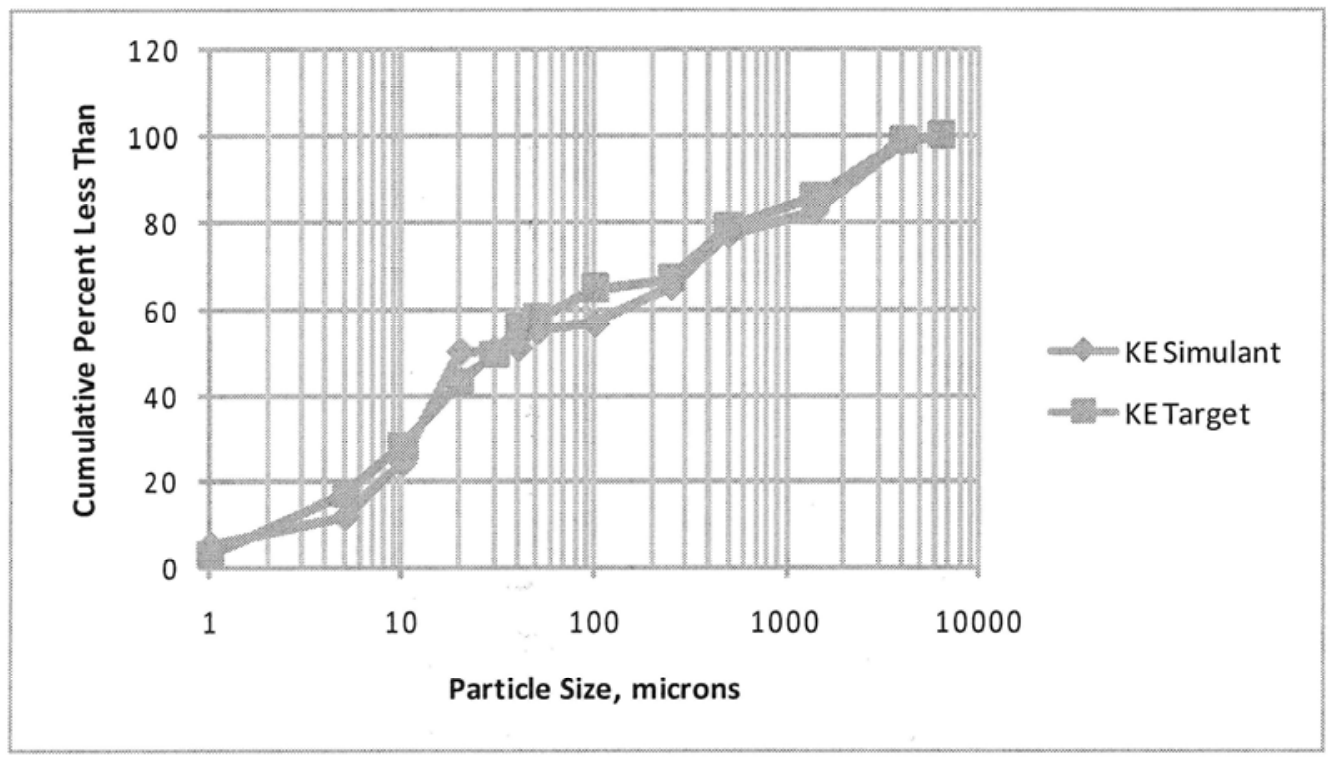


KW Basin Container Sludge Simulant (based on mixture of all KW floor sludge and pit sludge sources)

\begin{tabular}{|c|c|c|}
\hline Material & Amount, wt. \% & Particle Size Specification \\
\hline $\mathrm{CeO}_{2}$ or equivalent & 30.9 & $\mathrm{~d}_{10}=<1 \mu \mathrm{m}, \mathrm{d}_{50}=4 \mu \mathrm{m}, \mathrm{d}_{90}=19 \mu \mathrm{m}$ \\
\hline $\mathrm{FeOOH}$ or $\mathrm{Fe}(\mathrm{OH})_{3}$ & 21.9 & $\mathrm{~d}_{10}=6 \mu \mathrm{m}, \mathrm{d}_{50}=13 \mu \mathrm{m}, \mathrm{d}_{90}=19 \mu \mathrm{m}$ \\
\hline Sand & 14.7 & $\mathrm{~d}_{10}=.17 \mathrm{~mm}, \mathrm{~d}_{50}=.30 \mathrm{~mm}, \mathrm{~d}_{90}=.56 \mathrm{~mm}$ \\
\hline Aggregate & 16.9 & $\mathrm{~d}_{10}=1.3 \mathrm{~mm}, \mathrm{~d}_{50}=2.2 \mathrm{~mm}, \mathrm{~d}_{90}=3.7 \mathrm{~mm}$ \\
\hline Al(OH) $)_{3}$ & 7.8 & $\mathrm{~d}_{10}=2 \mu \mathrm{m}, \mathrm{d}_{50}=13 \mu \mathrm{m}, \mathrm{d}_{90}=47 \mu \mathrm{m}$ \\
\hline Steel Grit or equivalent & 4.2 & $\mathrm{~d}_{10}=.18 \mathrm{~mm}, \mathrm{~d}_{50}=.39 \mathrm{~mm}, \mathrm{~d}_{90}=.50 \mathrm{~mm}$ \\
\hline Dense metal or alloy & 3.6 & $\mathrm{~d}_{10}=.41 \mathrm{~mm}, \mathrm{~d}_{50}=1.8 \mathrm{~mm}, \mathrm{~d}_{90}=4.4 \mathrm{~mm}$ \\
\hline Total & 100.0 & $\mathrm{~d}_{10}=1 \mu \mathrm{m}, \mathrm{d}_{50}=17 \mu \mathrm{m}, \mathrm{d}_{90}=2.2 \mathrm{~mm}$ \\
\hline
\end{tabular}

Settler Sludge Simulant (\#1 - retrieval simulant)

\begin{tabular}{|c|c|c|}
\hline Material & Amount, wt. \% & Particle Size Specification \\
\hline $\mathrm{CeO}_{2}$ or equivalent & 68 & $\mathrm{~d}_{10}=.3 \mu \mathrm{m}, \mathrm{d}_{50}=4 \mu \mathrm{m}, \mathrm{d}_{90}=19 \mu \mathrm{m}$ \\
\hline Steel Grit or equivalent & 14 & $\mathrm{~d}_{10}=.10 \mathrm{~mm}, \mathrm{~d}_{50}=.34 \mathrm{~mm}, \mathrm{~d}_{90}=.53 \mathrm{~mm}$ \\
\hline Fly Ash & 11 & $\mathrm{~d}_{10}=1.4 \mu \mathrm{m}, \mathrm{d}_{50}=12 \mu \mathrm{m}, \mathrm{d}_{90}=96 \mu \mathrm{m}$ \\
\hline Dense metal or alloy & 6 & $\mathrm{~d}_{10}=.28 \mathrm{~mm}, \mathrm{~d}_{50}=.40 \mathrm{~mm}, \mathrm{~d}_{90}=.53 \mathrm{~mm}$ \\
\hline $\mathrm{Fe}(\mathrm{OH})_{3}$ & 1 & $\mathrm{~d}_{10}=.2 \mu \mathrm{m}, \mathrm{d}_{50}=.6 \mu \mathrm{m}, \mathrm{d}_{90}=1.0 \mu \mathrm{m}$ \\
\hline Total & 100.0 & $\mathrm{~d}_{10}=.10 \mathrm{~mm}, \mathrm{~d}_{50}=.34 \mathrm{~mm}, \mathrm{~d}_{90}=1.0 \mathrm{~mm}$ \\
\hline
\end{tabular}




\begin{tabular}{|c|c|c|c|c|c|c|c|c|c|}
\hline 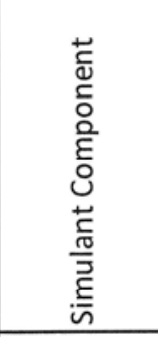 & 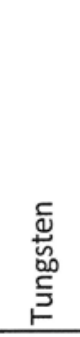 & 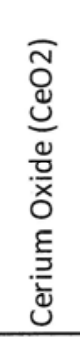 & 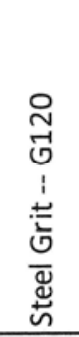 & 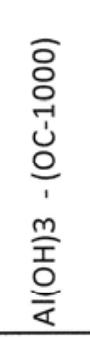 & 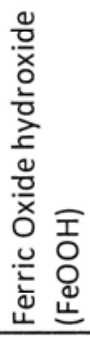 & 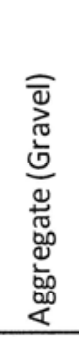 & 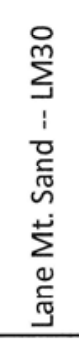 & 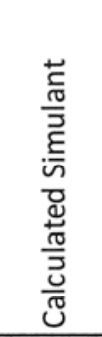 & 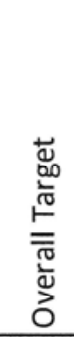 \\
\hline Wt. \%, dry & 3.6 & 30.9 & 4.2 & 7.8 & 21.9 & 16.9 & 14.7 & 100.0 & \\
\hline $\begin{array}{c}\text { Particle } \\
\text { Density, } \\
\mathrm{g} / \mathrm{cm}^{3}\end{array}$ & 16.9 & 7.13 & 7.86 & 2.42 & 2.85 & 2.6 & 2.6 & 3.55 & 3.29 \\
\hline & \multicolumn{9}{|c|}{ Particle Size Distribution, Cumulative Percent Less Than } \\
\hline 6350 & 100 & 100 & 100 & 100 & 100 & 100 & 100 & 100 & 100 \\
\hline 4000 & 88 & 100 & 100 & 100 & 100 & 98 & 100 & 99 & 99 \\
\hline 1410 & 44 & 100 & 100 & 100 & 100 & 31 & 100 & 86 & 86 \\
\hline 500 & 15 & 100 & 90 & 100 & 100 & 0 & 84 & 77 & 79 \\
\hline 250 & 0 & 100 & 16 & 100 & 100 & 0 & 38 & 67 & 69 \\
\hline 100 & 0 & 100 & 0 & 98 & 100 & 0 & 2 & 61 & 67 \\
\hline 50 & 0 & 99 & 0 & 93 & 99 & 0 & 0 & 60 & 60 \\
\hline 40 & 0 & 97 & 0 & 80 & 92 & 0 & 0 & 56 & 59 \\
\hline 20 & 0 & 91 & 0 & 66 & 97 & 0 & 0 & 55 & 45 \\
\hline 10 & 0 & 73 & 0 & 42 & 32 & 0 & 0 & 33 & 31 \\
\hline 5 & 0 & 57 & 0 & 24 & 6 & 0 & 0 & 21 & 19 \\
\hline 1 & 0 & 37 & 0 & 4 & 0 & 0 & 0 & 12 & 6 \\
\hline
\end{tabular}

\begin{tabular}{|r|r|r|r|r|r|r|r|r|r|}
\hline $\mathrm{d} 90$ & 4424 & 19 & 500 & 47 & 19 & 3700 & 562 & 2176 & 2207 \\
\hline $\mathrm{d} 50$ & 1780 & 4 & 386 & 13 & 13 & 2186 & 295 & 18 & 27 \\
\hline $\mathrm{d} 10$ & 409 & 0 & 180 & 2 & 6 & 1255 & 166 & 1 & 2 \\
\hline
\end{tabular}

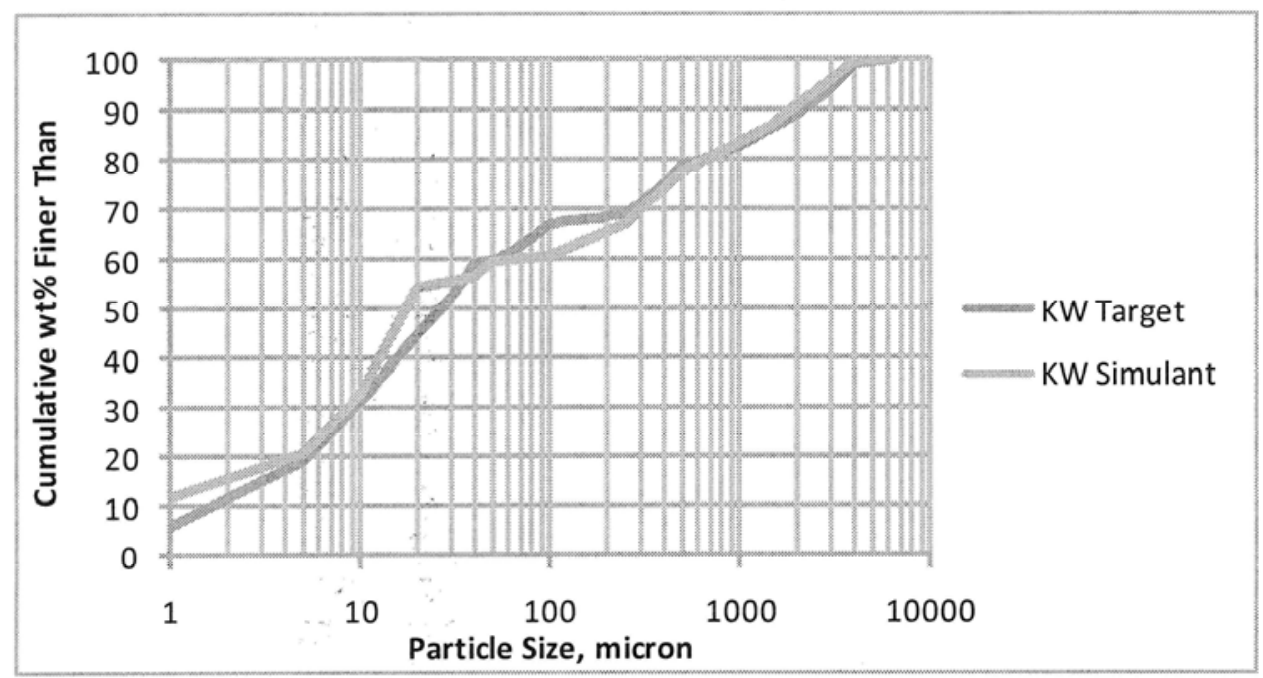




\begin{tabular}{|c|c|c|c|c|c|c|}
\hline 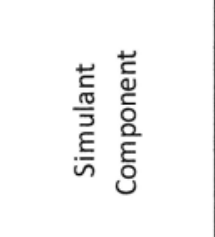 & 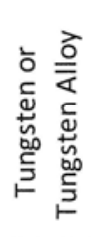 & 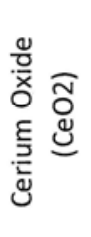 & $\begin{array}{l}\frac{c}{n} \\
\ll \\
\frac{\pi}{u} \\
u \\
u \\
\tilde{n} \\
\frac{\pi}{U}\end{array}$ & 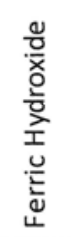 & 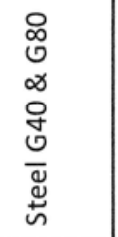 & $\begin{array}{l}\stackrel{+}{c} \\
\frac{\pi}{J} \\
\frac{E}{n}\end{array}$ \\
\hline Wt. \%, dry & 6 & 68 & 11 & 1 & 14 & 100.00 \\
\hline $\begin{array}{c}\text { Particle } \\
\text { Density, } \mathrm{g} / \mathrm{cm}^{3}\end{array}$ & 16.9 & 7.13 & 2.35 & 2.85 & 7.86 & 5.99 \\
\hline $\begin{array}{c}\text { Particle Size, } \\
\text { microns }\end{array}$ & \multicolumn{6}{|c|}{ Cumulative Percent Finer Than } \\
\hline 600 & 100 & 100 & 100 & 100 & 100 & 100 \\
\hline 500 & 85 & 100 & 100 & 100 & 85 & 97 \\
\hline 250 & 0 & 100 & 100 & 100 & 29 & 84 \\
\hline 100 & 0 & 100 & 97 & 100 & 0 & 80 \\
\hline 40 & 0 & 97 & 81 & 100 & 0 & 76 \\
\hline 20 & 0 & 91 & 65 & 100 & 0 & 70 \\
\hline 10 & 0 & 73 & 46 & 100 & 0 & 56 \\
\hline 5 & 0 & 57 & 30 & 100 & 0 & 43 \\
\hline 1 & 0 & 37 & 8 & 93 & 0 & 27 \\
\hline 0.1 & 0 & 0. & 0 & 0 & 0 & 0 \\
\hline
\end{tabular}

\begin{tabular}{|c|c|c|c|c|c|c|}
\hline $\mathrm{d} 90$ & 533 & 19 & 96 & 0.97 & 533 & \\
\hline $\mathrm{d} 50$ & 397 & 4 & 12 & 0.58 & 344 & \\
\hline $\mathrm{d} 10$ & 279 & 0.34 & 1.4 & 0.20 & 101 & \\
\hline
\end{tabular}

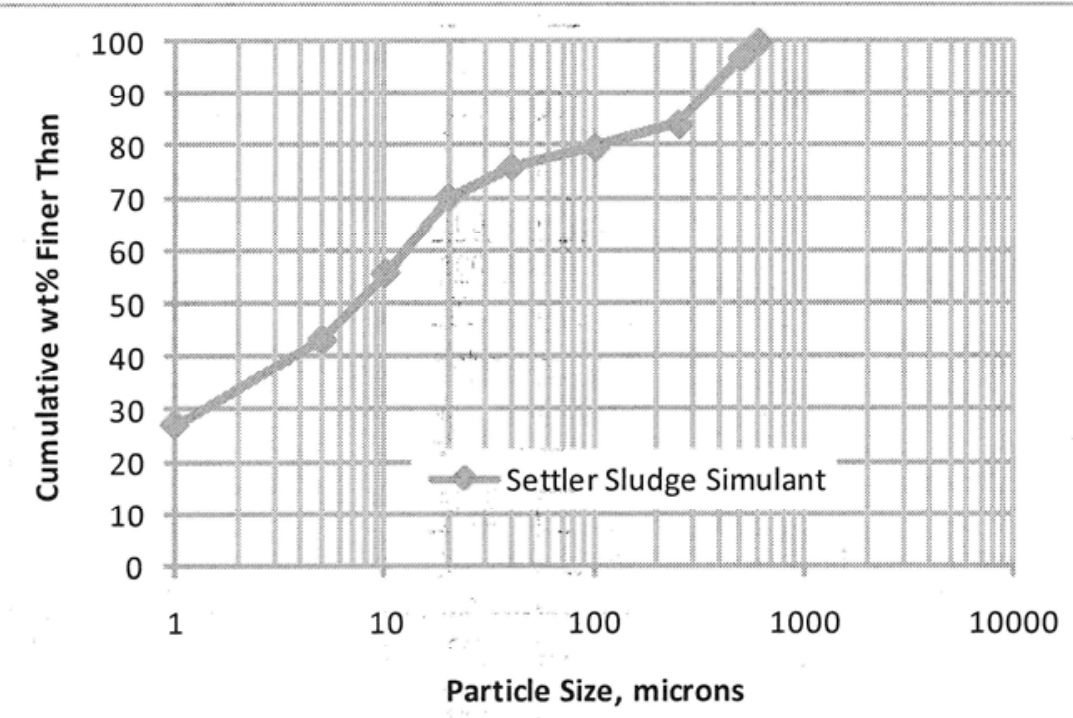


Sand represents quartz, zeolite, aluminosilicates, and other materials of similar density and particle size in the sludge. Preferably the sand should be actual Hanford blow sand obtained from drifts on site, but similar commercial sands can be used. Aggregate represents larger materials such as small rocks, concrete pieces, large corrosion products, etc. The aluminum hydroxide and ferric oxide-hydroxides represent the same compounds in the sludge that resulted from corrosion of the steel racks, aluminum cladding, etc. The dense metal is a substitute for uranium metal; tungsten metal is preferred, but other high-density (> s.g. $=14$ ) metals or alloys can be used, based on the specific test objectives.

Cerium oxide is a substitute for either all uranium oxides and hydroxides, or for just the less dense hydrated species $\left(\mathrm{UO}_{3} \cdot \mathrm{xH}_{2} \mathrm{O}\right)$. The steel grit is a substitute for $\mathrm{UO}_{2}$ and $\mathrm{U}_{4} \mathrm{O}_{9}$. $\mathrm{Bi}_{2} \mathrm{O}_{3}$, bismuth metal, or other materials having a higher specific gravity than steel and available in larger particle sizes than $\mathrm{CeO}_{2}$ may be substituted to represent $\mathrm{UO}_{2}$ and $\mathrm{U}_{4} \mathrm{O}_{9}$. None of these other materials are included in the recipes above because $\mathrm{UO}_{2}$ is not a limiting species - the uranium in actual sludge is more dense and larger in particle size than the oxides, and sand is equally or more abrasive than $\mathrm{UO}_{2}$.

The particles size specifications are the desired, but due to the large range and uncertainty in the actual sludge properties and variability in commercial products, variation in the specifications of up to about $50 \%$ are acceptable for individual ingredients, and about $20 \%$ for the overall particle sizes. The recipes above do not include ion exchange beads, but these can be added if important for certain tests. Other variations may be appropriate as determined on a case-by-case basis.

A words of caution: When a simulated waste is made with the above recipe, the settled sludge density is often considerably higher that measured in actual sludge - it compacts substantially more. This is probably because the $\mathrm{FeOOH}$ and $\mathrm{CeO}_{2}$ (which are dry powders) do not hydrate or attract and carry around water molecules like the wet iron oxide-hydroxides and $\mathrm{UO}_{3} \cdot \mathrm{xH}_{2} \mathrm{O}$ compounds do in the real sludge, making it less compressible.

\section{Concurrence:}

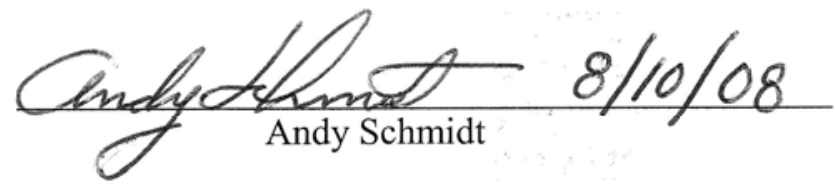




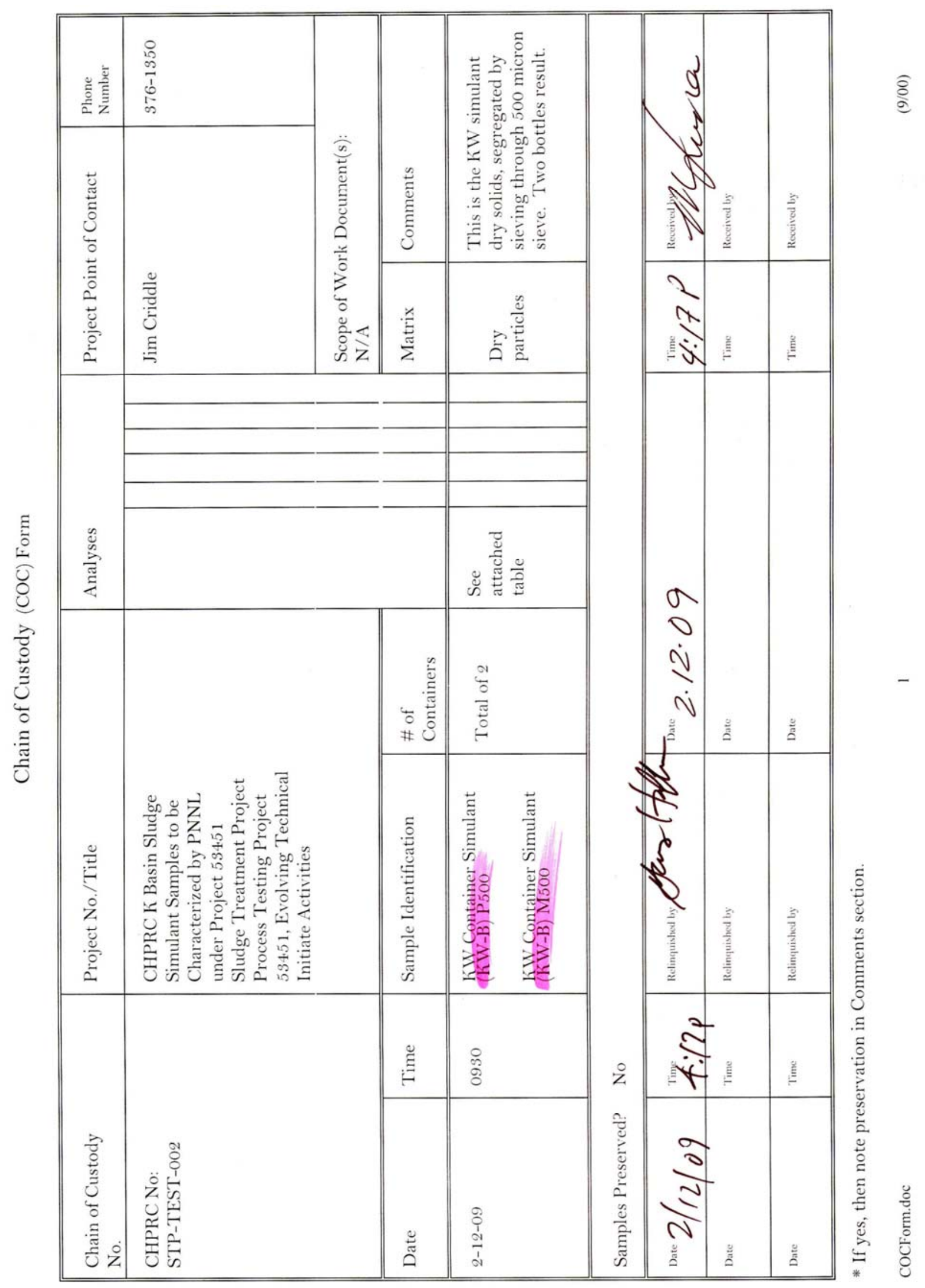


Characterization Approach for Simulant Confirmation

Attachment to CoC-1

\begin{tabular}{|c|c|c|}
\hline Property/Parameter & $\begin{array}{l}\text { Measurement/Calculation } \\
\text { Approach }\end{array}$ & Frequency \\
\hline Settled Density & $\begin{array}{l}\text { Prep simulant with excess water, allow } \\
\text { sludge to settle for } 24 \mathrm{hr} \text {, measure volume } \\
\text { and mass. }\end{array}$ & Routine $^{(a)}$ \\
\hline $\begin{array}{l}\text { Wt \% Solids } \\
\text { (in settled sludge) }\end{array}$ & $\begin{array}{l}\text { Dry aliquot (known mass and volume) of } \\
\text { as-settled sludge at } 105^{\circ} \mathrm{C} \text {, measure mass, } \\
\text { and record dry bulk volume. }\end{array}$ & Routine $^{(a)}$ \\
\hline $\begin{array}{l}\text { Volume Fraction Water } \\
\text { (in settled sludge) }\end{array}$ & $\begin{array}{l}\text { Calculated from settled density and } w t \% \\
\text { solids. Assumption: all mass loss during } \\
\text { drying at } 105^{\circ} \mathrm{C} \text { is from loss of water }\end{array}$ & Routine $^{(a)}$ \\
\hline $\begin{array}{l}\text { Volume Fraction Solids } \\
\text { (in settled sludge) }\end{array}$ & Calculated from Volume Fraction Water & Routine $^{(a)}$ \\
\hline Settling Rate & Graduated cylinder and stop watch & Routine $^{(a)}$ \\
\hline \multirow{3}{*}{ Average Particle Density } & $\begin{array}{l}\text { Calculated from } \mathrm{Wt} \% \text { solids and } \mathrm{Vol} \\
\text { fraction solids }\end{array}$ & Routine $^{(a)}$ \\
\hline & $\begin{array}{l}\text { Calculated from vendor/handbook data } \\
\text { on simulant components and simulant } \\
\text { make up }\end{array}$ & Routine $^{(a)}$ \\
\hline & $\begin{array}{l}\text { Representative dry sample, density via } \\
\text { pycnometry }\end{array}$ & $\begin{array}{l}\text { As needed }{ }^{(b)} \text {, can be used to } \\
\text { confirm individual } \\
\text { components }\end{array}$ \\
\hline \multirow{3}{*}{ Particle Size Distribution } & $\begin{array}{l}\text { Calculated from vendor data on } \\
\text { components and simulant make up }\end{array}$ & Routine $^{(a)}$ \\
\hline & $<500 \mu \mathrm{m}$ - Particle size analyzer & Routine $^{(a)}$ \\
\hline & $\begin{array}{l}\text { Sieve full sample using the following } \\
\text { Sieves: } 2000 \mu \mathrm{m} \text { and } 500 \mu \mathrm{m}-\text { dry mass } \\
\text { of resulting three fraction }\end{array}$ & Routine $^{(a)}$ \\
\hline $\begin{array}{l}\text { Viscosity vs Shear Rate } \\
\text { Shear Stress vs. Shear Rate } \\
\text { (Rheograms) }\end{array}$ & $\begin{array}{l}<500 \mu \mathrm{m} \text { fraction: } \\
\text { Concentrations: as settled, } 75 \%, 50 \% \text { and } \\
25 \% \text { volume ratio of as settled + water.. } \\
\text { Rheology of Each concentration will be } \\
\text { measured at } 55^{\circ} \mathrm{F} \text { and } 72^{\circ} \mathrm{F}\end{array}$ & Routine $^{(\mathrm{a})(\mathrm{c})}$ \\
\hline Shear strength & $\begin{array}{l}<500 \mu \mathrm{m} \text { fraction: } \\
\text { Settled sludge ( } 48 \text { to } 72 \text { hour gel time, } \\
\text { vane rheometer }\end{array}$ & Routine $^{(a)}$ \\
\hline \multicolumn{3}{|c|}{$\begin{array}{l}\text { (a) Routine - Recommend base characterization for all simulants. Significant data from actual sludge } \\
\text { exists for comparison. } \\
\text { (b) As needed - based on testing objectives for specific simulant, (note part of scope). } \\
\text { (c) There is a limited set of rheograms from actual sludge to compare to rheograms from simulants }\end{array}$} \\
\hline
\end{tabular}




\section{KW Simulant Sample Batch - Segregated (KW-B)}

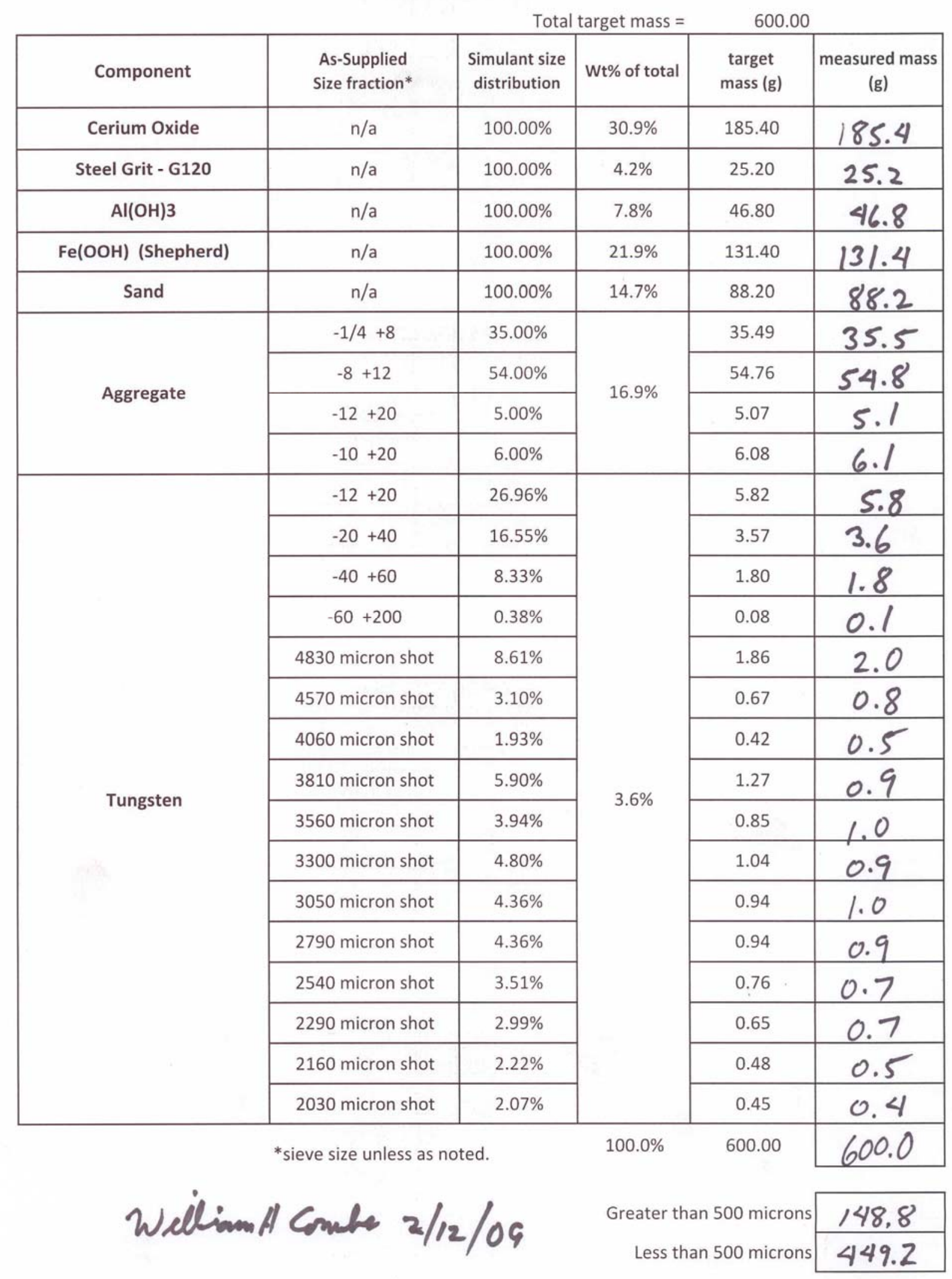




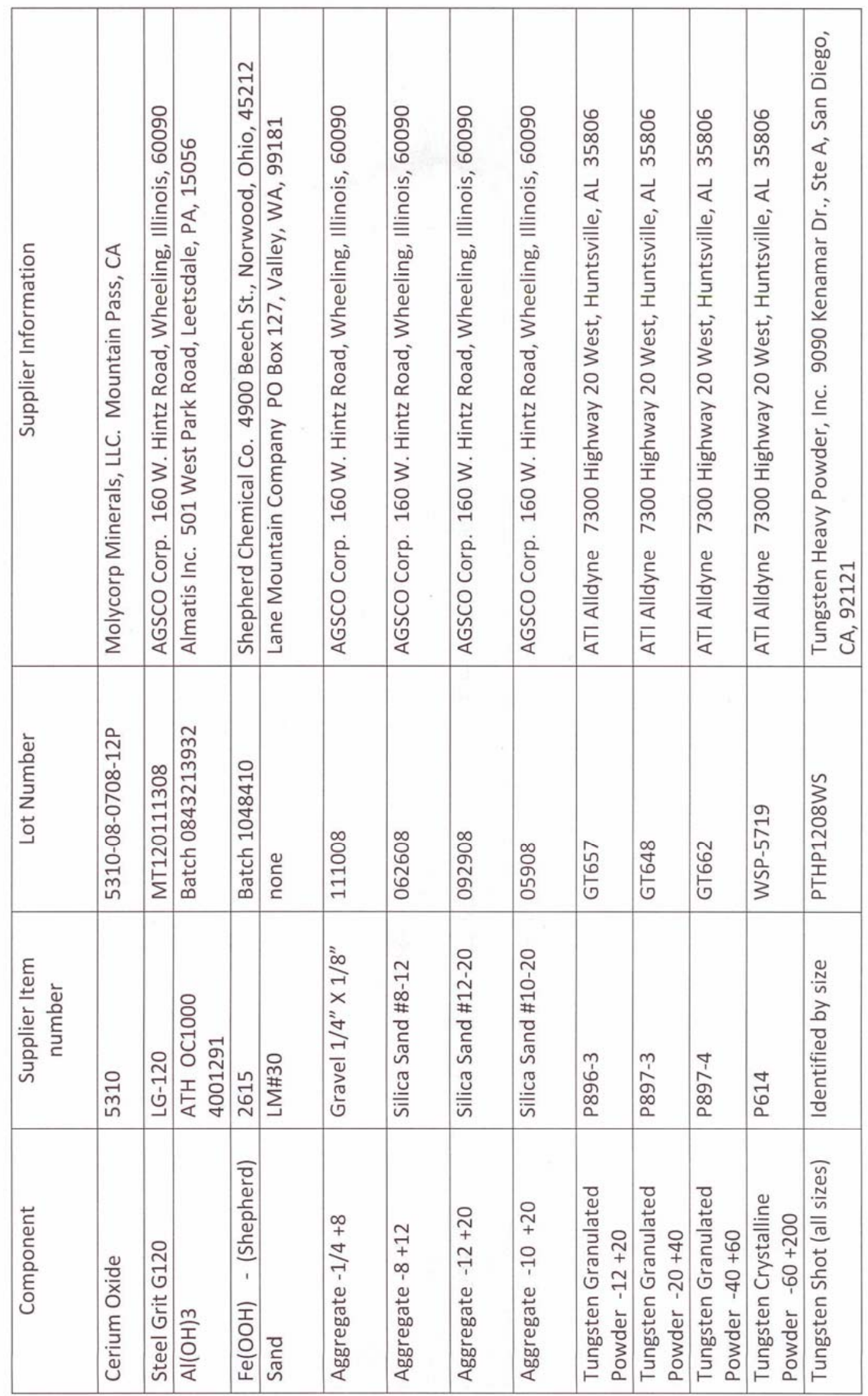




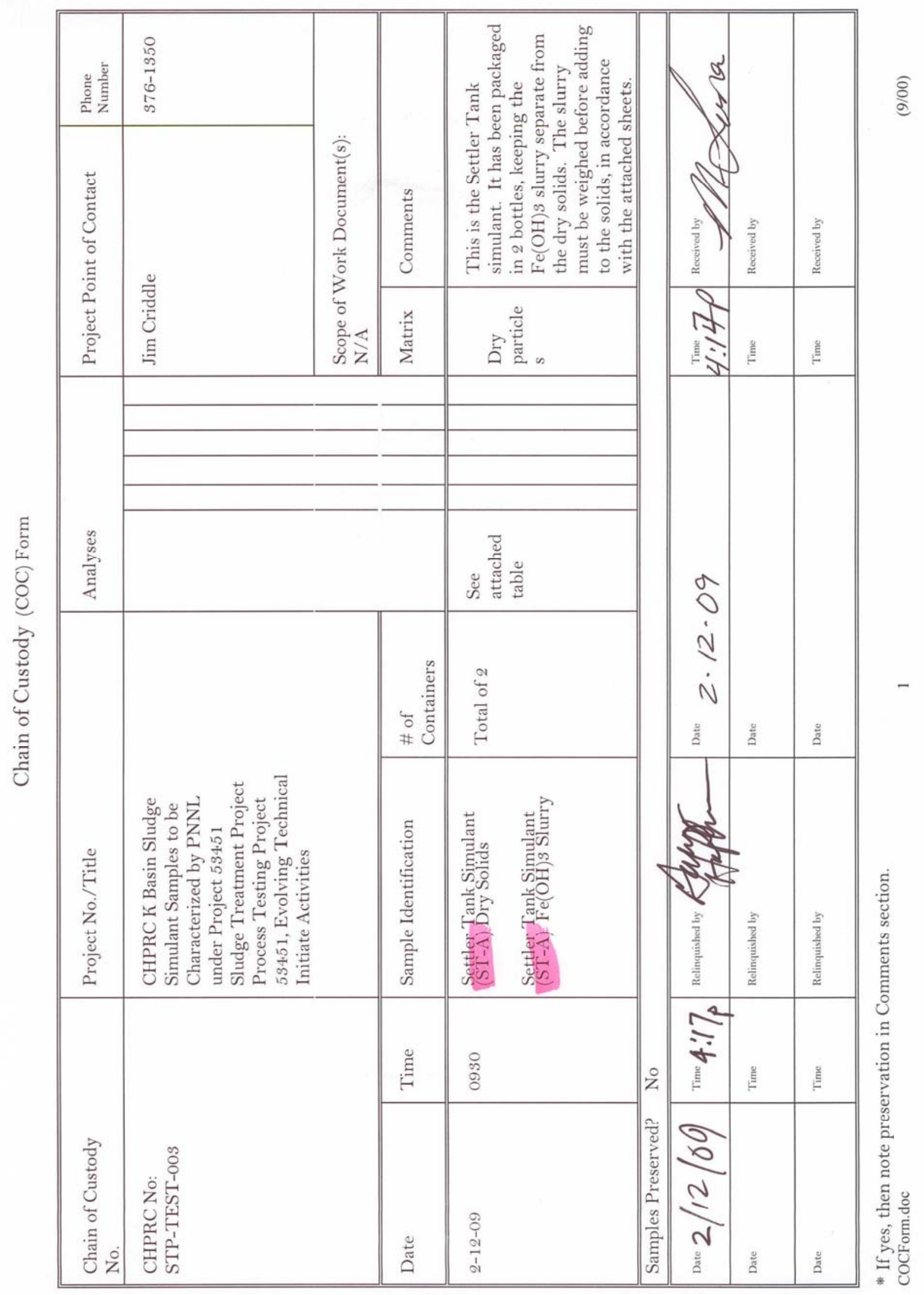

A. 12 


\section{Characterization Approach for Simulant Confirmation}

Attachment to CoC-1

\begin{tabular}{|c|c|c|}
\hline Property/Parameter & $\begin{array}{c}\text { Measurement/Calculation } \\
\text { Approach }\end{array}$ & Frequency \\
\hline Settled Density & $\begin{array}{l}\text { Prep simulant with excess water, allow } \\
\text { sludge to settle for } 24 \mathrm{hr} \text {, measure volume } \\
\text { and mass. }\end{array}$ & Routine $^{(a)}$ \\
\hline $\begin{array}{l}\text { Wt \% Solids } \\
\text { (in settled sludge) }\end{array}$ & $\begin{array}{l}\text { Dry aliquot (known mass and volume) of } \\
\text { as-settled sludge at } 105^{\circ} \mathrm{C} \text {, measure mass, } \\
\text { and record dry bulk volume. }\end{array}$ & Routine $^{(a)}$ \\
\hline $\begin{array}{l}\text { Volume Fraction Water } \\
\text { (in settled sludge) }\end{array}$ & $\begin{array}{l}\text { Calculated from settled density and } w t \% \\
\text { solids. Assumption: all mass loss during } \\
\text { drying at } 105^{\circ} \mathrm{C} \text { is from loss of water }\end{array}$ & Routine $^{(a)}$ \\
\hline $\begin{array}{l}\text { Volume Fraction Solids } \\
\text { (in settled sludge) }\end{array}$ & Calculated from Volume Fraction Water & Routine $^{(a)}$ \\
\hline Settling Rate & Graduated cylinder and stop watch & Routine $^{(a)}$ \\
\hline \multirow{3}{*}{ Average Particle Density } & $\begin{array}{l}\text { Calculated from } \mathrm{Wt} \% \text { solids and } \mathrm{Vol} \\
\text { fraction solids }\end{array}$ & Routine $^{(a)}$ \\
\hline & $\begin{array}{c}\text { Calculated from vendor/handbook data } \\
\text { on simulant components and simulant } \\
\text { make up }\end{array}$ & Routine $^{(a)}$ \\
\hline & $\begin{array}{l}\text { Representative dry sample, density via } \\
\text { pycnometry }\end{array}$ & $\begin{array}{l}\text { As needed }{ }^{(b)} \text {, can be used to } \\
\text { confirm individual } \\
\text { components }\end{array}$ \\
\hline \multirow{3}{*}{ Particle Size Distribution } & $\begin{array}{l}\text { Calculated from vendor data on } \\
\text { components and simulant make up }\end{array}$ & Routine $^{(a)}$ \\
\hline & $<500 \mu \mathrm{m}$ - Particle size analyzer & Routine $^{(a)}$ \\
\hline & $\begin{array}{l}\text { Sieve full sample using the following } \\
\text { Sieves: } 2000 \mu \mathrm{m} \text { and } 500 \mu \mathrm{m}-\text { dry mass } \\
\text { of resulting three fraction }\end{array}$ & Routine $^{(a)}$ \\
\hline $\begin{array}{l}\text { Viscosity vs Shear Rate } \\
\text { Shear Stress vs. Shear Rate } \\
\text { (Rheograms) }\end{array}$ & $\begin{array}{l}<500 \mu \mathrm{m} \text { fraction: } \\
\text { Concentrations: as settled, } 75 \%, 50 \% \text { and } \\
25 \% \text { volume ratio of as settled }+ \text { water.. } \\
\text { Rheology of Each concentration will be } \\
\text { measured at } 55^{\circ} \mathrm{F} \text { and } 72^{\circ} \mathrm{F}\end{array}$ & Routine $^{(\mathrm{a})(\mathrm{c})}$ \\
\hline Shear strength & $\begin{array}{l}<500 \mu \mathrm{m} \text { fraction: } \\
\text { Settled sludge ( } 48 \text { to } 72 \text { hour gel time, } \\
\text { vane rheometer }\end{array}$ & Routine $^{(a)}$ \\
\hline \multicolumn{3}{|c|}{$\begin{array}{l}\text { (a) Routine-Recommend base characterization for all simulants. Significant data from actual sludge } \\
\text { exists for comparison. } \\
\text { (b) As needed - based on testing objectives for specific simulant, (note part of scope). } \\
\text { (c) There is a limited set of rheograms from actual sludge to compare to rheograms from simulants }\end{array}$} \\
\hline
\end{tabular}


Settler Simulant Sample Batch (ST-A)

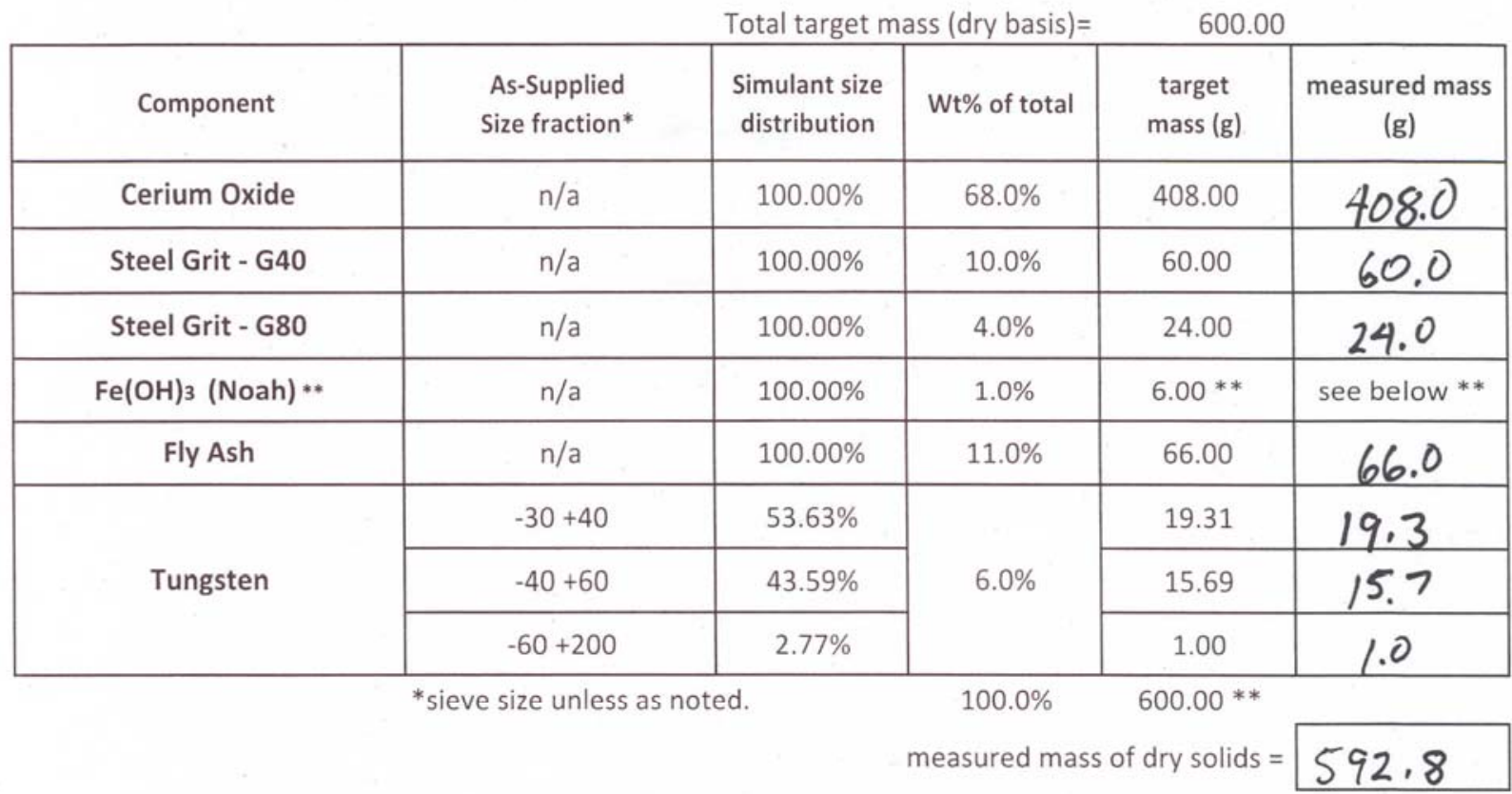

** This material comes in a slurry and will be kept separate from the dry solids.

It is advertiseds as $13 \%$ wt solids. To achieve the required 6 grams of solids, add ( $6.0 / .13=\underline{46.2}$ grams) to the provided Dry solids to make the sample batch. NOTE... the supplied container will contain extra material to assist you in obtaining the correct amount... the container will have 70 grams. Discard unused portion.

$70.0 \mathrm{gm}$

Willinath Combe $3 / 12 / 09$ 


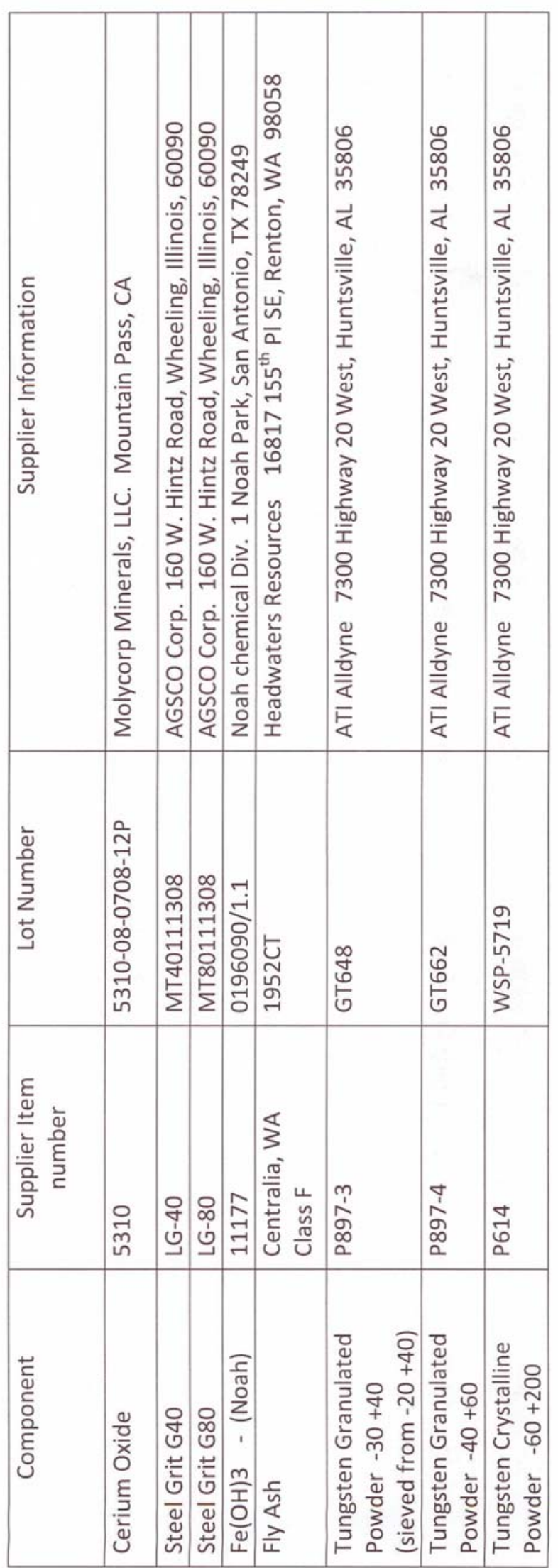

A. 15 


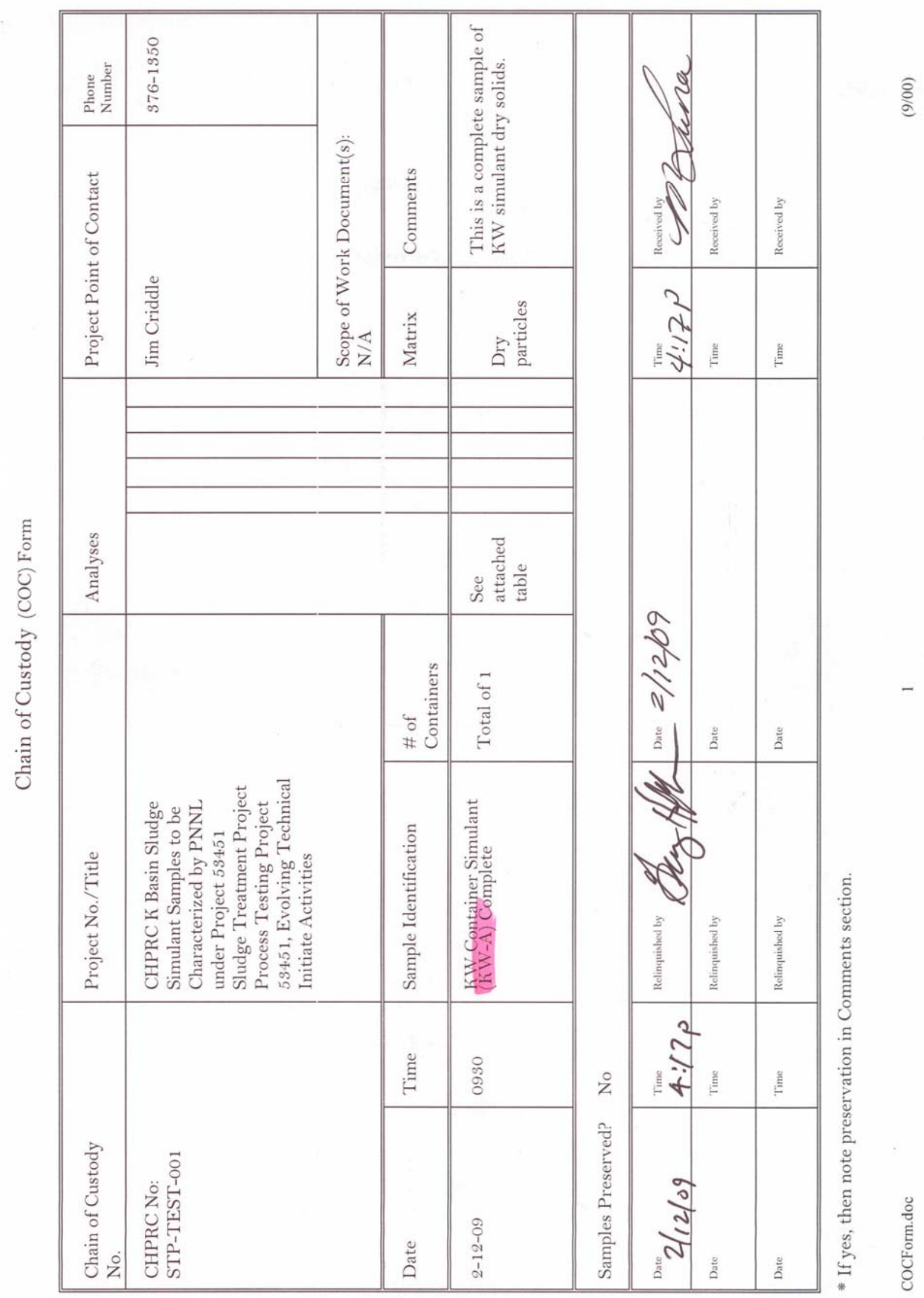

A. 16 
Characterization Approach for Simulant Confirmation

Attachment to $\mathrm{CoC}-1$

\begin{tabular}{|c|c|c|}
\hline Property/Parameter & $\begin{array}{c}\text { Measurement/Calculation } \\
\text { Approach }\end{array}$ & Frequency \\
\hline Settled Density & $\begin{array}{l}\text { Prep simulant with excess water, allow } \\
\text { sludge to settle for } 24 \mathrm{hr} \text {, measure volume } \\
\text { and mass. }\end{array}$ & Routine $^{(a)}$ \\
\hline $\begin{array}{l}\text { Wt \% Solids } \\
\text { (in settled sludge) }\end{array}$ & $\begin{array}{l}\text { Dry aliquot (known mass and volume) of } \\
\text { as-settled sludge at } 105^{\circ} \mathrm{C} \text {, measure mass, } \\
\text { and record dry bulk volume. }\end{array}$ & Routine $^{(a)}$ \\
\hline $\begin{array}{l}\text { Volume Fraction Water } \\
\text { (in settled sludge) }\end{array}$ & $\begin{array}{l}\text { Calculated from settled density and wt } \% \\
\text { solids. Assumption: all mass loss during } \\
\text { drying at } 105^{\circ} \mathrm{C} \text { is from loss of water }\end{array}$ & Routine $^{(a)}$ \\
\hline $\begin{array}{l}\text { Volume Fraction Solids } \\
\text { (in settled sludge) }\end{array}$ & Calculated from Volume Fraction Water & Routine $^{(a)}$ \\
\hline Settling Rate & Graduated cylinder and stop watch & Routine $^{(a)}$ \\
\hline \multirow{3}{*}{ Average Particle Density } & $\begin{array}{l}\text { Calculated from } \mathrm{W} \mathrm{t} \% \text { solids and } \mathrm{Vol} \\
\text { fraction solids }\end{array}$ & Routine $^{(a)}$ \\
\hline & $\begin{array}{l}\text { Calculated from vendor/handbook data } \\
\text { on simulant components and simulant } \\
\text { make up }\end{array}$ & Routine $^{(a)}$ \\
\hline & $\begin{array}{l}\text { Representative dry sample, density via } \\
\text { pycnometry }\end{array}$ & $\begin{array}{l}\text { As needed }{ }^{(b)}, \text { can be used to } \\
\text { confirm individual } \\
\text { components }\end{array}$ \\
\hline \multirow{3}{*}{ Particle Size Distribution } & $\begin{array}{l}\text { Calculated from vendor data on } \\
\text { components and simulant make up }\end{array}$ & Routine $^{(a)}$ \\
\hline & $<500 \mu \mathrm{m}$ - Particle size analyzer & Routine $^{(a)}$ \\
\hline & $\begin{array}{l}\text { Sieve full sample using the following } \\
\text { Sieves: } 2000 \mu \mathrm{m} \text { and } 500 \mu \mathrm{m}-\text { dry mass } \\
\text { of resulting three fraction }\end{array}$ & Routine $^{(\mathrm{a})}$ \\
\hline $\begin{array}{l}\text { Viscosity vs Shear Rate } \\
\text { Shear Stress vs. Shear Rate } \\
\text { (Rheograms) }\end{array}$ & $\begin{array}{l}<500 \mu \mathrm{m} \text { fraction: } \\
\text { Concentrations: as settled, } 75 \%, 50 \% \text { and } \\
25 \% \text { volume ratio of as settled }+ \text { water.. } \\
\text { Rheology of Each concentration will be } \\
\text { measured at } 55^{\circ} \mathrm{F} \text { and } 72^{\circ} \mathrm{F}\end{array}$ & Routine $^{(\mathrm{a})(\mathrm{c})}$ \\
\hline Shear strength & $\begin{array}{c}<500 \mu \mathrm{m} \text { fraction: } \\
\text { Settled sludge ( } 48 \text { to } 72 \text { hour gel time, } \\
\text { vane rheometer }\end{array}$ & Routine $^{(a)}$ \\
\hline \multicolumn{3}{|c|}{$\begin{array}{l}\text { (a) Routine - Recommend base characterization for all simulants. Significant data from actual sludge } \\
\text { exists for comparison. } \\
\text { (b) As needed - based on testing objectives for specific simulant, (note part of scope). } \\
\text { (c) There is a limited set of rheograms from actual sludge to compare to rheograms from simulants }\end{array}$} \\
\hline
\end{tabular}


KW Simulant Sample Batch - Not segregated (KW-A)

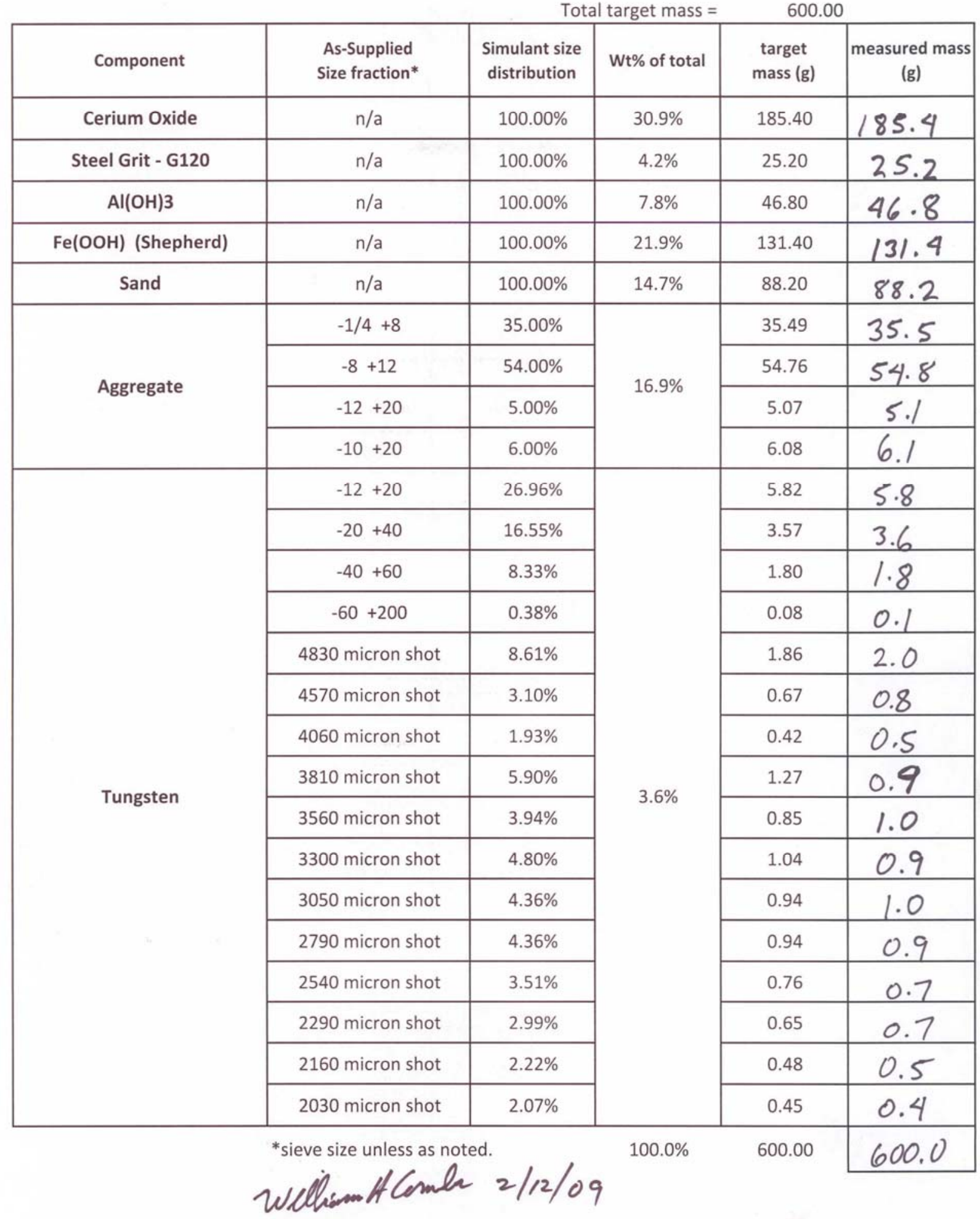




\begin{tabular}{|c|c|c|c|c|c|c|c|c|c|c|c|c|c|c|}
\hline 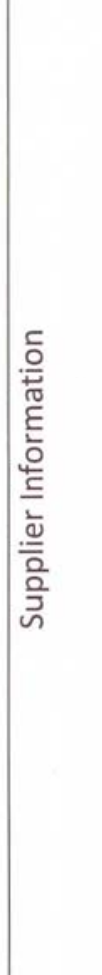 & 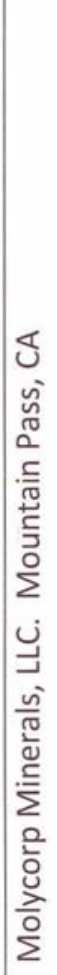 & 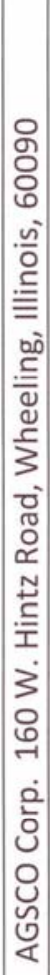 & 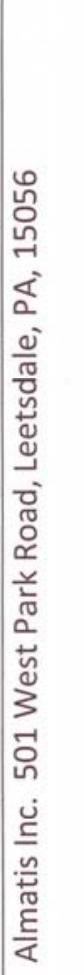 & 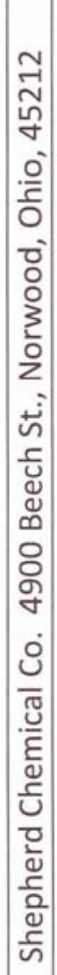 & 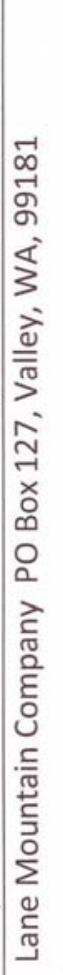 & 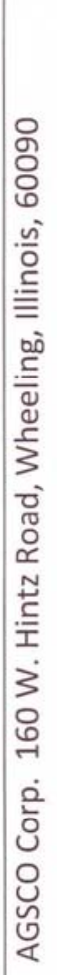 & 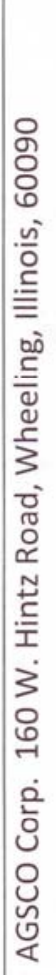 & 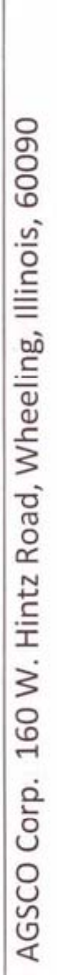 & 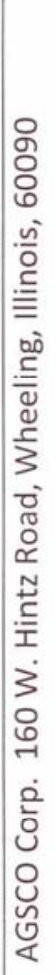 & 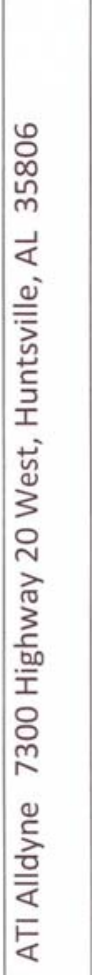 & 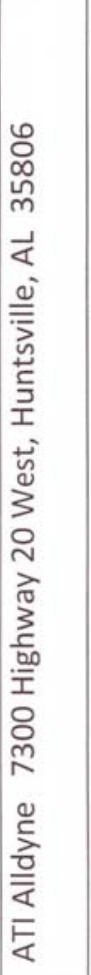 & 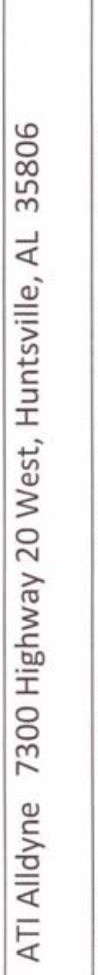 & 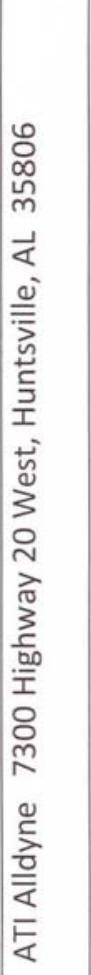 & 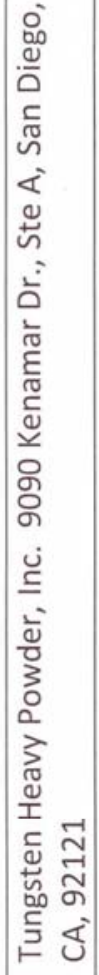 \\
\hline 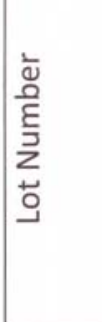 & 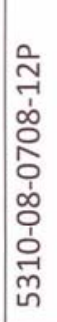 & 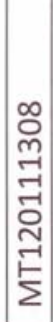 & 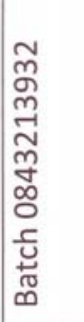 & 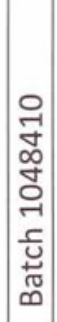 & ֻั & 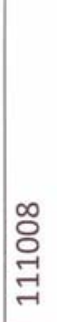 & $\begin{array}{l}\infty \\
\text { ర్ } \\
\text { ర్ }\end{array}$ & 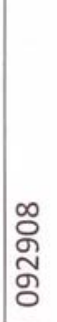 & $\begin{array}{l}\text { ○े } \\
\text { ஸू๊ }\end{array}$ & 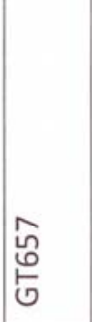 & \begin{tabular}{l}
$\infty$ \\
\multirow{J}{*}{} \\
$\stackrel{\bullet}{匕}$
\end{tabular} & 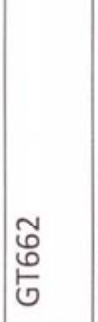 & 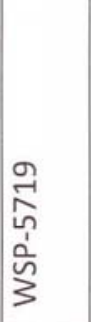 & 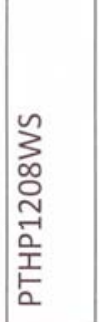 \\
\hline 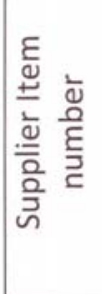 & 오 & 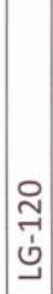 & 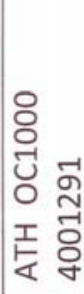 & 兄 & 焉 & 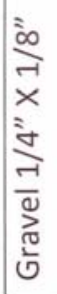 & 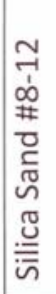 & 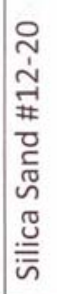 & 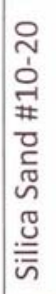 & $\begin{array}{l}m \\
\dot{0} \\
\infty \\
0 \\
0\end{array}$ & $\begin{array}{l}m \\
\stackrel{2}{2} \\
\infty \\
\infty \\
0\end{array}$ & $\begin{array}{l}+ \\
\dot{1} \\
\infty \\
\infty \\
0\end{array}$ & 离 & 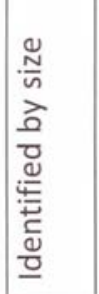 \\
\hline 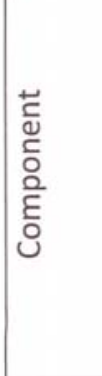 & 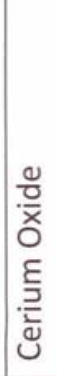 & 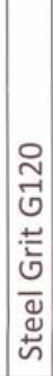 & $\frac{m}{\frac{m}{\widehat{T}}}$ & 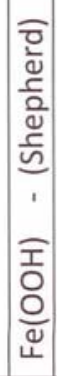 & 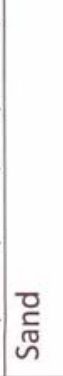 & 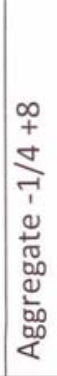 & 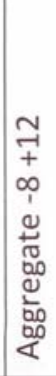 & 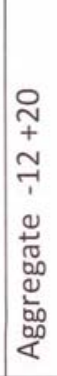 & 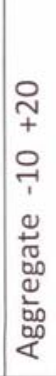 & 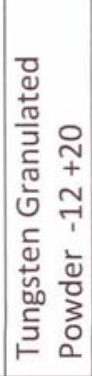 & 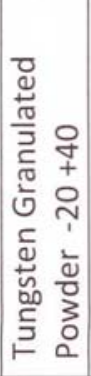 & 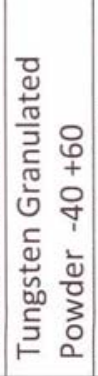 & 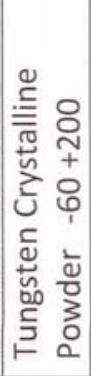 & 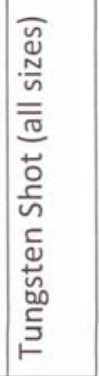 \\
\hline
\end{tabular}


Appendix B

\section{Particle-Size Distribution Data}




\section{Appendix B: Particle-Size Distribution Data}

Particle-size distributions (PSDs), (Volume), obtained for both the settler simulant, ST-A, and the KW-B M500 simulant are given in this section. The average PSD obtained with $75 \%$ sonication has been used throughout this report and discussed in Section 3.2.. The effects of both sonication and refractive index (RI) have been illustrated and are included along with the number average PSD for both simulants The KW-B M500 simulant was analyzed as received, a dry powder, and as the settled simulant; both sets of data are given here. A summary of the volume and number averages for the final PSD for each simulant is given below.

\begin{tabular}{|c|c|c|c|c|c|c|c|}
\hline PSD Run ID & Plot Type & RI & $\begin{array}{c}\text { Sonication } \\
\text { Power }\end{array}$ & $\begin{array}{c}\text { No of Runs } \\
\text { Averaged }\end{array}$ & $\mathrm{D} 10, \mu \mathrm{m}$ & $\mathrm{D} 50 \mu \mathrm{m}$ & $\mathrm{D} 90 \mu \mathrm{m}$ \\
\hline Settler Simulant-75 & Volume & 2.94 & 75 & 14 & 2.6 & 13.6 & 334 \\
\hline Settler Simulant-75 & Number & 2.94 & 75 & 14 & 0.35 & 0.53 & 1.2 \\
\hline KW-B M500-75 & Volume & 2.94 & 75 & 5 & 2.83 & 24.61 & 344 \\
\hline KW-B M500-75 & Number & 2.94 & 75 & 5 & 0.30 & 0.44 & 0.95 \\
\hline
\end{tabular}




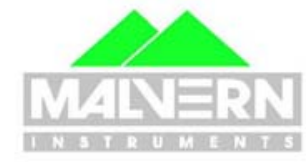

Sample Name:

Settler Simulant_ 4 aliquots

Settler Simulant ST-A
average PSD from obtained
from 4 sub samples

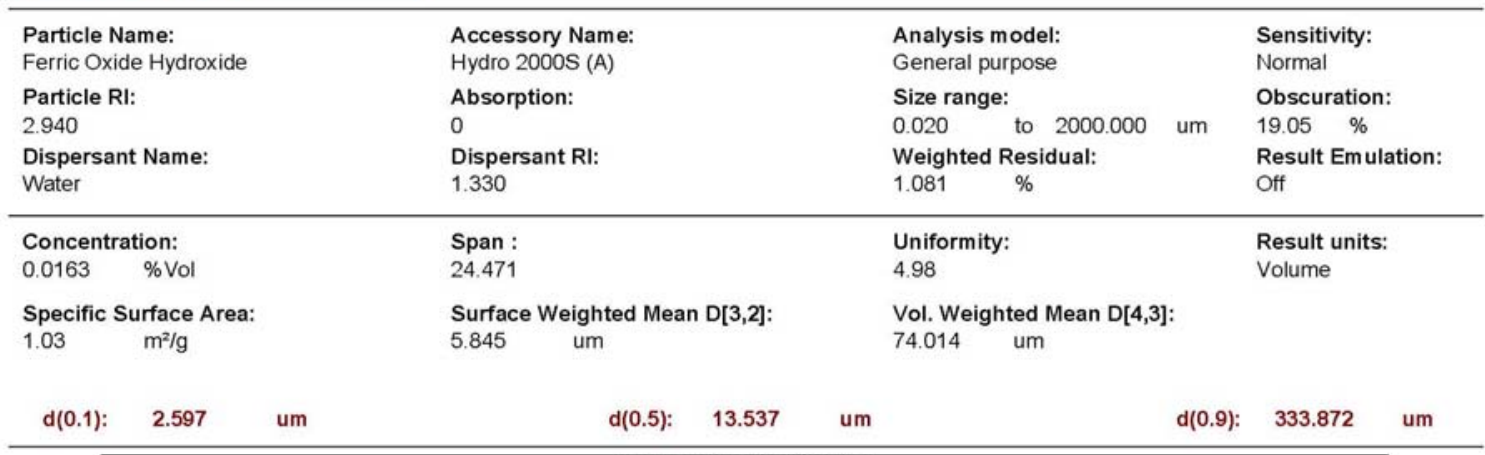

SOP Name:

Measured by:

d3m514

Result Source:

Averaged

\section{MASTERSIZER 2000}

\section{Result Analysis Report}

riday, March 27, 2009 2:14:38 PM

Analysed:

Friday, March 27, 2009 2:14:40 PM

Analysis model: Sensitivity

Weighted Residual: Result Emulation:

Uniformity: Result units:

Vol. Weighted Mean D[4,3]

4.014 um

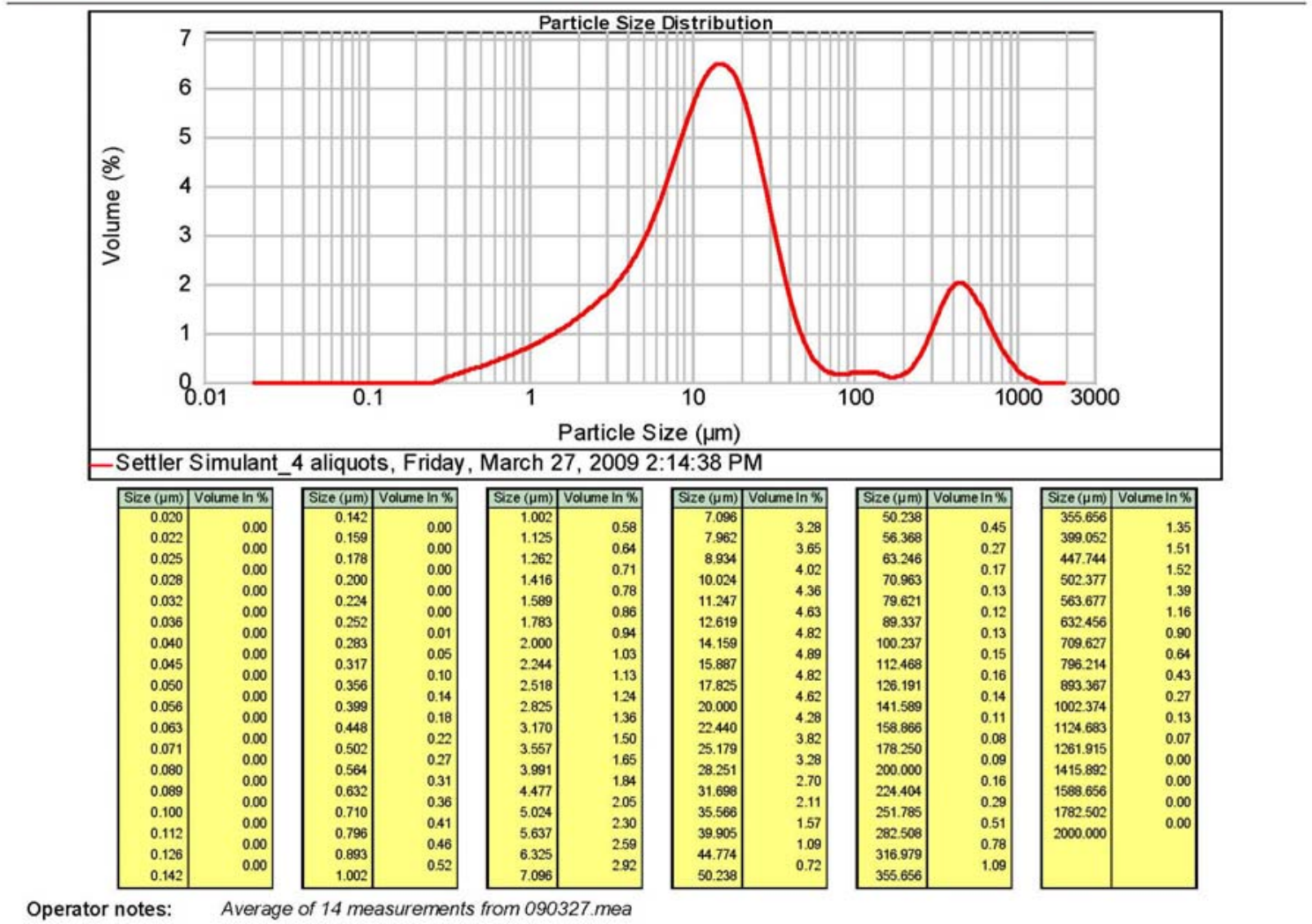

Operator notes: Average of 14 measurements from $090327 . \mathrm{mea}$ 


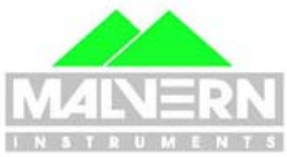

Sample Name

wet settler simulant ( $75 \%$ ) sonic Averaged

Settler Simulant ST-A,Sub-
samples used to calculate
average PSD

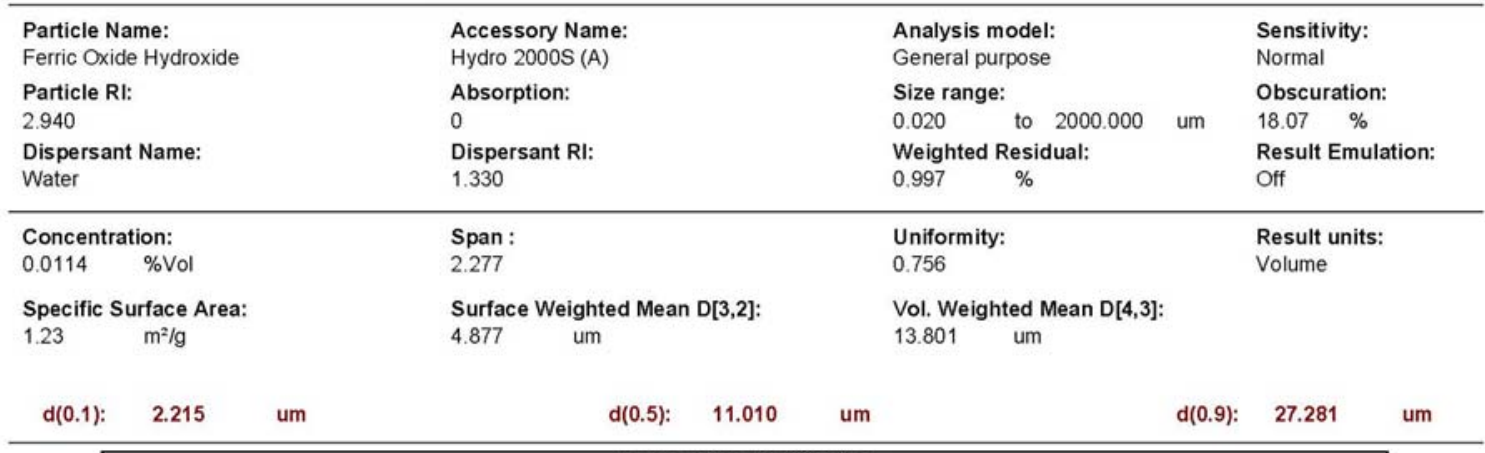

Wednesday, March 04, 2009 11:15:21 AM

Analysed:

Wednesday, April 29, 2009 5:33:39 PM

D3M514

Result Source:

Averaged

\section{Result Analysis Report}

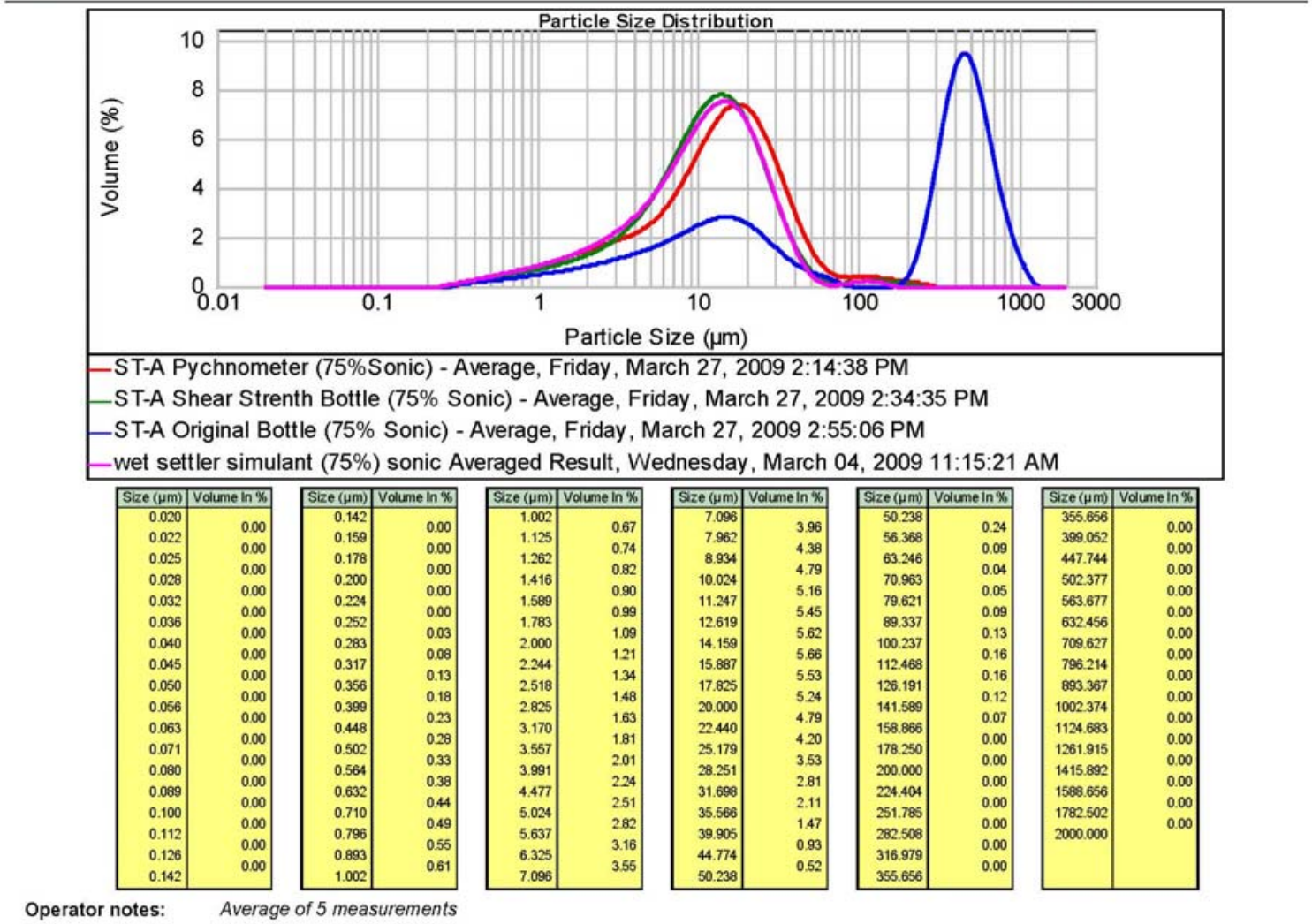




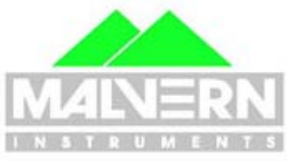

Sample Name: Wet Settler Simulant ( $75 \%$ Sonic) -

Sample Source \& type:

Settler Simulant ST-A, Effects of RI.

\section{MASTERSIZER 2000}

\section{Result Analysis Report}

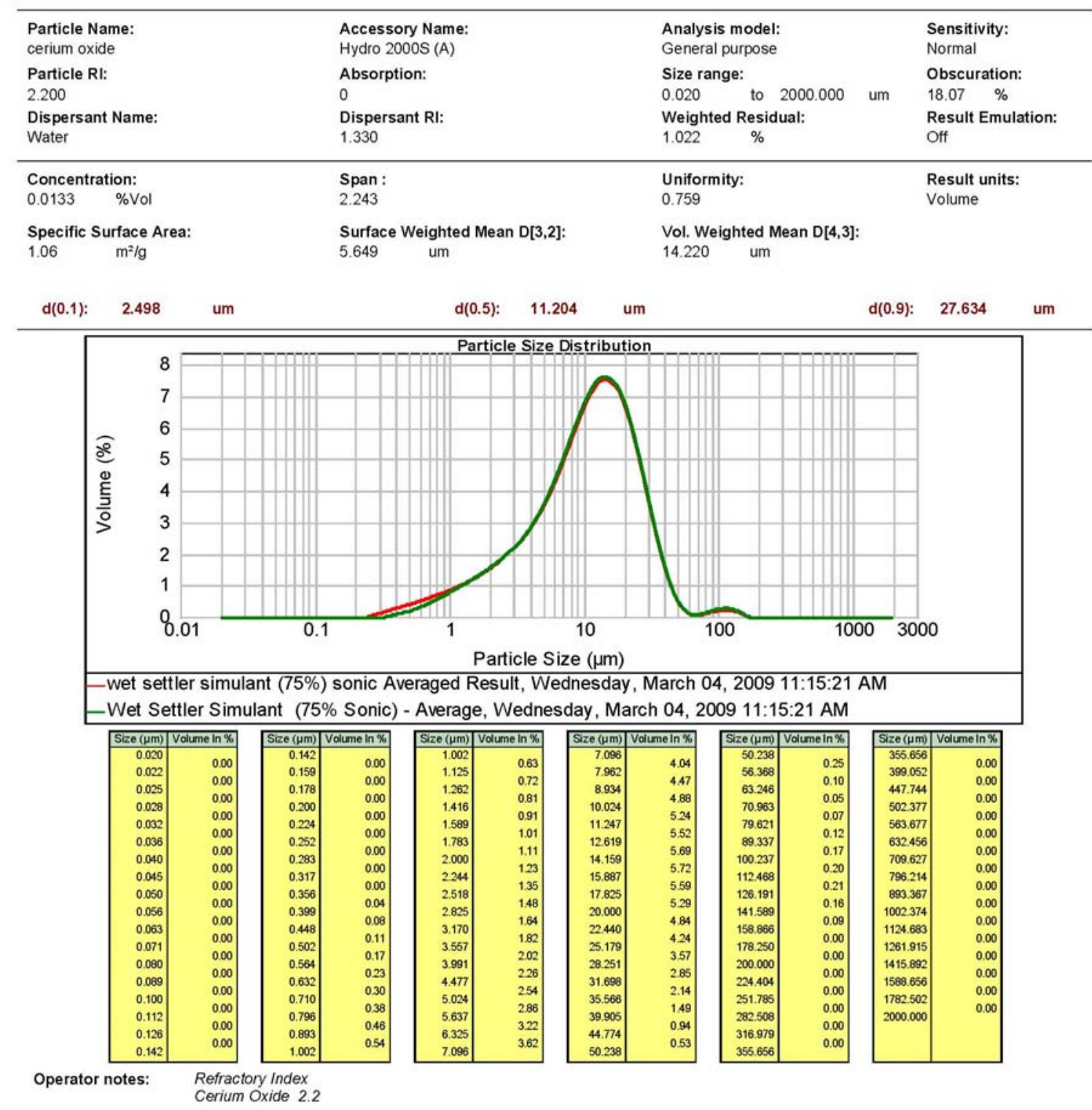

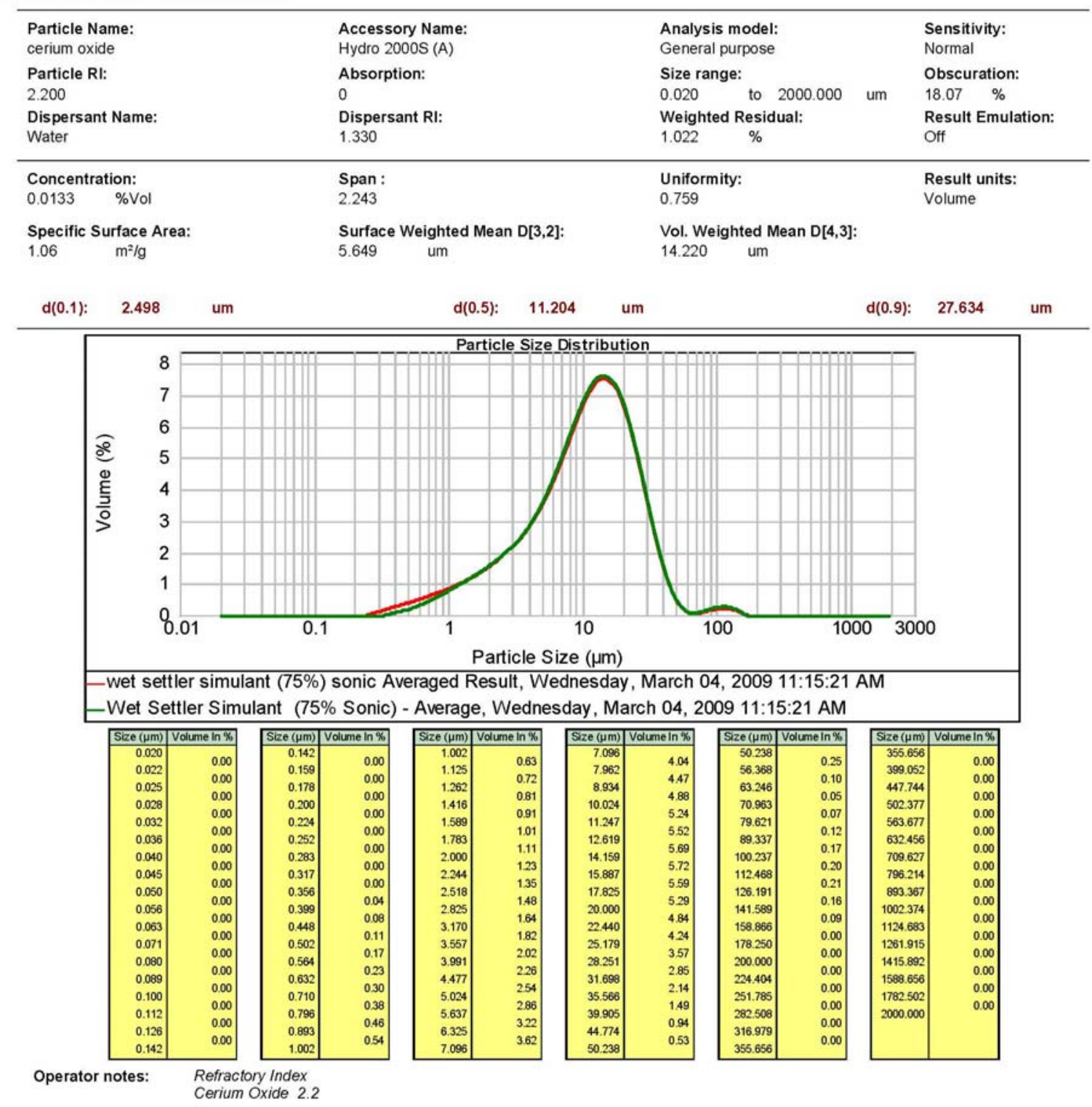

Wednesday, March 04, 2009 11:15:21 AM

\section{Analysed:}

Wednesday, March 04, 2009 11:15:22 AM

Result Source:

Result Sou

SOP Name:
Measured by:
D3M514
Result Source:
Averaged




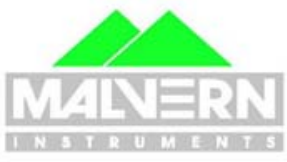

Sample Name: ST-A Original Bottle (Post Sonic) -

Sample Source \& type:

Settler Simulant ST-A, Effects of Sonication

\section{MASTERSIZER 2000}

\section{Result Analysis Report}

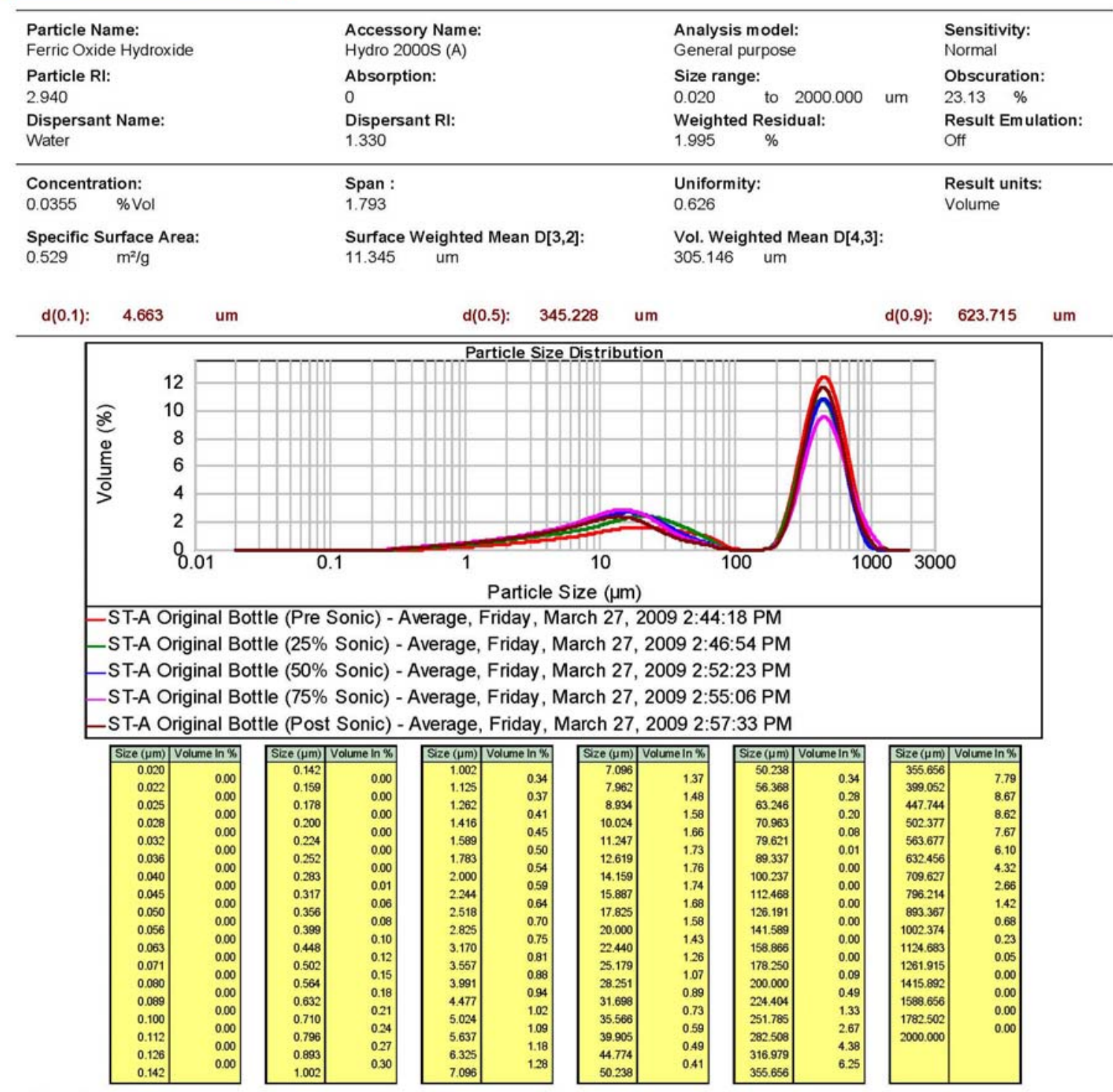

Operator notes: 


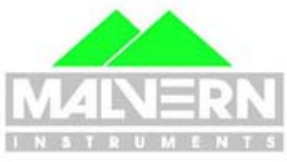

Sample Name: Settler Simulant (ST-A)_ $75 \%$ son_ Sample Source \& type: Settler Simulant, ST-A Number Averaged.

\section{MASTERSIZER 2000}

\section{Result Analysis Report}

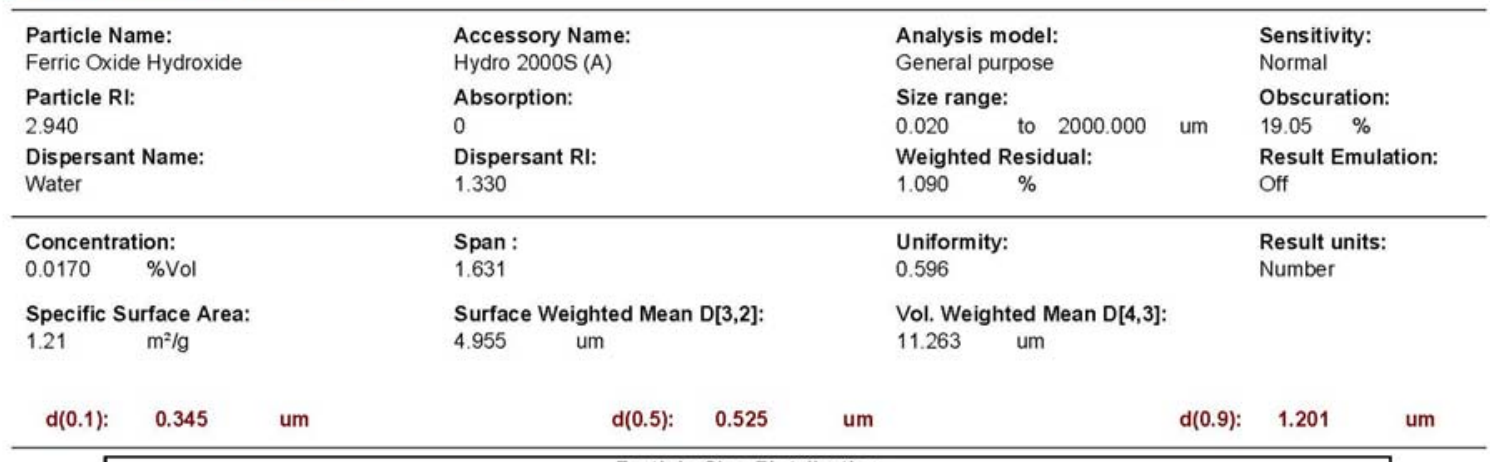

Friday, March 27, 2009 2:14:38 PM

Analysed:

Monday, April 27, 2009 12:36:14 AM

d3m514

Result Source:

Averaged

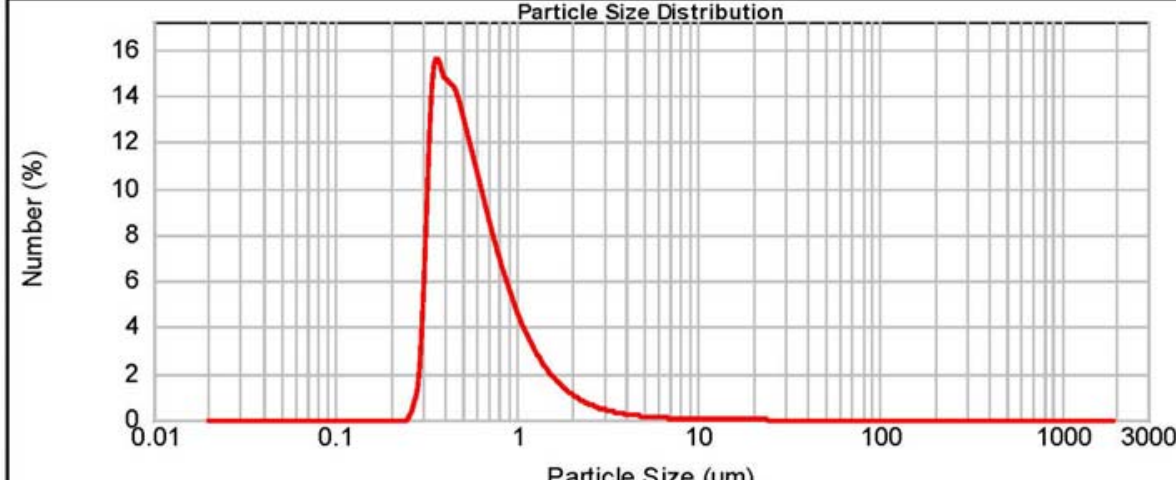

Particle Size $(\mu \mathrm{m})$

\begin{tabular}{|c|c|c|c|c|c|c|c|c|c|c|c|}
\hline Szze $(\mu \mathrm{m})$ & Number In $\%$ & Size $(\mu \mathrm{m})$ & Number in $\%$ & Szze $(\mu \mathrm{m})$ & Number $\ln \%$ & $\widehat{S i z e(\mu m)}$ & Number $\ln \%$ & Szze ( $(\mu \mathrm{m})$ & Number $\ln \%$ & Size $(\mu \mathrm{m})$ & Number in $\%$ \\
\hline 0.020 & & 0.142 & 000 & 1.002 & & 7.096 & 005 ] & 50.238 & 000 & 355.656 & 000 \\
\hline 0.022 & 0.00 & 0.159 & 000 & 1.125 & $\begin{array}{l}3.14 \\
251\end{array}$ & 7.962 & 0.05 & 56.368 & 0.00 & 399.052 & 0.00 \\
\hline 0.025 & 0.00 & 0.178 & 0.000 & 1.262 & 2.51 & 8.934 & 0.04 & 63.246 & 0.00 & 447.744 & 0.00 \\
\hline 0.028 & & 0.200 & 0.000 & 1.416 & 1.08 & 10.024 & 0.03 & 70.963 & 0.00 & 502.377 & 0.00 \\
\hline 0.032 & 0.00 & 0.224 & 0.00 & 1.589 & 1.55 & 11.247 & 0.02 & 79.621 & 0.00 & 563.677 & 0.00 \\
\hline 0.036 & 0.00 & 0.252 & 0.00 & 1.783 & 1.21 & 12.619 & 0.02 & 89.337 & 0.00 & 632456 & 0.00 \\
\hline 0.040 & 0.00 & 0.283 & 0.34 & 2000 & 0.94 & 14.159 & 0.01 & 100.237 & 0.00 & 709627 & 0.00 \\
\hline 0.045 & 0.00 & 0.317 & 238 & 2244 & 0.73 & 15.887 & 0.01 & 112.468 & 0.00 & 796214 & 0.00 \\
\hline 0.050 & 0.00 & 0.356 & 10.58 & 2518 & 0.57 & 17.825 & 0.01 & 126.191 & 0.00 & 893367 & 0.00 \\
\hline 0.056 & 0.00 & 0.399 & 11.53 & 2.825 & 0.44 & 20.000 & 0.00 & 141.589 & 0.00 & 1002374 & 0.00 \\
\hline 0.063 & 0.00 & 0.448 & 10.98 & 3.170 & 0.34 & 22440 & 0.01 & 158.866 & 0.00 & 1124688 & 0.00 \\
\hline 0.071 & 0.00 & 0.502 & 10.48 & 3.557 & 0.27 & 25.179 & 0.00 & 178.250 & 0.00 & 1261915 & 0.00 \\
\hline 0.080 & 0.00 & 0.564 & 9.35 & 3.991 & 0.21 & 28251 & 0.00 & 200.000 & 0.00 & 1201599 & 0.00 \\
\hline 0.089 & 0.00 & 0.632 & 8.17 & 4.477 & 0.16 & 31.698 & 0.00 & 224404 & 0.00 & 1583656 & 0.00 \\
\hline 0.100 & 0.00 & 0.710 & 6.98 & 5.024 & 0.13 & 35566 & 0.00 & 251.785 & 0.00 & 1782502 & 0.00 \\
\hline 0.112 & 0.00 & 0.796 & 5.84 & 5.637 & 0.10 & 39.905 & 0.00 & 282.508 & 0.00 & & 0.00 \\
\hline 0.126 & 0.00 & 0.893 & 4.81 & 6.325 & 0.08 & 44.774 & 0.00 & 316.979 & 0.00 & & \\
\hline 0.142 & 0.00 & 1.002 & 3.91 & 7.096 & 0.07 & 50.238 & 0.00 & 355.656 & 0.00 & & \\
\hline
\end{tabular}

Operator notes:

Average of 14 measurements from 4 different samples at $75 \%$ sonication 


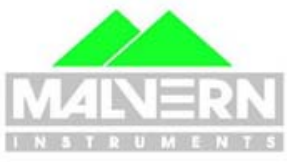

Sample Name: Settled KW-B M500 (75\% Sonic) - Average

Sample Source \& type:

KW_B M500 Data used in Report

Particle Name:

Ferric Oxide Hydroxide

Particle RI:

2.940

Dispersant Name:

Water

Concentration:

$0.0179 \%$ Vol

Specific Surface Area:

$0.887 \quad \mathrm{~m}^{2} / \mathrm{g}$

$d(0.1): \quad 2.823 \quad$ um
Measured by: D3M514

Result Source:

Averaged

\section{Result Analysis Report}

\section{MASTERSIZER 2000}

Measured:

Measured:
Monday, March 02, 2009 3:37:08 PM

Analysed:

Monday, March 02, 2009 3:37:09 PM

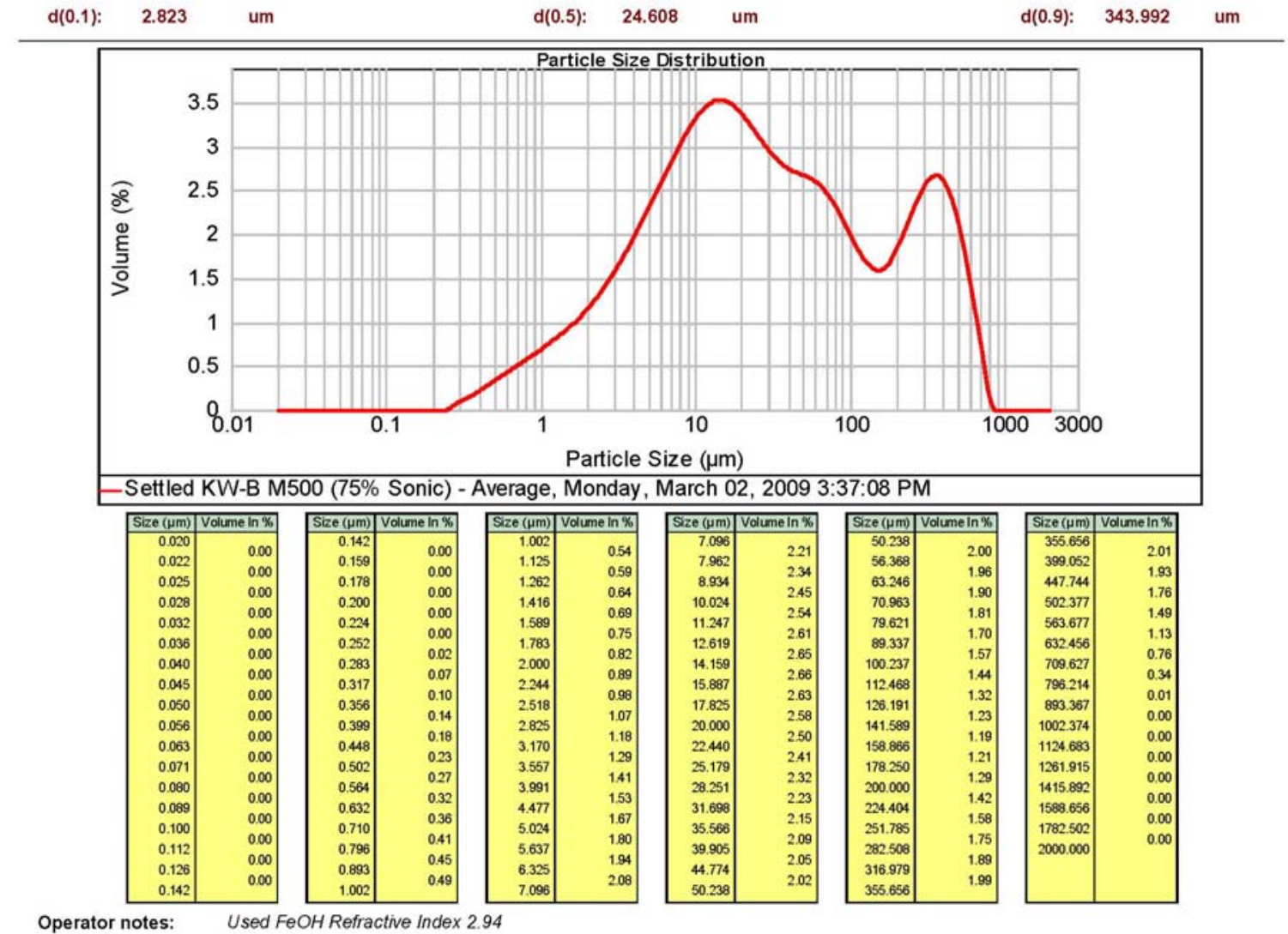

Operator notes:

\begin{tabular}{|c|c|c|}
\hline $\begin{array}{l}\text { Accessory Name: } \\
\text { Hydro } 2000 \text { S (A) }\end{array}$ & $\begin{array}{l}\text { Analysis model: } \\
\text { General purpose }\end{array}$ & $\begin{array}{l}\text { Sensitivity: } \\
\text { Normal }\end{array}$ \\
\hline Absorption: & Size range: & Obscuration: \\
\hline 0 & 0.020 to 2000.000 & $20.37 \%$ \\
\hline $\begin{array}{l}\text { Dispersant RI: } \\
1.330\end{array}$ & $\begin{array}{l}\text { Weighted Residual: } \\
0.391 \quad \%\end{array}$ & $\begin{array}{l}\text { Result Emulation: } \\
\text { Off }\end{array}$ \\
\hline $\begin{array}{l}\text { Span : } \\
13.864\end{array}$ & $\begin{array}{l}\text { Uniformity: } \\
3.62\end{array}$ & $\begin{array}{l}\text { Result units: } \\
\text { Volume }\end{array}$ \\
\hline Surface Weighted Mean $D[3,2]$ : & Vol. Weighted Mean D[4,3]: & \\
\hline
\end{tabular}

Surface Weighted Mean D[3,2]: $\quad$ Vol. Weighted Mean D[4,3]:

98.370 um 


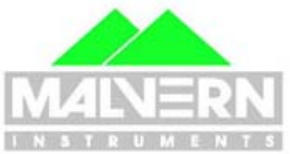

\section{MASTERSIZER 2000}

\section{Result Analysis Report}

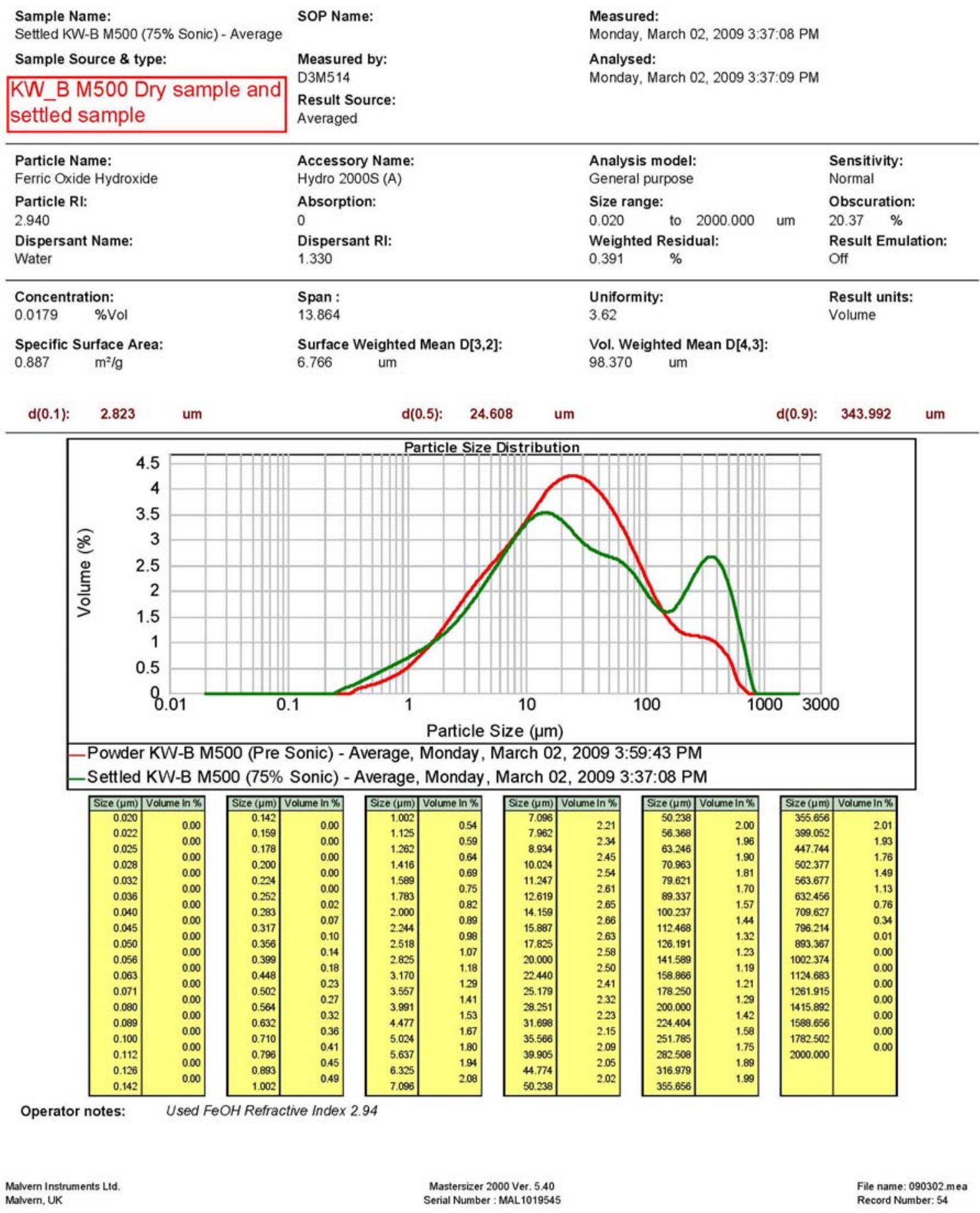




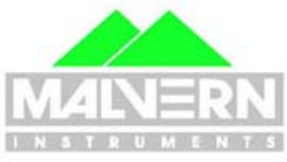

Sample Name: Settled KW-B M500 (75\% Sonic) - Average

Sample Source \& type:

KW_B M500 Effects of RI.

\section{MASTERSIZER 2000}

\section{Result Analysis Report}

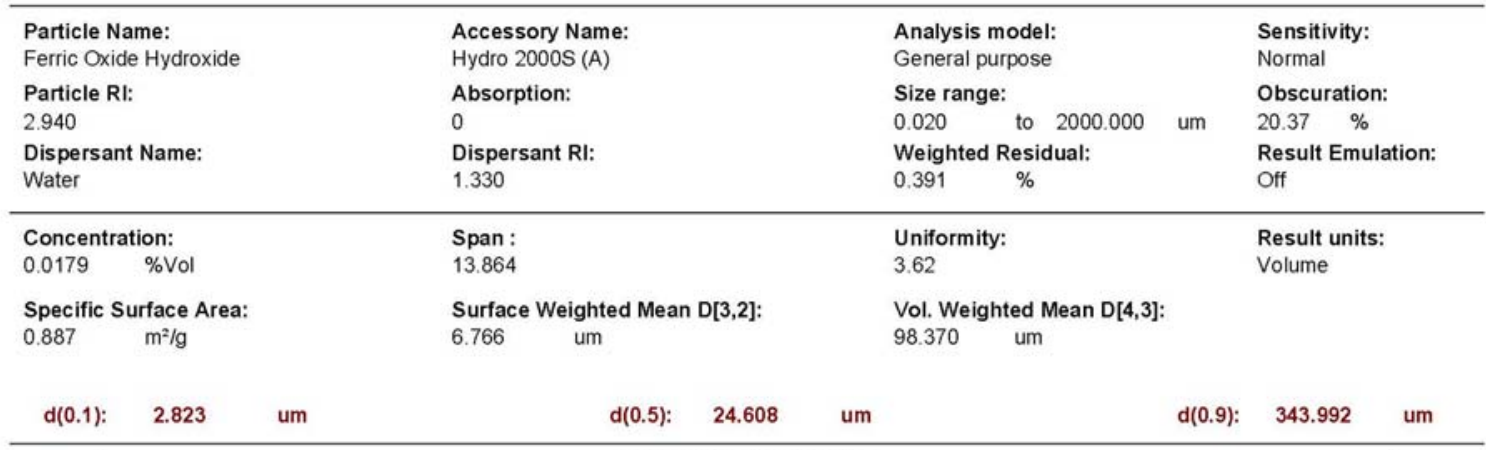

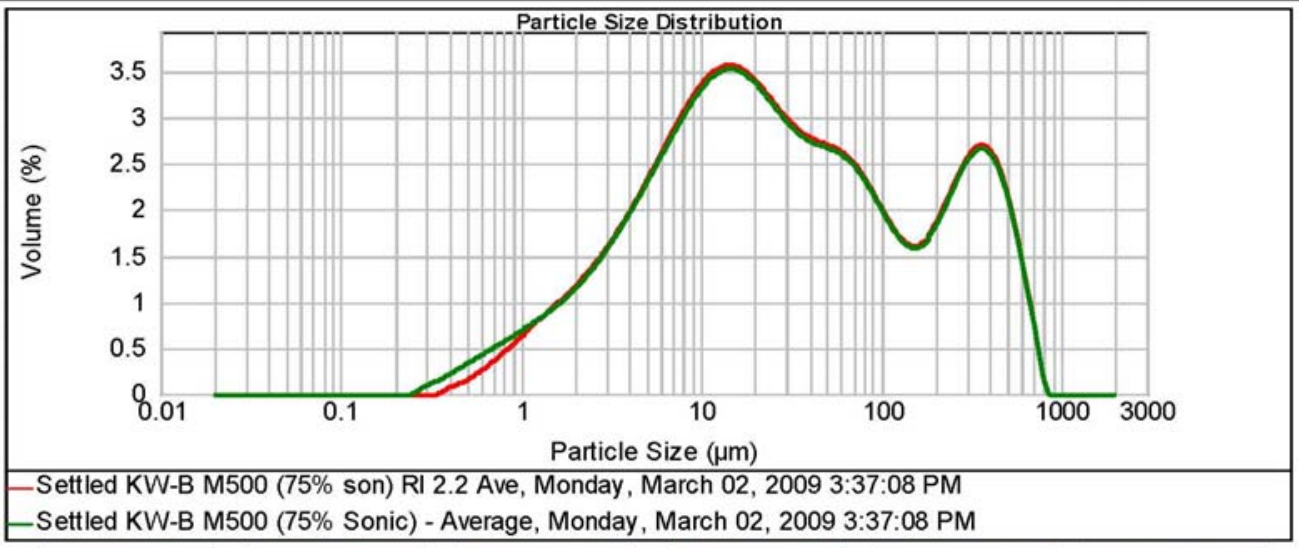

\begin{tabular}{|c|c|c|c|c|c|c|c|c|c|c|c|}
\hline $\operatorname{Szze}(\mu \mathrm{m})$ & Volume in $\%$ & Size ( $(\mu \mathrm{m})$ & Volume $\ln \%$ & Size ( $\mu \mathrm{m})$ & Volume in \% & Size $(\mu \mathrm{m})$ & Volume In $\%$ & Size $(\mu \mathrm{m})$ & Volume In $\%$ & Size $(\mu \mathrm{m})$ & Volume in $\%$ \\
\hline 0.020 & & 0.142 & & 1.002 & & 7.096 & & 50.238 & & 355.656 & 201 \\
\hline 0.022 & . & 0.159 & 0 & 1.125 & 0.54 & 7.962 & 2.21 & 56.368 & 200 & 399.052 & 20 \\
\hline 0.025 & 0.00 & 0.178 & 0.00 & 1.262 & 0.59 & 8.934 & 2.34 & 63.246 & 1.96 & 447.744 & 1.93 \\
\hline 0.028 & 0.00 & 0.200 & 0.00 & 1.416 & 0.64 & 10.024 & 2.45 & 70.963 & 1.90 & 502377 & 1.76 \\
\hline 0.032 & 0.00 & 0.224 & 0.00 & 1.589 & 0.69 & 11.247 & 2.54 & 79.621 & 1.81 & 563.677 & 1.49 \\
\hline 0.036 & 0.00 & 0.252 & 0.00 & 1.783 & 0.75 & 12.619 & 2.61 & 89.337 & 1.70 & 632.456 & 1.13 \\
\hline 0.040 & 0.00 & 0.283 & 0.02 & 2.000 & 0.82 & 14.159 & 2.65 & 100.237 & 1.57 & 709.627 & 0.76 \\
\hline 0.045 & 0.00 & 0.317 & 0.07 & 2.244 & 0.89 & 15.887 & 2.66 & 112.468 & 1.44 & 796.214 & 0.34 \\
\hline 0.050 & 0.00 & 0.356 & 0.10 & 2.518 & 0.98 & 17.825 & 2.63 & 126.191 & 1.32 & 893.367 & 0.01 \\
\hline 0.056 & 0.00 & 0.399 & 0.14 & 2.825 & 1.07 & 20.000 & 2.58 & 141.589 & 1.23 & 1002.374 & 0.00 \\
\hline 0.063 & 0.00 & 0.448 & 0.18 & 3.170 & 1.18 & 22.440 & 2.50 & 158.866 & 1.19 & 1124.683 & 0.00 \\
\hline 0.071 & 0.00 & 0.502 & 0.23 & 3.557 & 1.29 & 25.179 & 241 & 178.250 & 1.21 & 1281915 & 0.00 \\
\hline 0.080 & 0.00 & 0.564 & 0.27 & 3.991 & 141 & 28.251 & 2.32 & 200.000 & 1.29 & 1415.892 & 0.00 \\
\hline 0.089 & 0.00 & 0.632 & 0.32 & 4.477 & 1.53 & 31.698 & 2.23 & 224.404 & 1.42 & 1506656 & 0.00 \\
\hline 0.100 & 0.00 & 0.710 & 0.36 & 5.024 & 1.67 & 35.566 & 2.15 & 251.785 & 1.58 & 1782502 & 0.00 \\
\hline 0.112 & 0.00 & 0.796 & 0.41 & 5.637 & 1.80 & 39.905 & 2.09 & 282.508 & 1.75 & 2000.000 & 0.00 \\
\hline 0.126 & 0.00 & 0.893 & 0.45 & 6.325 & 1.94 & 44.774 & 2.05 & 316.979 & 1.89 & & \\
\hline 0.142 & 0.00 & 1.002 & 0.49 & 7.096 & 200 & 50.238 & 2.02 & 355.656 & 1.99 & & \\
\hline
\end{tabular}

Operator notes:

SOP Name:

Measured by:

D3M514

Result Source:

Averaged
Monday, March 02, 2009 3:37:08 PM

Analysed:

Monday, March 02, 2009 3:37:09 PM 


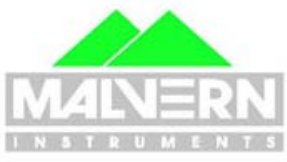

Sample Name: Settled KW-B M500 (Post Sonic) - Average

Sample Source \& type:

KW_B M500 Effects of sonication

\section{MASTERSIZER 2000}

\section{Result Analysis Report}

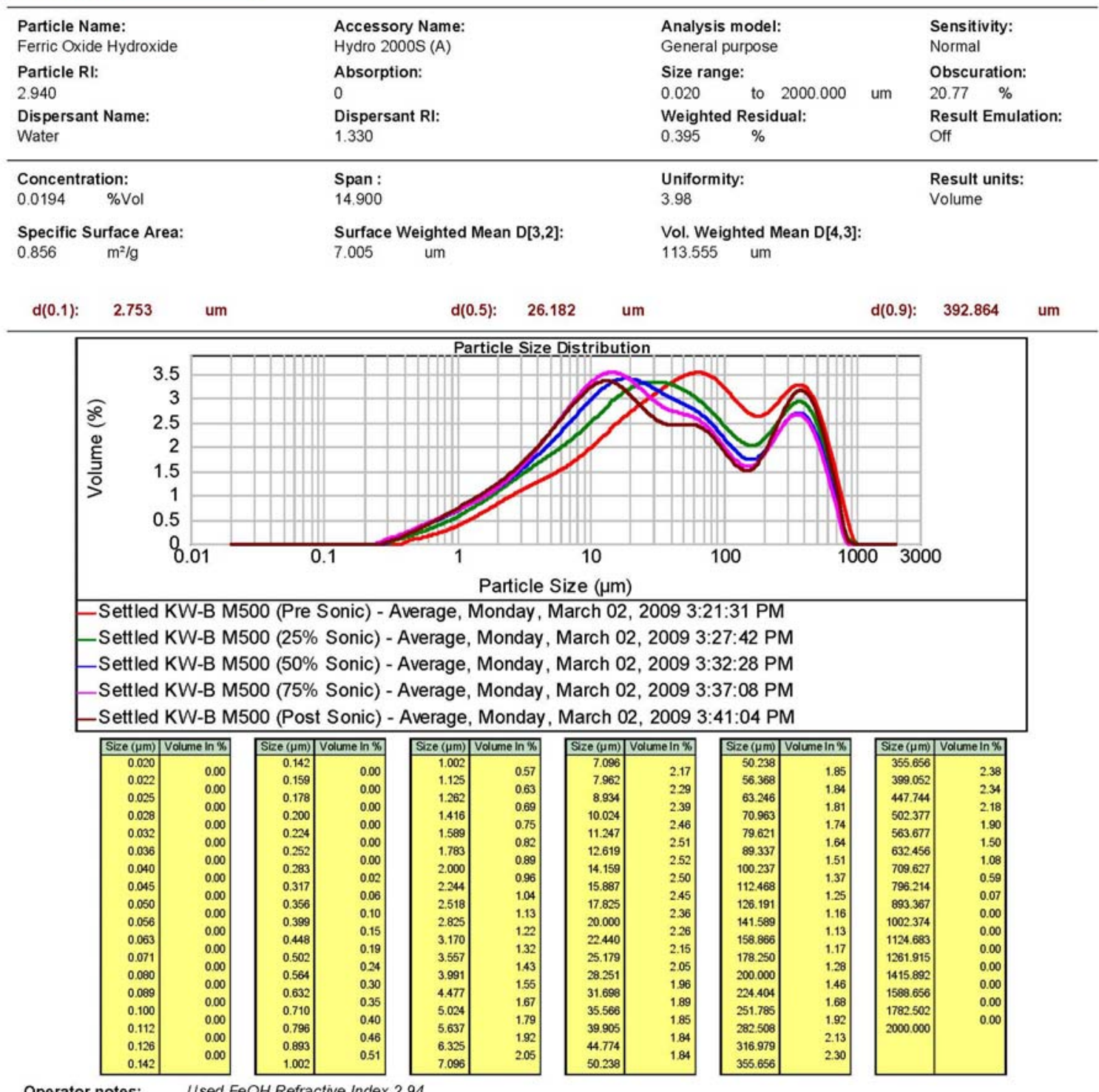

Operator notes:

SOP Name:

Measured by:

D3M514

Result Source:

Averaged
Measured:

Monday, March 02, 2009 3:41:04 PM

Analysed:

Monday, March 02, 2009 3:41:05 PM 


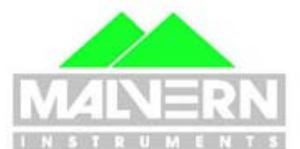

Sample Name:

KW-B M500 75\% son Number Averaged

Sample Source \& type:

KW_B M500 Number Averaged.

\section{MASTERSIZER 2000}

\section{Result Analysis Report}

SOP Name:

Measured by:

D3M514

Result Source: Averaged

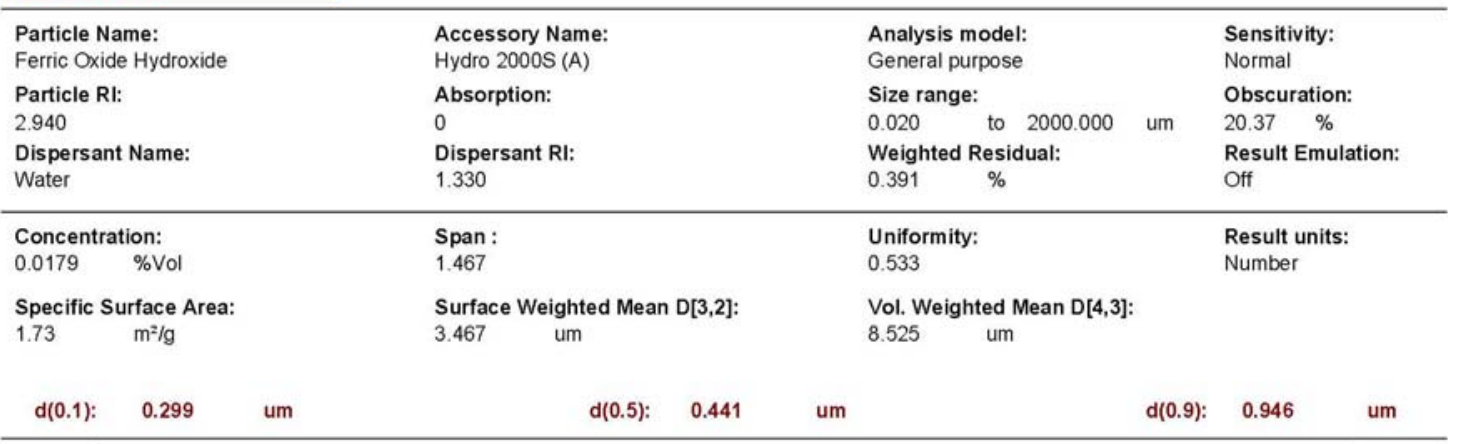

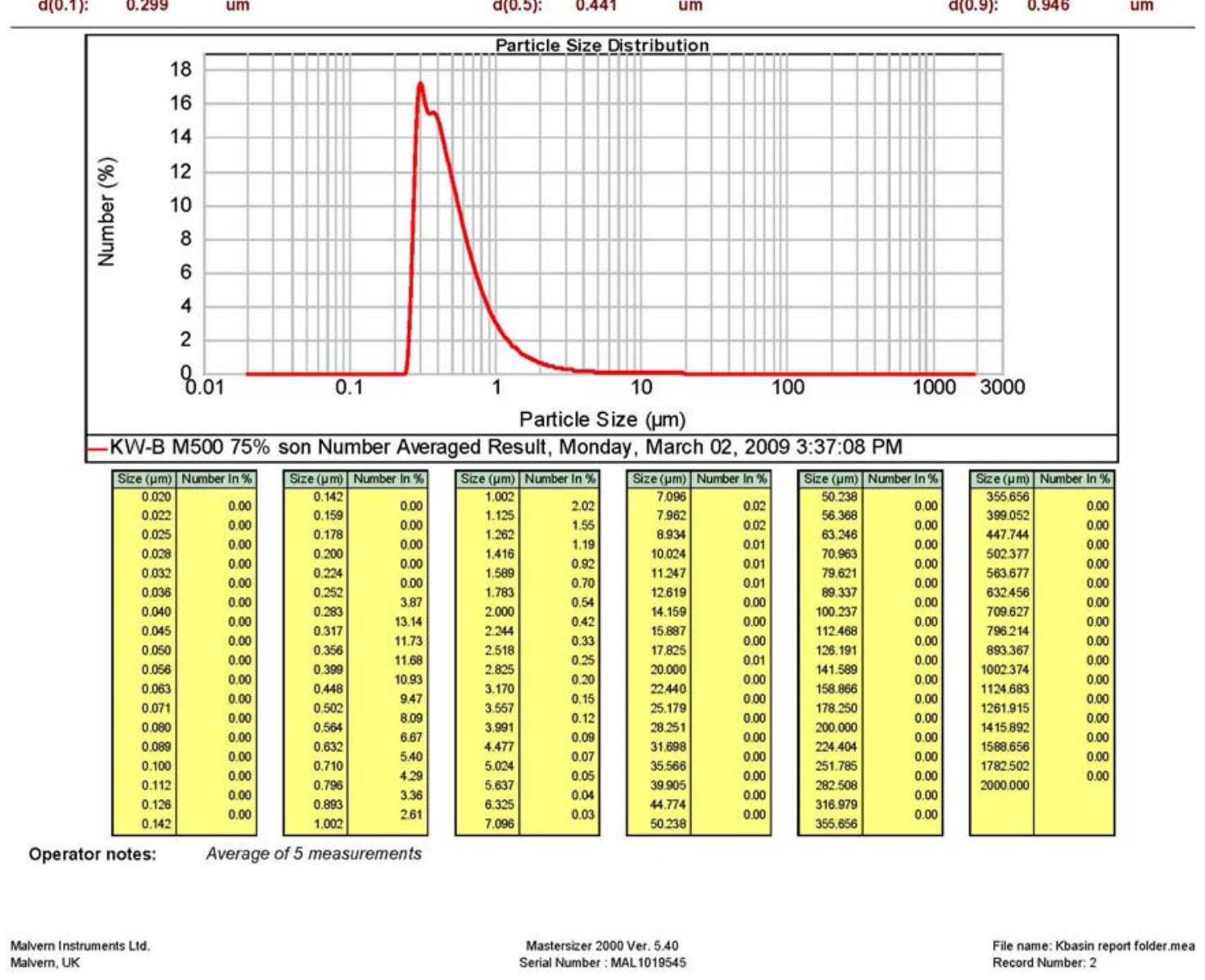

Measured:

Monday, March 02, 2009 3:37:08 PM

Analysed:

Monday, April 27, 2009 2:33:27 AM 


\section{Appendix C}

\section{Shear Strength vs. Time and Rheograms}




\section{Appendix C: Rheology Plots}

Shear-strength values were obtained from stress/time profiles that are given in this appendix. The flow curves used to obtain yield stress and viscosity values for both simulants are also included along with their corresponding viscosity plots (triplicate analysis). All data have been discussed and summarized in Section 3.3. 


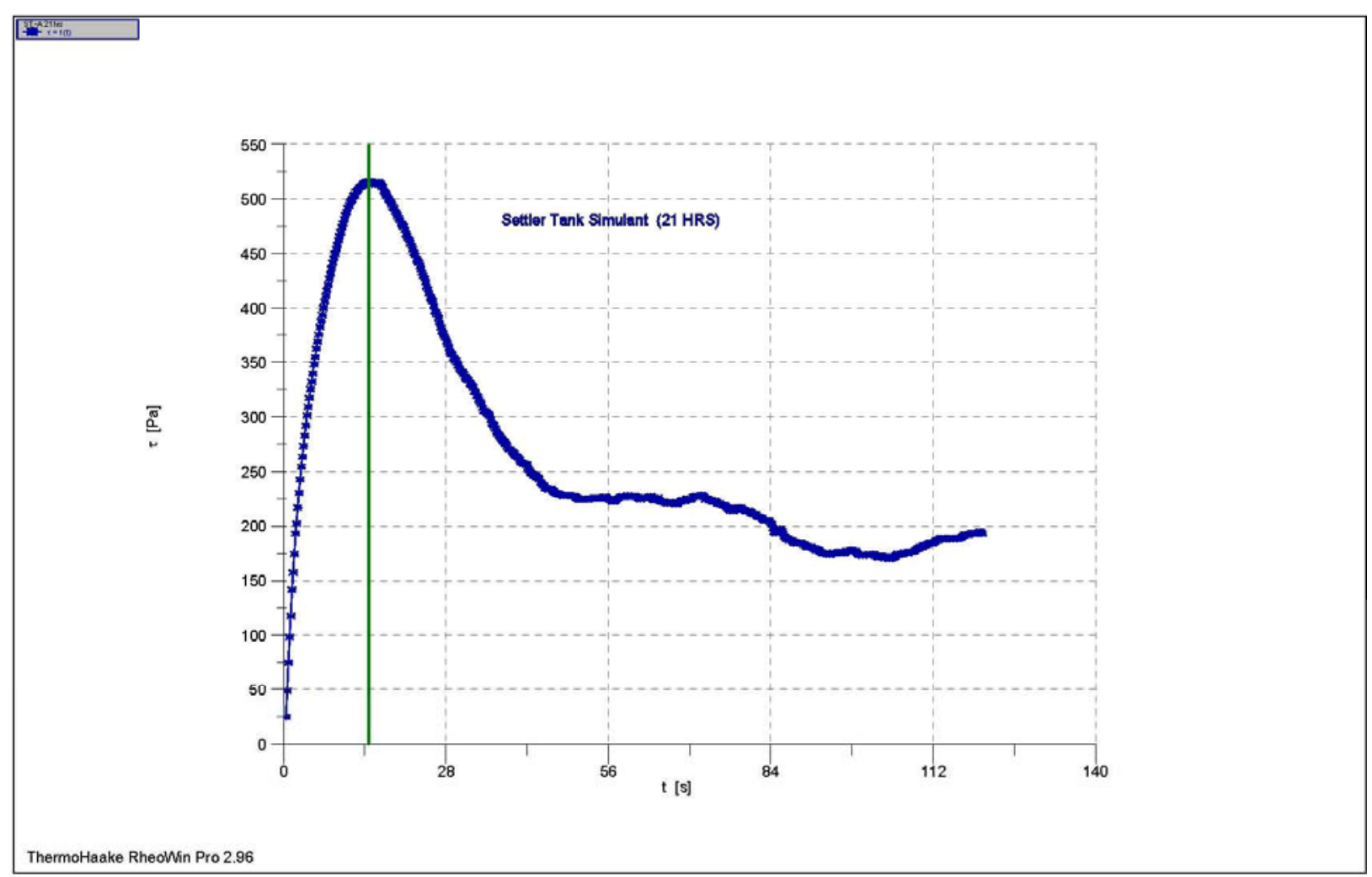

1: C:IRheologv Results 153019 -M12IShear Strength $1.6 \times 1.6 \mathrm{~cm}$ VanelST -A $21 \mathrm{hrs} . \mathrm{rwd}$ Company / Operator: PNNL / MARIA LUNA

Date / Time / Version: 03.03.2009 / 13:04:34 PM / RheoWin Pro 296

Substance / Sample no: 090303 Settler Tank Simulant 21 hrs / ST -A $21 \mathrm{hrs}$

Curve discussion: Greatest value $\mathrm{t}[\mathrm{s}] 14.67 \tau[\mathrm{Pa}] 516.4$ 
ThermoHaake RheoWin 3/11/2009 / 3:28 PM

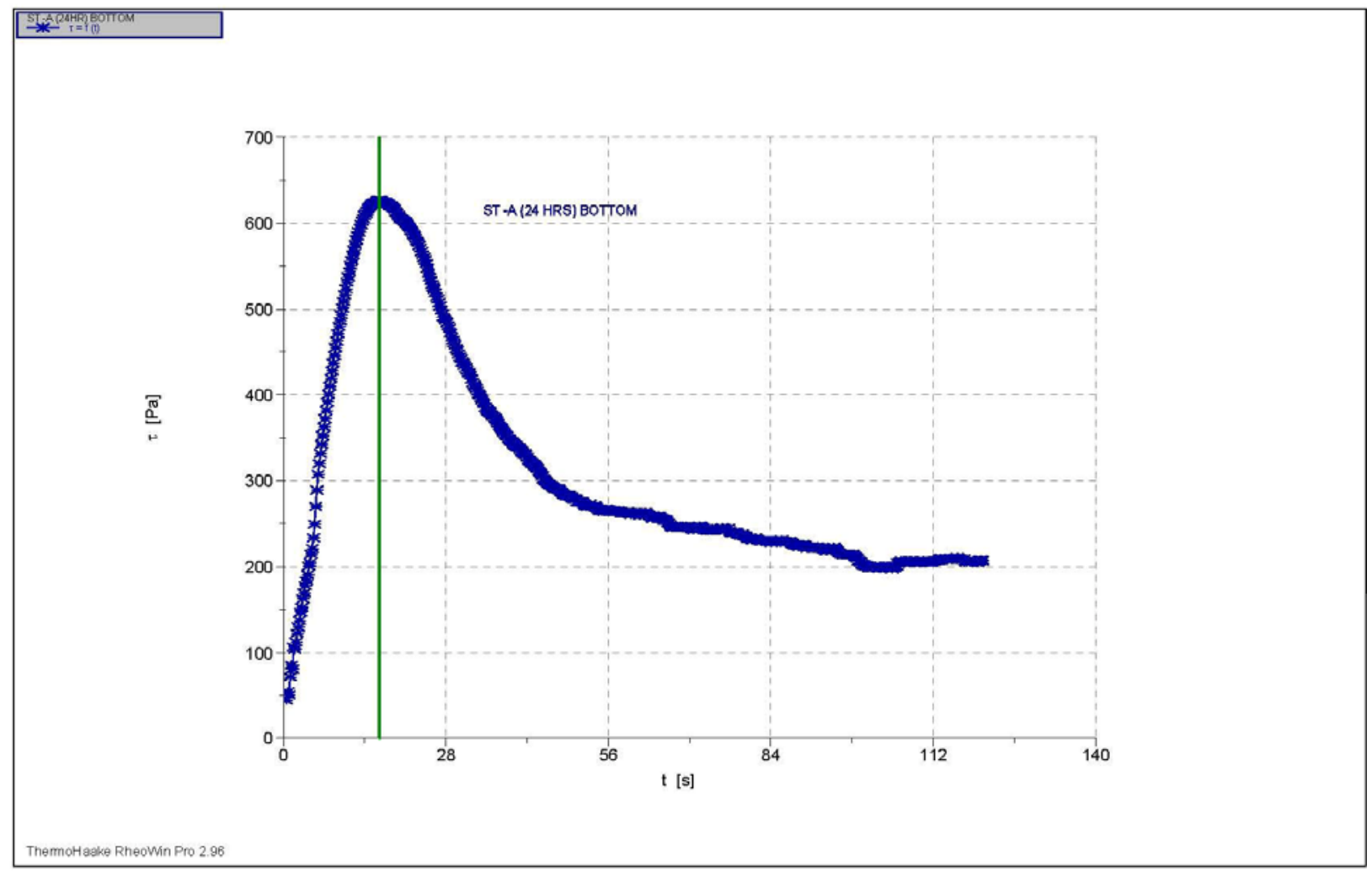

1: C:IRheology Results\K-Basin IShear Strength (vane)\ST -A (24HR) BOTTOM.rwd

Company / Operator: PNNL / MARIA LUNA

Date / Time / Version: 11.03.2009 / 15:24:28 PM / RheoWin Pro 296

Substance / Sample no: ST -A (24HR) / ST -A (24HR)

Curve discussion: Greatest value $\mathrm{t}[\mathrm{s}] 16.56 \tau[\mathrm{Pa}] 627.3$ 
ThermoHaake RheoWin 3/5/2009 / 4:11 PM

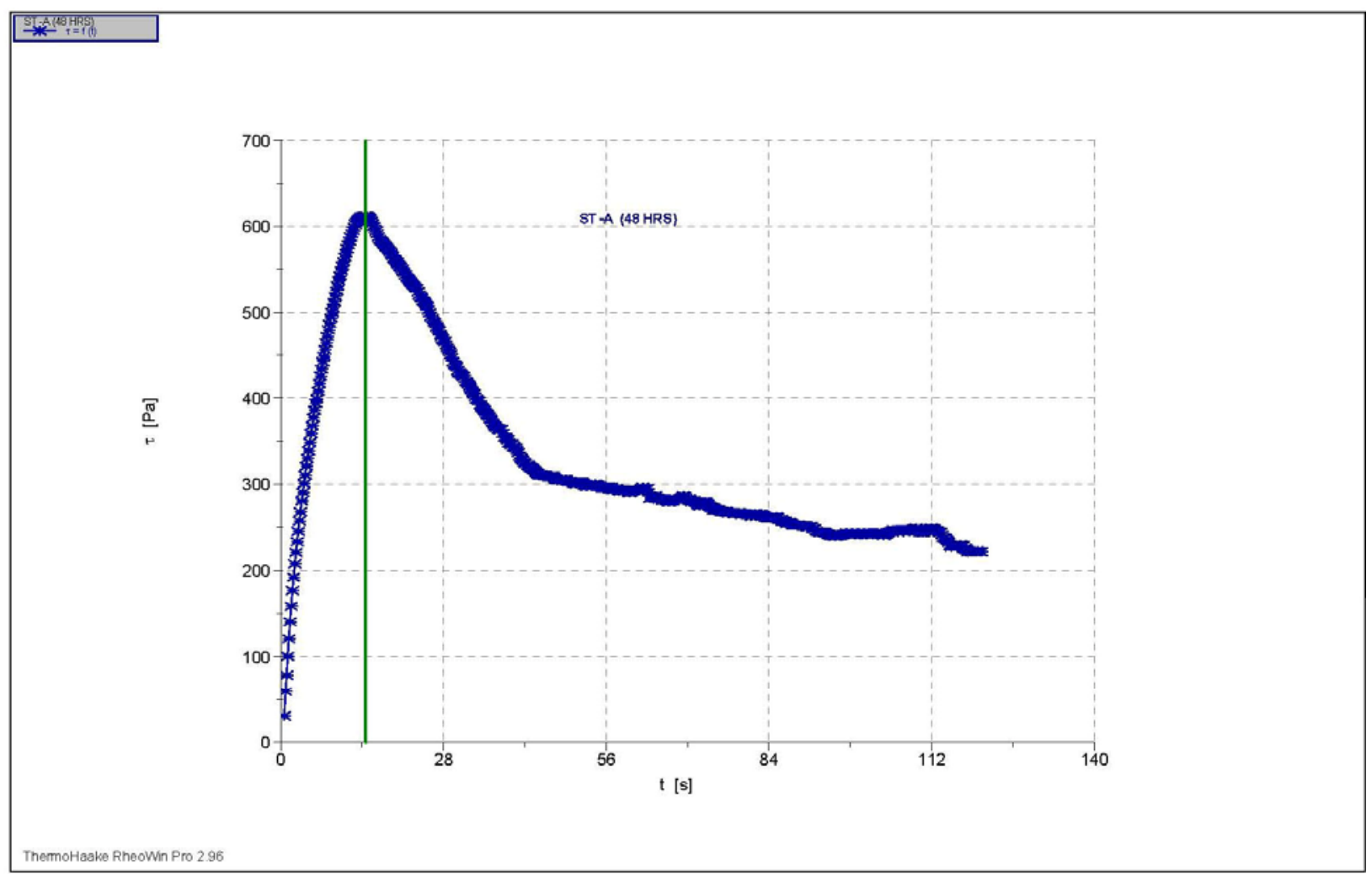

1: C:IRheologv Results $153019-M 121 S h e a r$ Strength $1.6 \times 1.6 \mathrm{~cm}$ VanelST -A (48 HRS).rwd Company / Operator: PNNL / MARIA LUNA

Date / Time / Version: 05.03.2009 / 15:58:51 PM / RheoWin Pro 296

Substance / Sample no: ST -A (48 HRS) / ST -A (48 HRS)

Curve discussion: Greatest value $\mathrm{t}[\mathrm{s}] 14.60 \tau[\mathrm{Pa}] 612.4$ 
ThermoHaake RheoWin 3/9/2009 / 12:54 PM

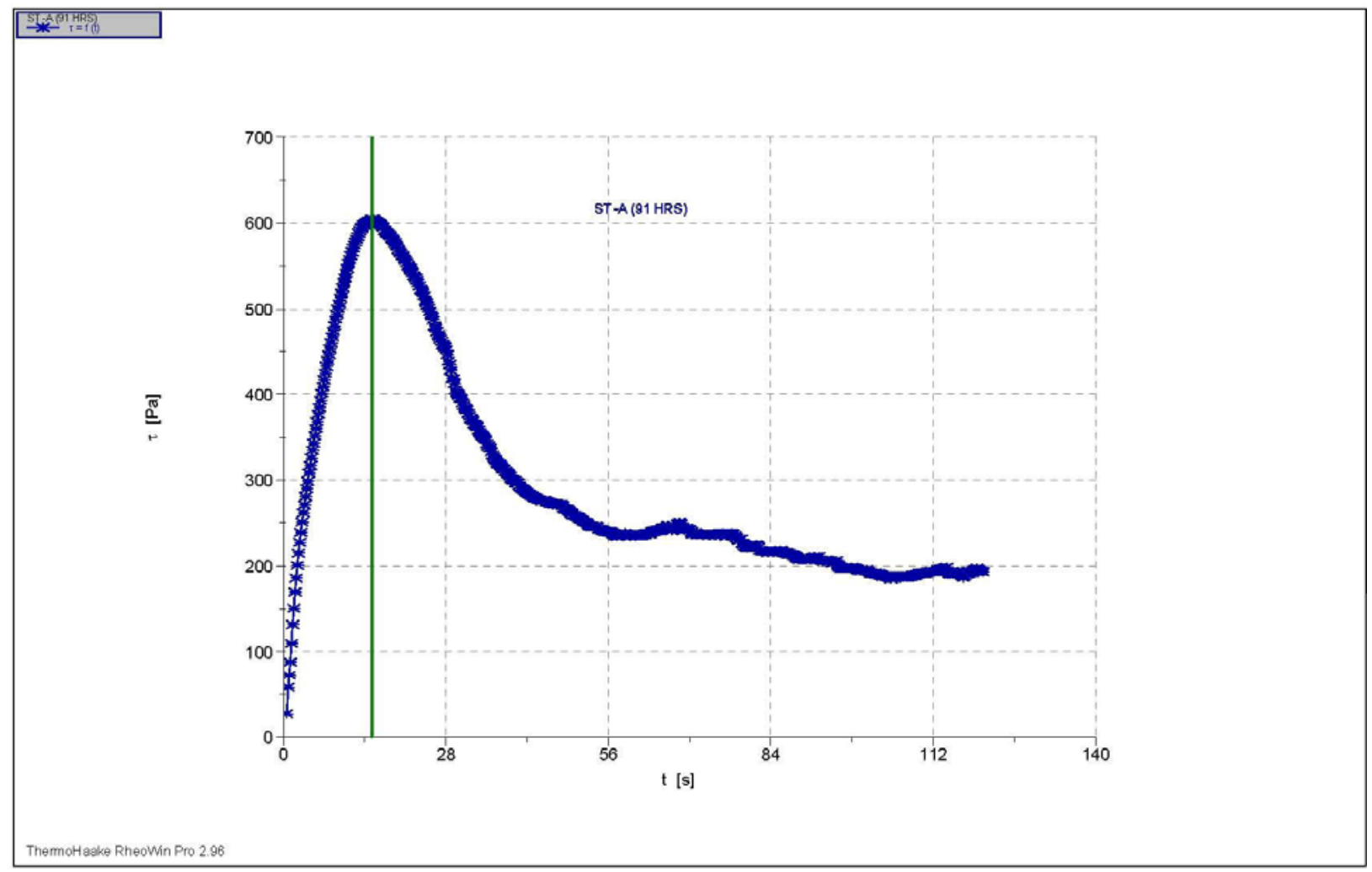

1: C:IRheology Results $153019-M 121$ Shear Strength $1.6 \times 1.6 \mathrm{~cm}$ VanelST -A (91 HRS).rwd Company / Operator: PNNL / MARIA LUNA

Date / Time / Version: 09.03.2009 / 12:47:34 PM / RheoWin Pro 296

Substance / Sample no: ST -A (91 HRS) / ST -A (91 HRS)

Curve discussion: Greatest value $\mathrm{t}[\mathrm{s}] 15.22 \tau[\mathrm{Pa}] 604.3$ 


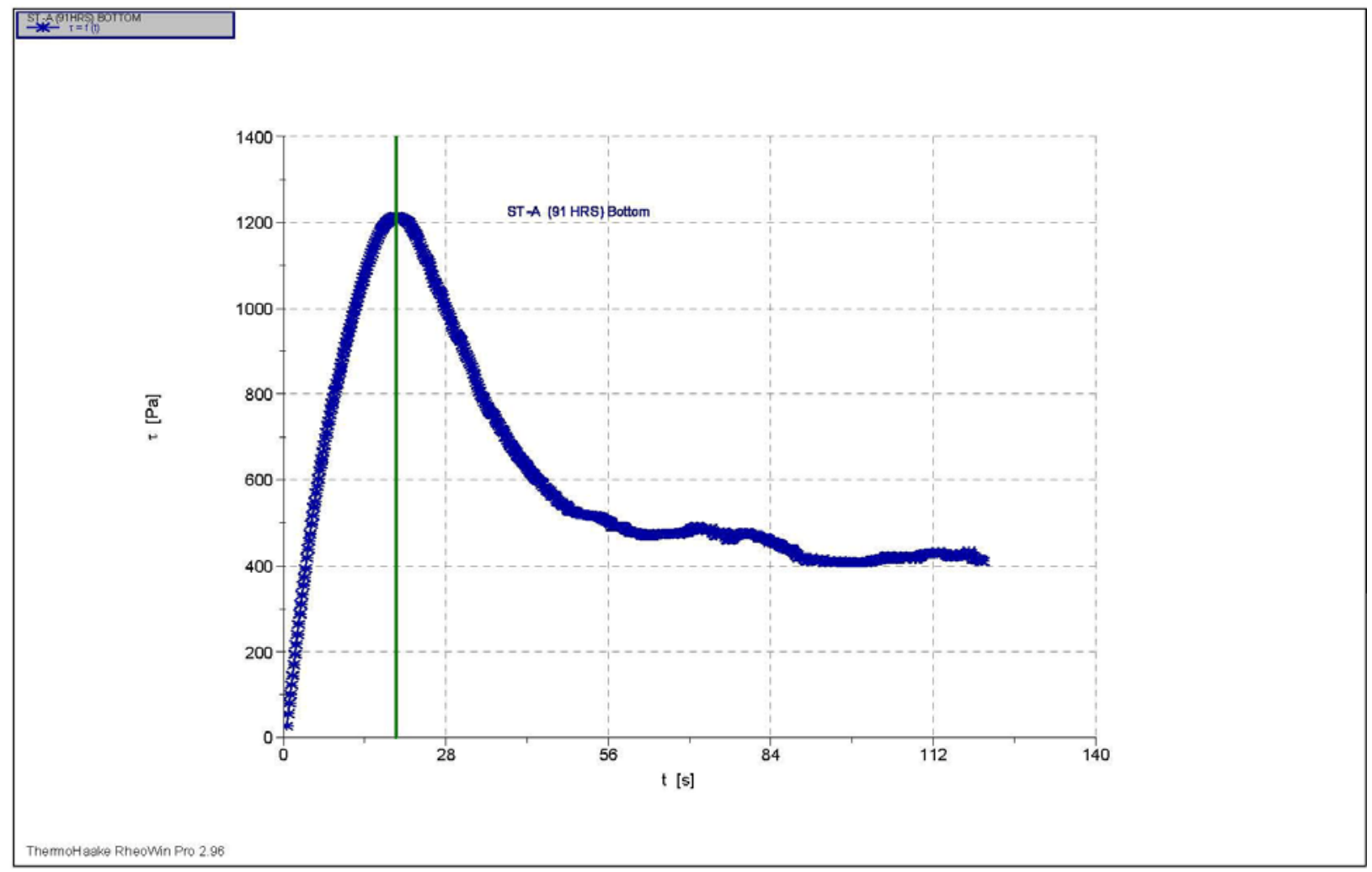

1: C:IRheologv Results IK -Basin IShear Strength (vane)IST -A (91HRS) BOTTOM.rwd Company / Operator: PNNL / MARIA LUNA

Date / Time / Version: 09.03.2009 / 15:11:11 PM / RheoWin Pro 296

Substance / Sample no: ST-A (91HRS) BOTTOM / ST-A (91HRS) BOTTOM

Curve discussion: Greatest value $\mathrm{t}[\mathrm{s}] 19.40 \tau[\mathrm{Pa}] 1214$. 
ThermoHaake RheoWin 3/3/2009 / 1:15 PM

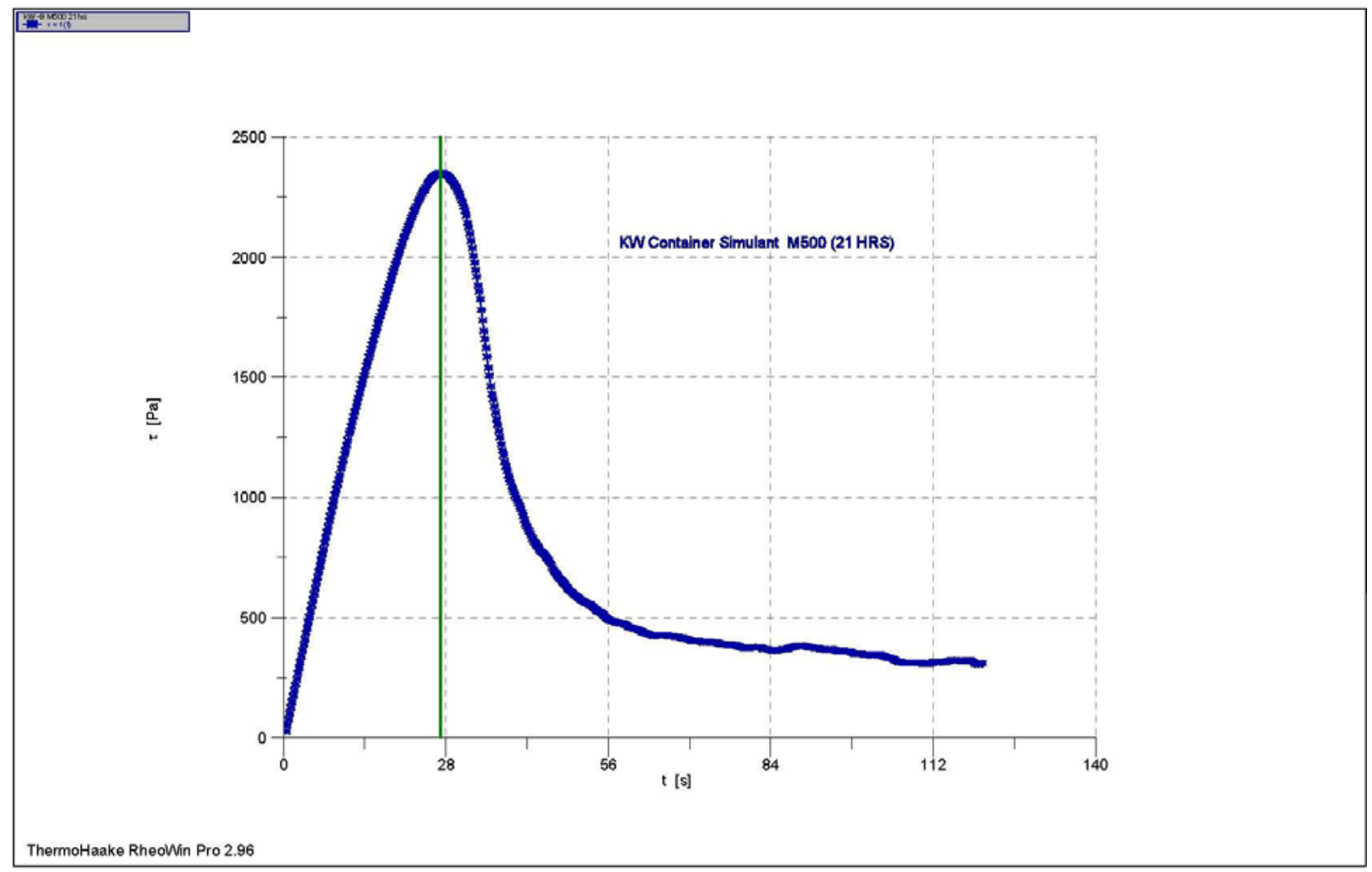

1: C:IRheologv Results 153019 -M12IShear Strength 1.6 X $1.6 \mathrm{~cm}$ Vane $\mid \mathrm{KW}-\mathrm{B}$ M500 21 hrs.rwd Company / Operator: PNNL / MARIA LUNA

Date / Time / Version: 03.03.2009 / 13:09:22 PM / RheoWin Pro 296

Substance / Sample no: $090303 \mathrm{KW}$ Container Simulant 21 hrs / KW-B M500 21 hrs

Curve discussion: Greatest value t $[\mathrm{s}] 27.08 \tau[\mathrm{Pa}] 2350$. 


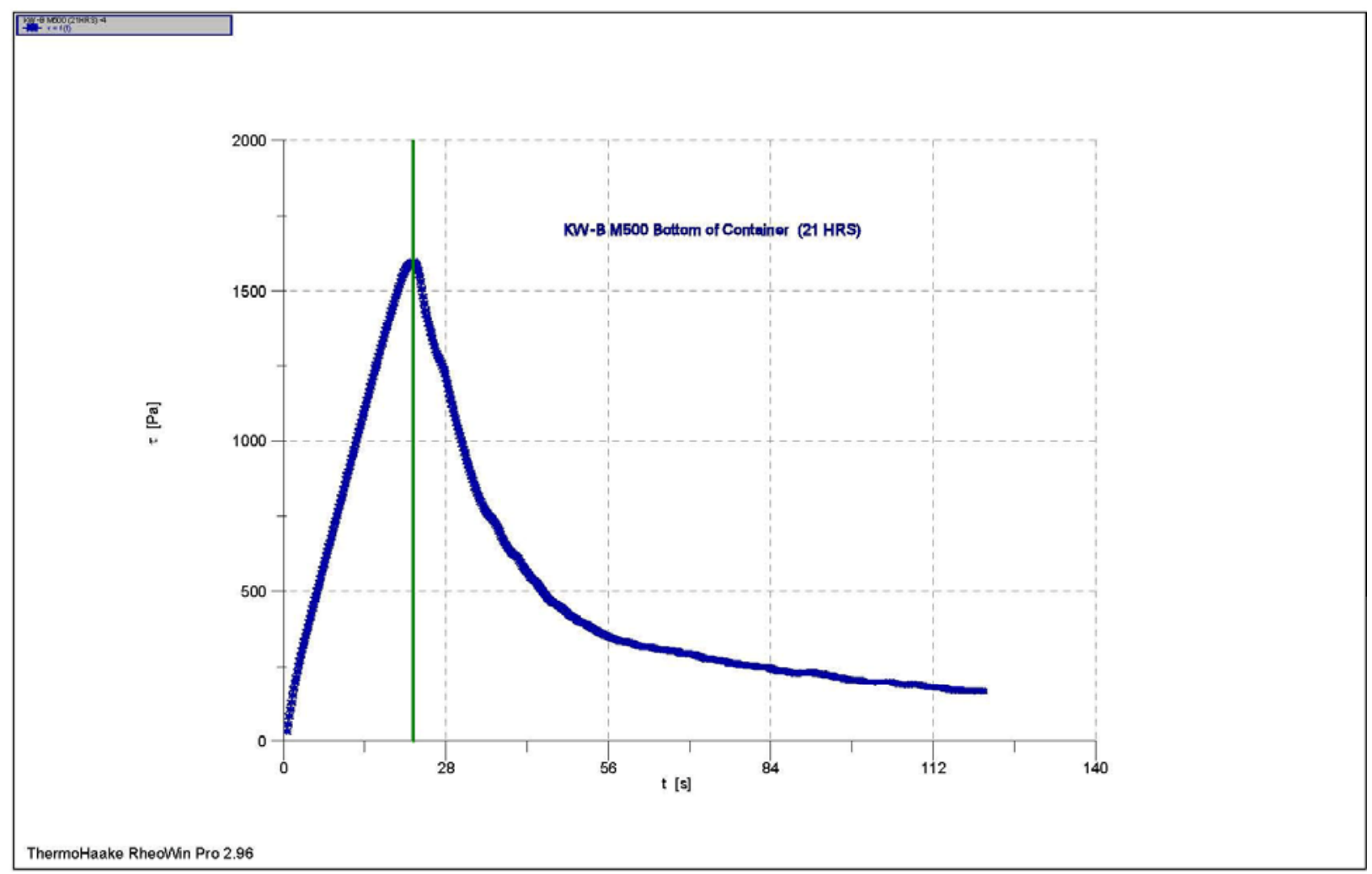

1: C:IRheology Results 153019 -M12IShear Strength 1.6 X $1.6 \mathrm{~cm}$ VanelKW-B M500 (21HRS) -4.rwd Company / Operator: PNNL / MARIA LUNA

Date / Time / Version: 05.03.2009 / 10:44:15 AM / RheoWin Pro 296

Substance / Sample no: KW-B M500 (21 HRS) -4 / KW-B M500 (21HRS) -4

Curve discussion: Greatest value $\mathrm{t}[\mathrm{s}] 22.38 \tau[\mathrm{Pa}] 1597$. 
ThermoHaake RheoWin 3/6/2009 / 12:04 PM

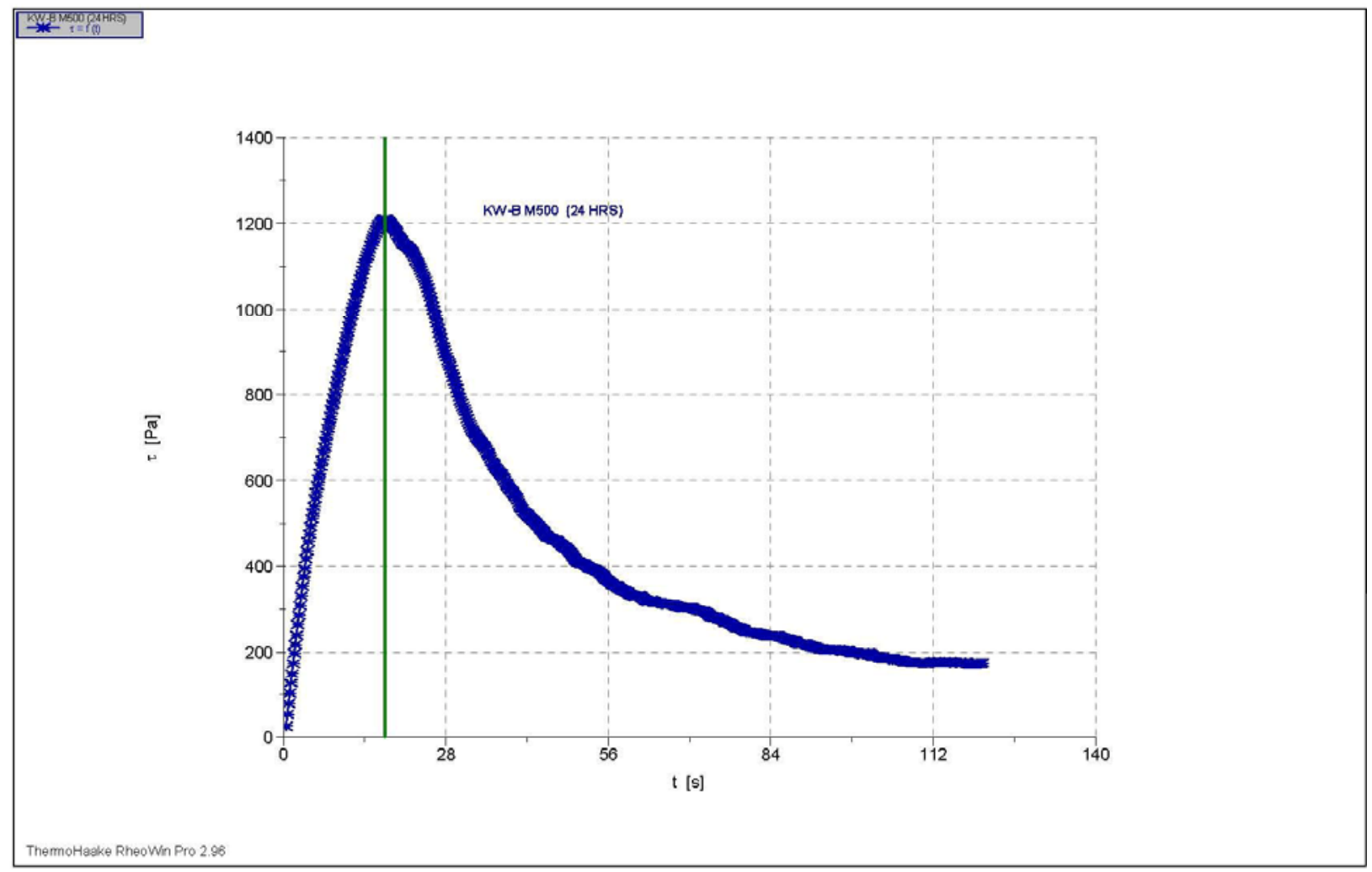

1: C:IRheology Results \K-Basin IShear Strength (vane)\KW-B M500 (24HRS).rwd Company / Operator: PNNL / MARIA LUNA

Date / Time / Version: 06.03.2009 / 11:59:28 AM / RheoWin Pro 296

Substance / Sample no: KW-B M500 (24HRS) / KW-B M500 (24HRS)

Curve discussion: Greatest value t [s] $17.49 \tau$ [Pa] 1209. 
ThermoHaake RheoWin 3/11/2009/3:43 PM

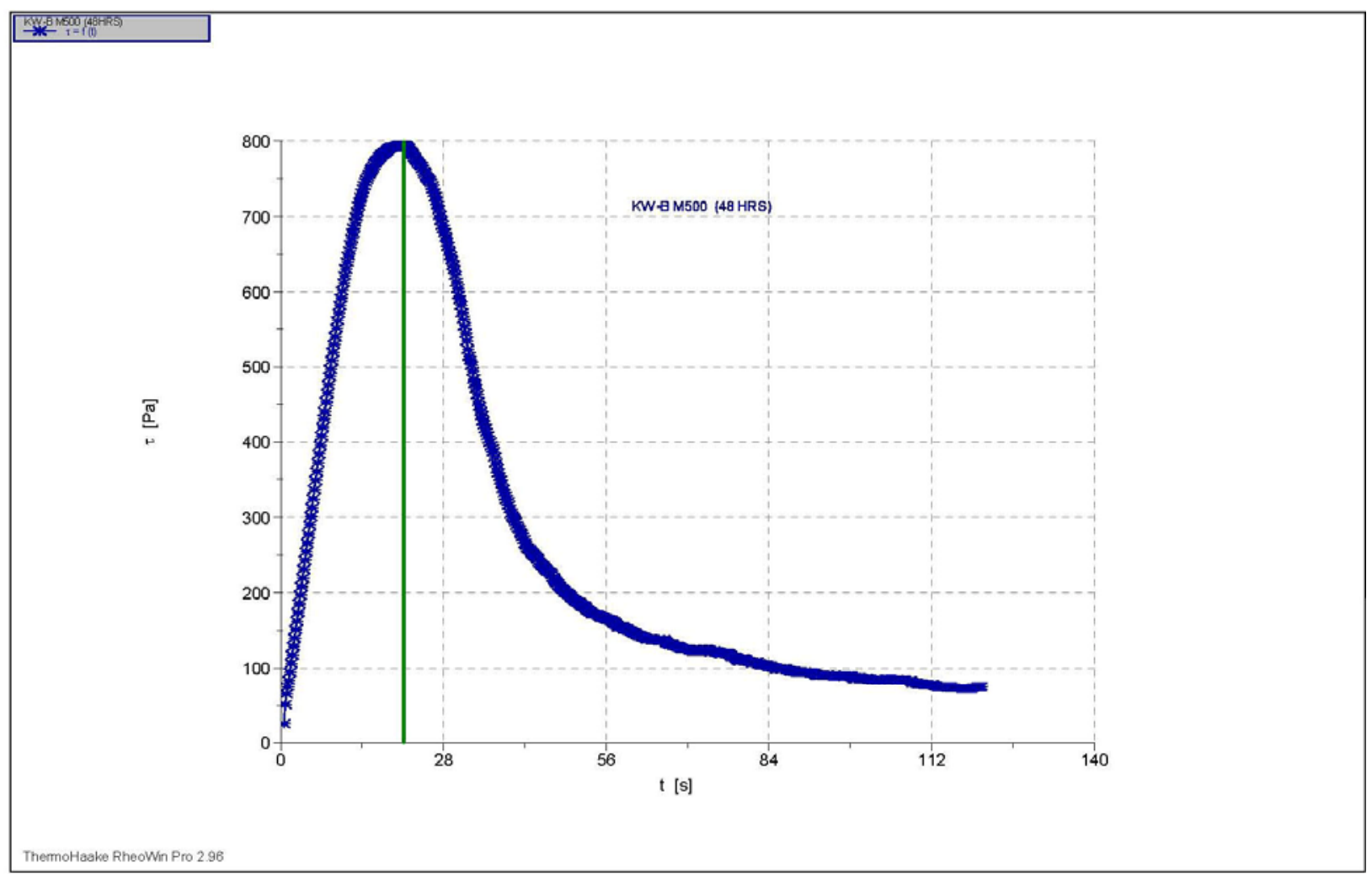

1: C:IRheologv Results \K-Basin \Shear Strength (vane)|KW-B M500 (48HRS).rwd Company / Operator: PNNL / MARIA LUNA

Date / Time / Version: 11.03.2009 / 15:34:44 PM / RheoWin Pro 296

Substance / Sample no: KW-B M500 (48HRS) / KW-B M500 (48HRS)

Curve discussion: Greatest value $\mathrm{t}[\mathrm{s}] 21.19 \tau[\mathrm{Pa}] 797.4$ 


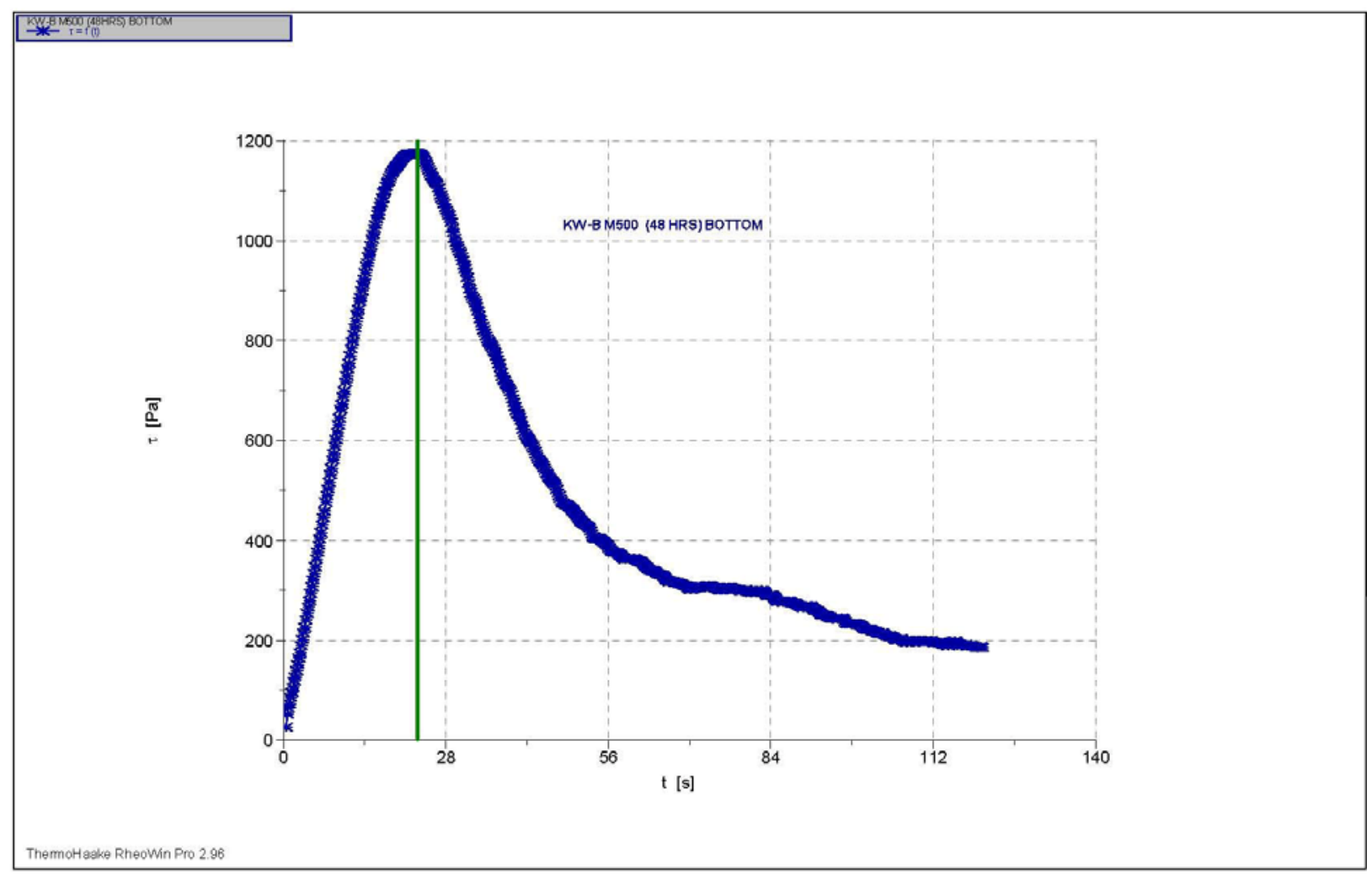

1: C:IRheology Results \K-Basin IShear Strength (vane)\KW-B M500 (48HRS) BOTTOM.rwd Company / Operator: PNNL / MARIA LUNA

Date / Time / Version: 11.03.2009 / 15:38:25 PM / RheoWin Pro 296

Substance / Sample no: KW-B M500 (48HRS) BOTTOM / KW-B M500 (48HRS) BOTTOM

Curve discussion: Greatest value t [s] $23.12 \tau$ [Pa] 1174. 
ThermoHaake RheoWin 3/16/2009 / 9:05 AM

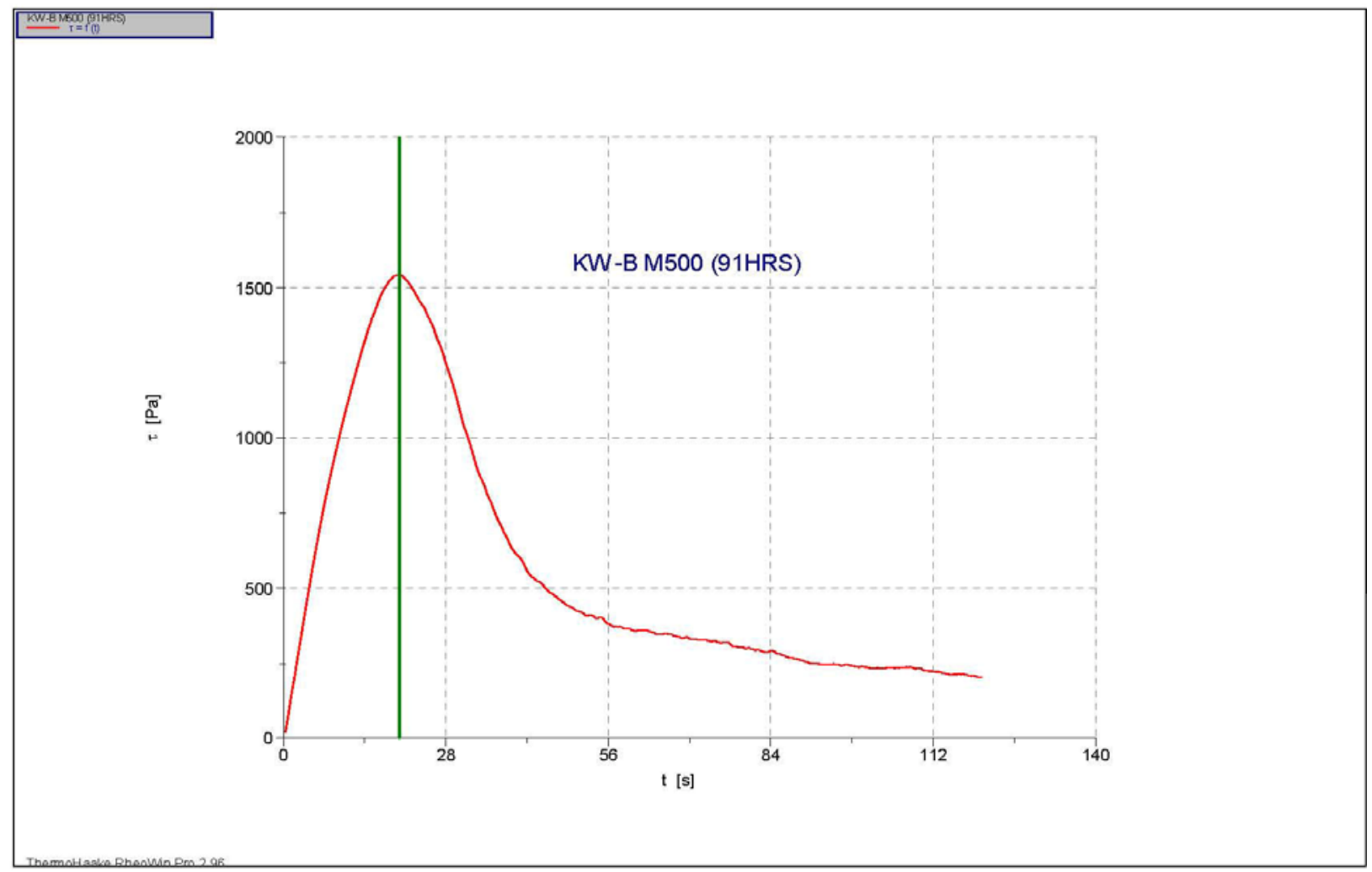

1: C:IRheologv Results \K-Basin IShear Strength (vane)\KW-B M500 (91HRS).rwd

Company / Operator: PNNL / MARIA LUNA

Date / Time / Version: 16.03.2009 / 8:58:04 AM / RheoWin Pro 296

Substance / Sample no: KW-B M500 (91 HRS) / KW-B M500 (91 HRS)

Curve discussion: Greatest value t [s] $19.99 \tau[\mathrm{Pa}] 1543$. 
ThermoHaake RheoWin 3/16/2009 / 9:07 AM

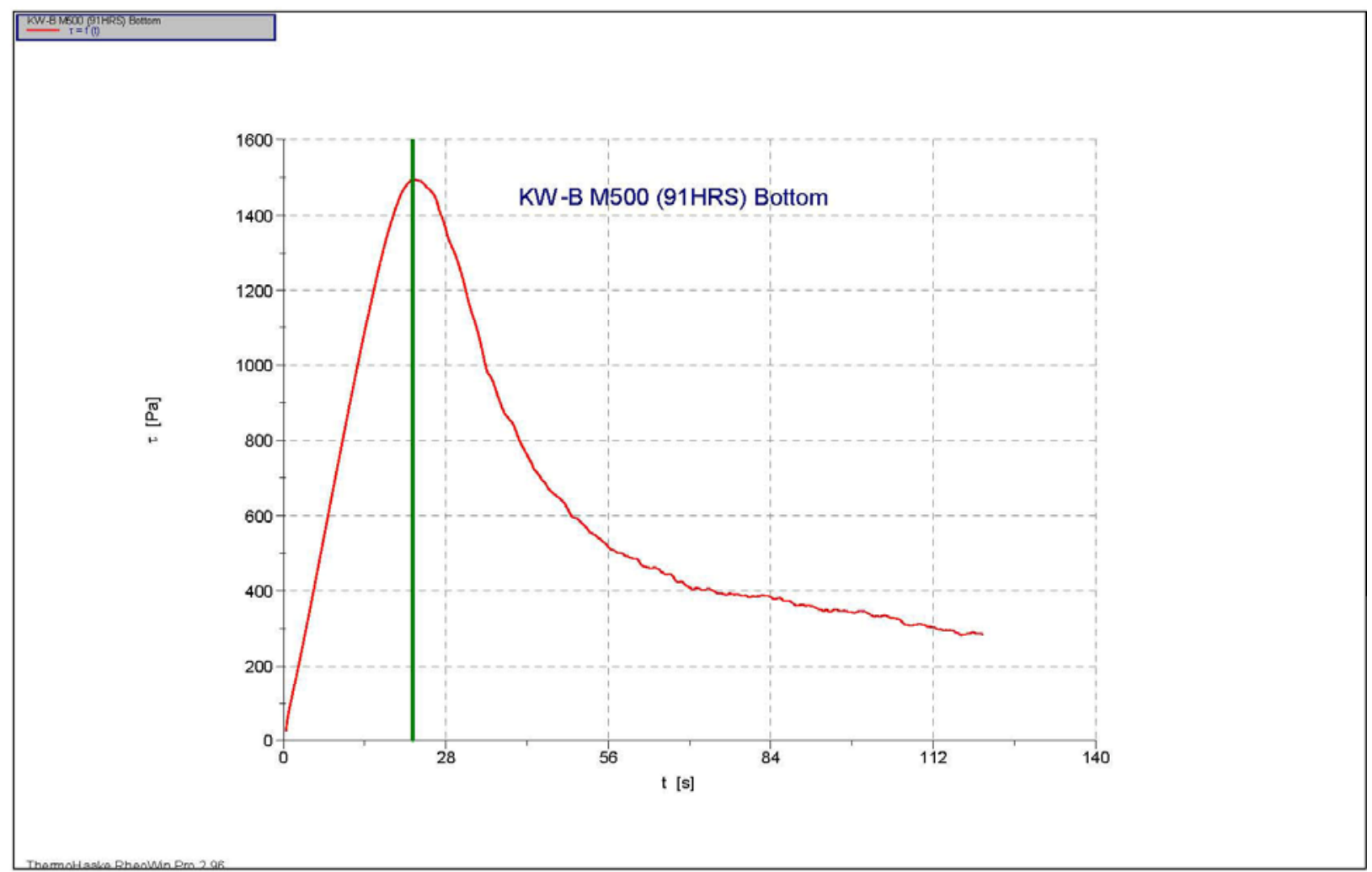

1: C:\Rheologv Results \K-Basin IShear Strength (vane)\KW-B M500 (91HRS) Bottom.rwd Company / Operator: PNNL / MARIA LUNA

Date / Time / Version: 16.03.2009 / 9:02:05 AM / RheoWin Pro 296

Substance / Sample no: KW-B M500 (91 HRS) Bottom / KW-B M500 (91 HRS) Bottom

Curve discussion: Greatest value t [s] $22.28 \tau$ [Pa] 1495. 
ThermoHaake RheoWin 3/4/2009 / 1:16 PM

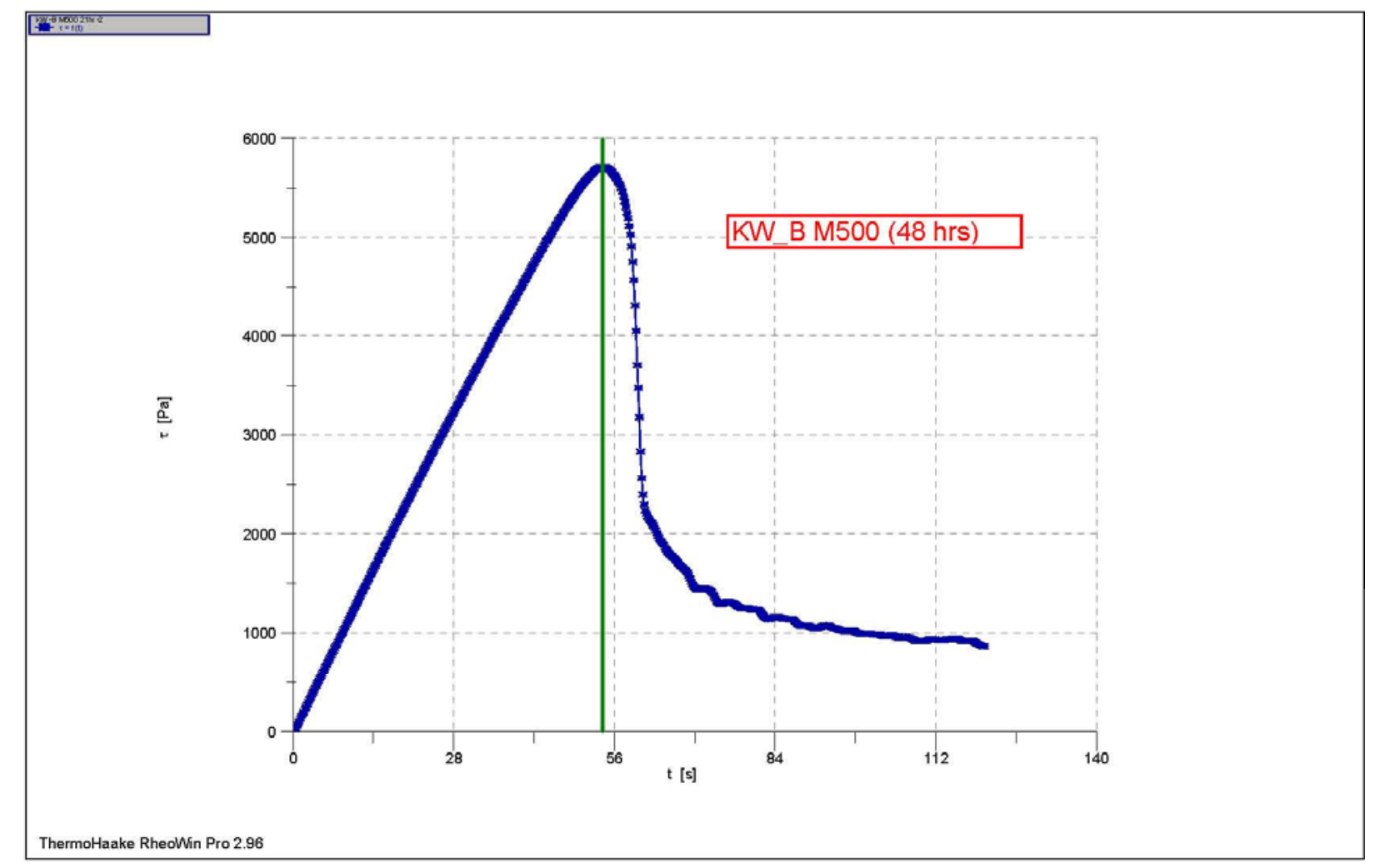

1: C:IRheologv ResultsI53019-M12IShear Strength 1.6 X $1.6 \mathrm{~cm}$ VanelKW-B M500 21hr-2.rwd Company / Operator: PNNL / MARIA LUNA

Date / Time / Version: 04.03.2009 / 13:11:58 PM / RheoWin Pro 296

Substance / Sample no: KW-B M500 $21 \mathrm{hr}-2$ / KW-B M500 21hr-2

Curve discussion: Greatest value $\mathrm{t}[\mathrm{s}] 53.96 \tau[\mathrm{Pa}] 5715$.

C. 14 

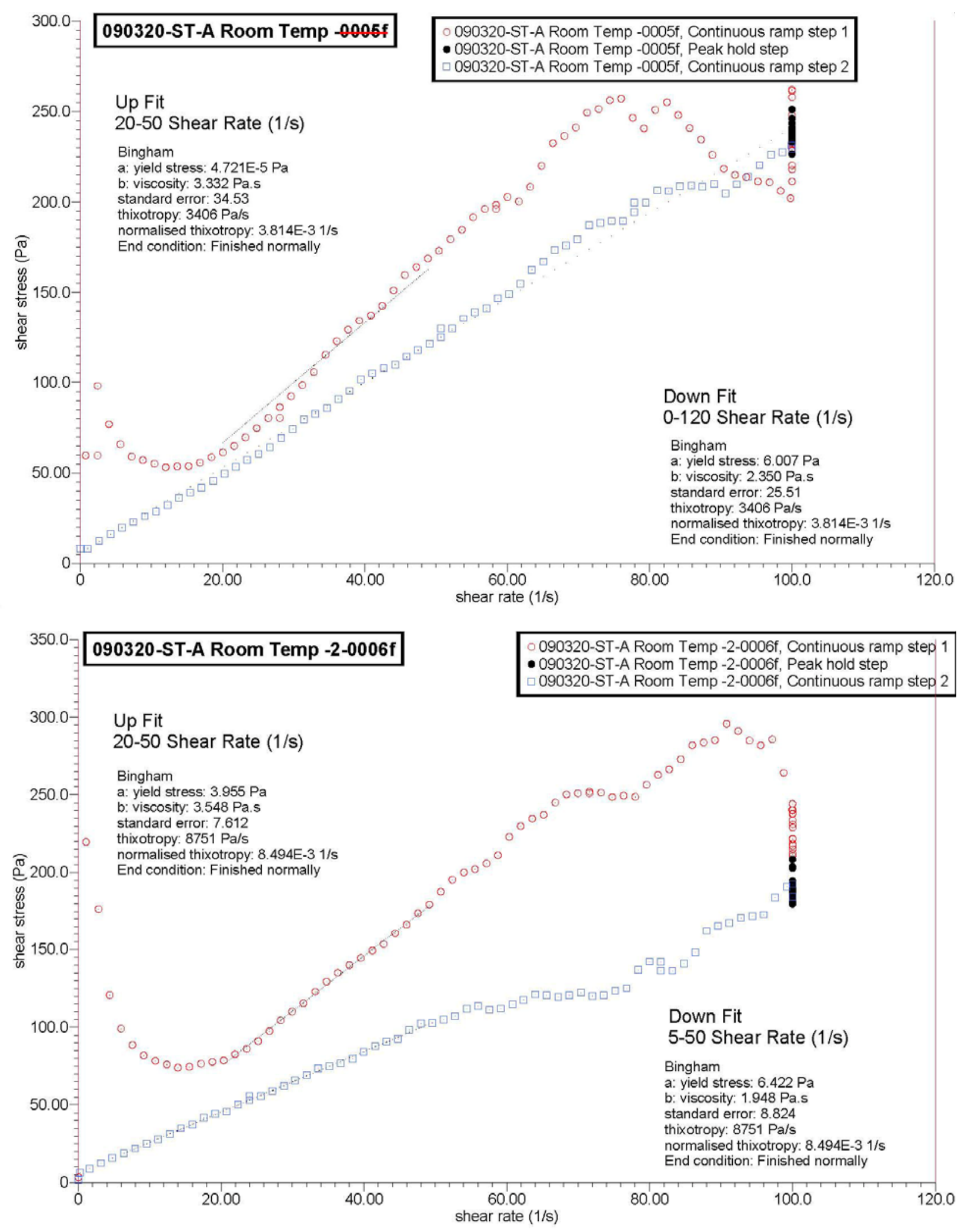

C. 15 


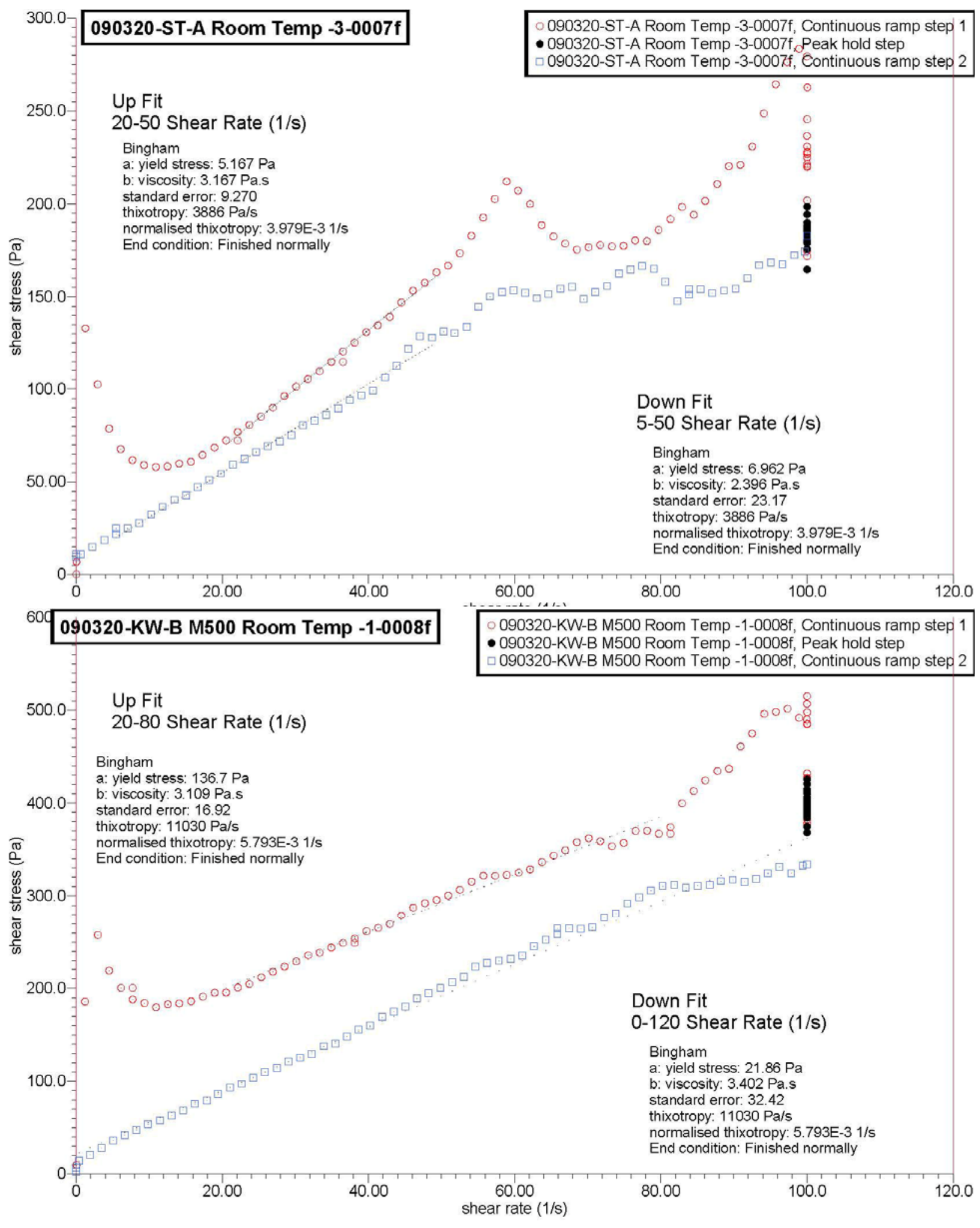

C. 16 

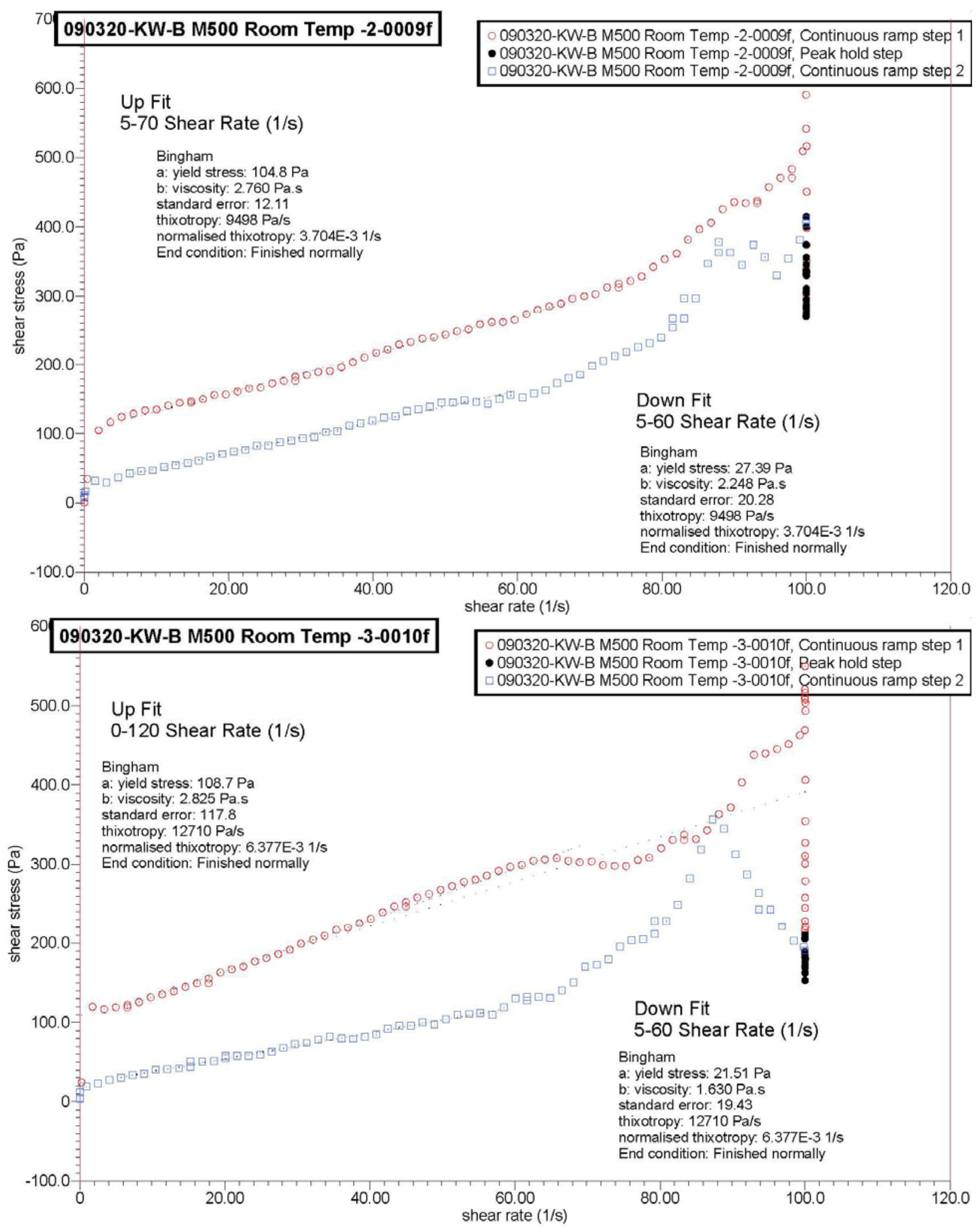

C. 17 

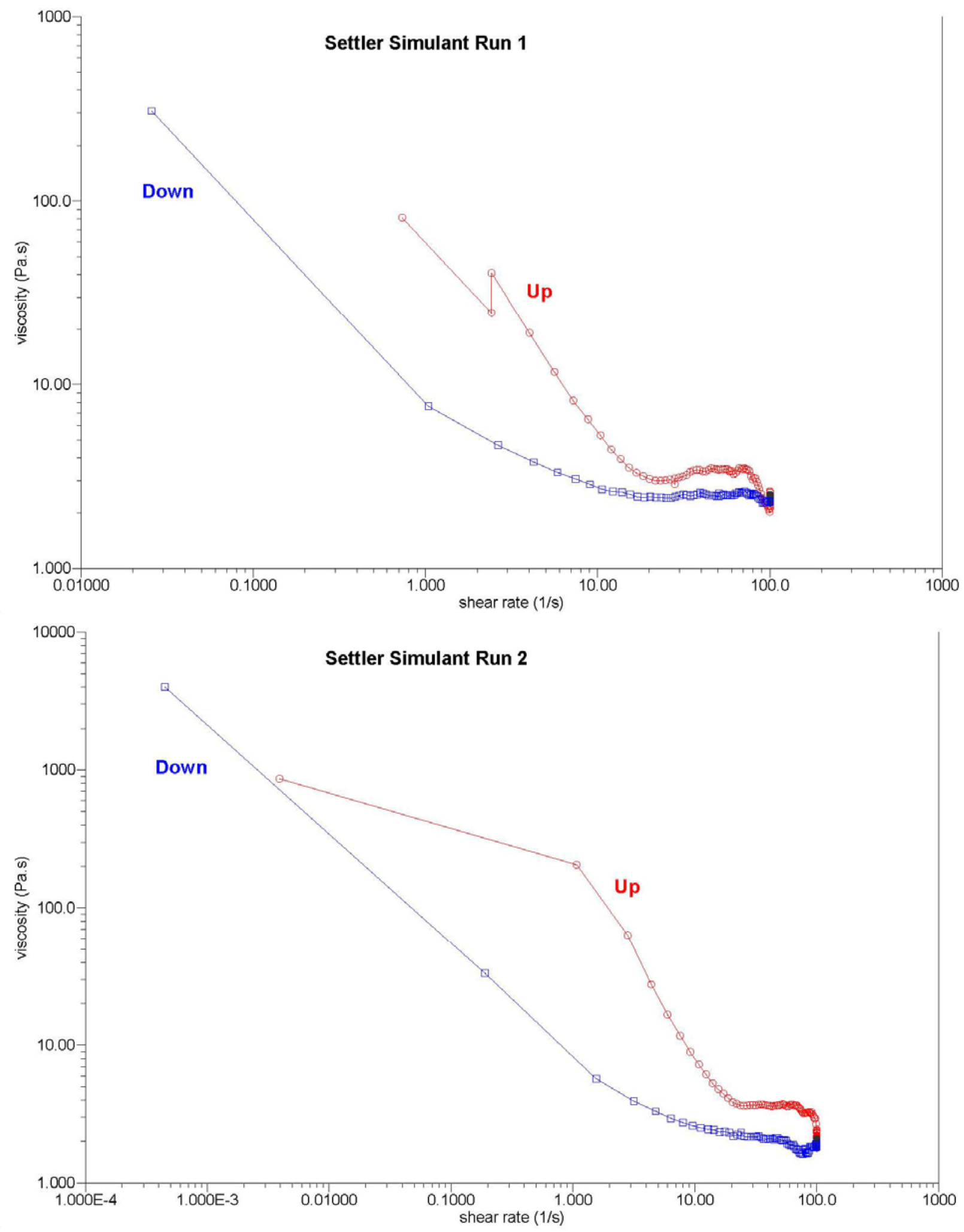

C. 18 

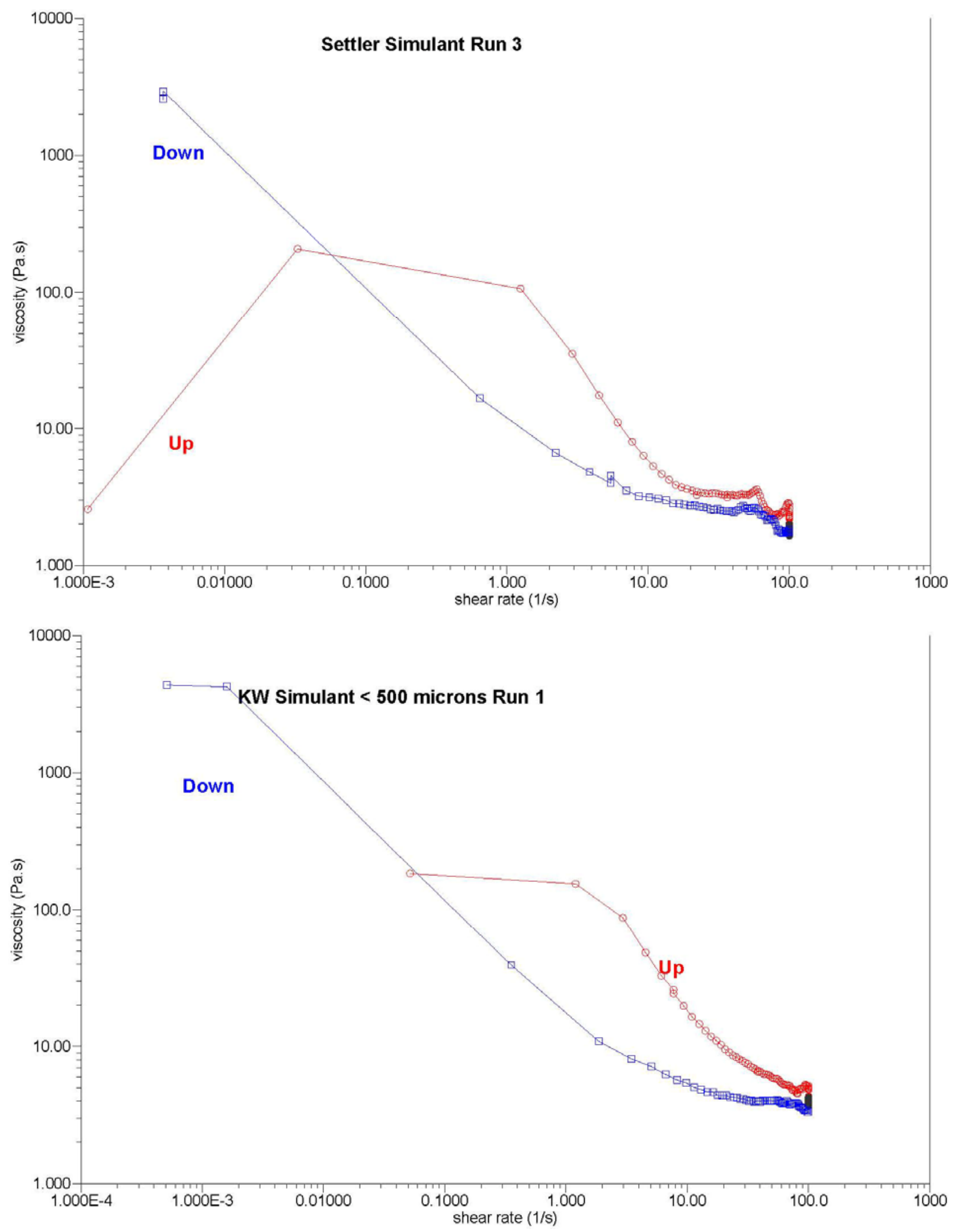

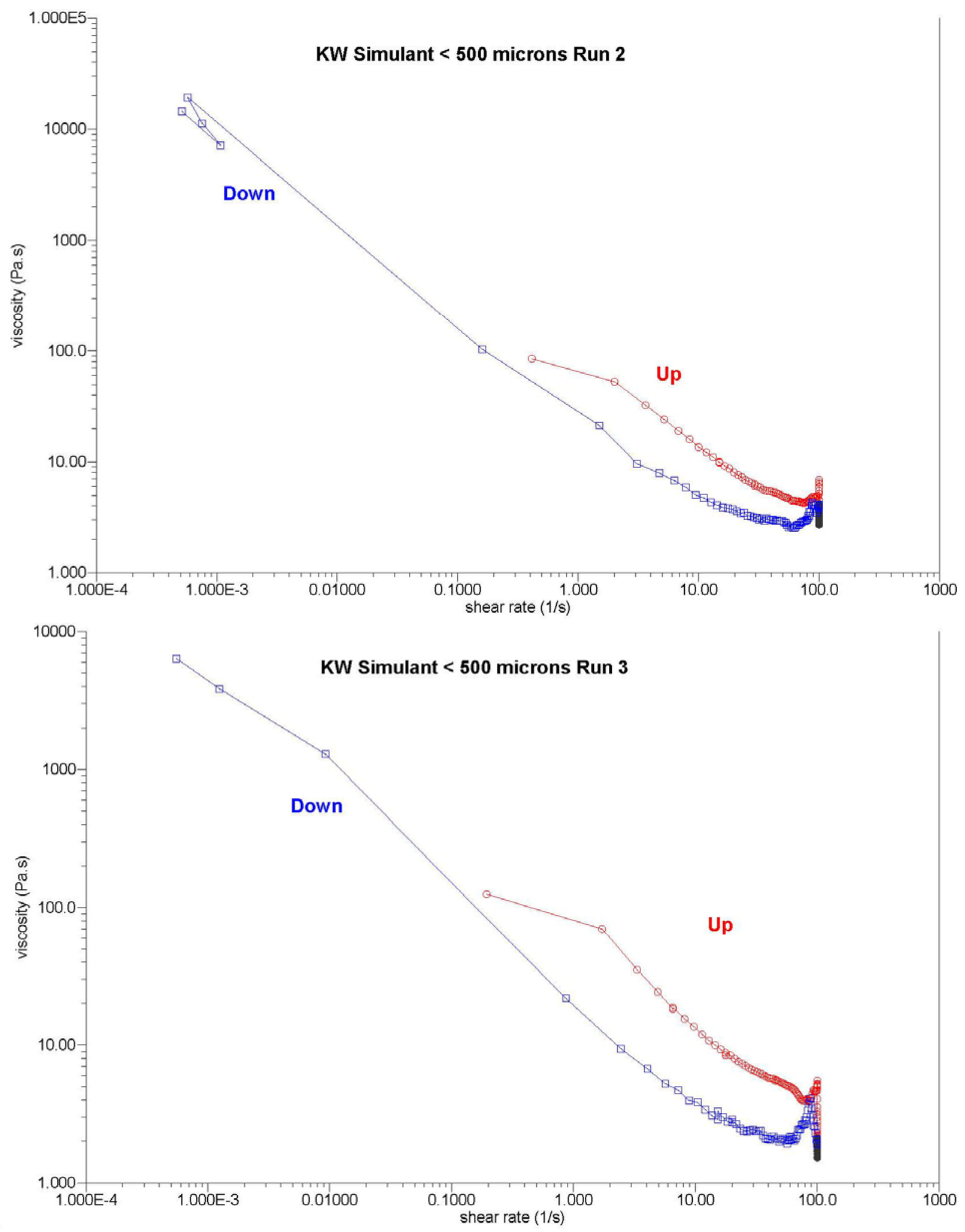